University of Louisville

ThinkIR: The University of Louisville's Institutional Repository

Electronic Theses and Dissertations

9-1947

\title{
Water and water vapor barriers for structural plywood : II. core void fillers for structural plywood.
}

James Van Dyck Fear

University of Louisville

Follow this and additional works at: https://ir.library.louisville.edu/etd

Part of the Chemical Engineering Commons

\section{Recommended Citation}

Fear, James Van Dyck, "Water and water vapor barriers for structural plywood : Il. core void fillers for structural plywood." (1947). Electronic Theses and Dissertations. Paper 1933.

https://doi.org/10.18297/etd/1933

This Master's Thesis is brought to you for free and open access by ThinkIR: The University of Louisville's Institutional Repository. It has been accepted for inclusion in Electronic Theses and Dissertations by an authorized administrator of ThinkIR: The University of Louisville's Institutional Repository. This title appears here courtesy of the author, who has retained all other copyrights. For more information, please contact thinkir@louisville.edu. 


\title{
umrvest or coorerxh
}

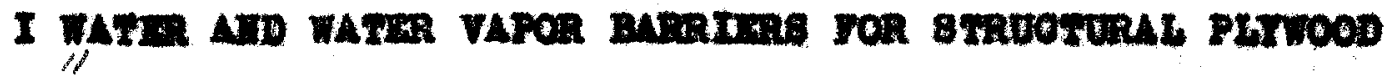

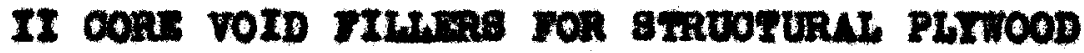

\author{
A mosia \\ subul thed to the moul ty \\ of the Gradunte Bohool \\ of the Dniveratty of Loulovilie \\ Is Partial maftilnont \\ of the Mequirements \\ Lor the Begree of
}

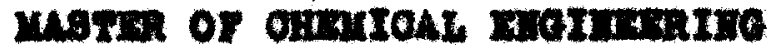

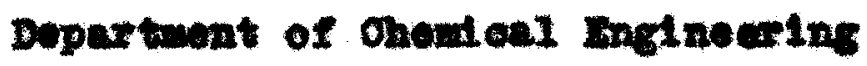

\author{
D \\ James Van Dyol your \\ 1947
}




\section{UHE UNWvessir LIBRARIES}

This PDF document is a scanned copy of a paper manuscript housed in the University of Louisville (UofL) Libraries. The quality of this reproduction is greatly dependent upon the condition of the original paper copy. Indistinct print and poor quality illustrations are a direct reflection of the quality of materials that are available for scanning. The UofL Libraries greatly appreciates any better copies that can be made available for replacement scans. 


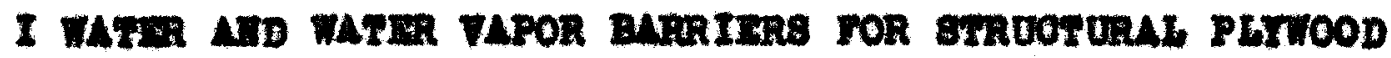

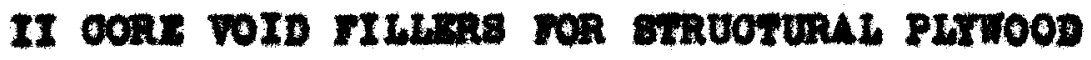

\author{
Janes Tou Brok roas
}

\title{
Approved by the bualning Comblt toe
}

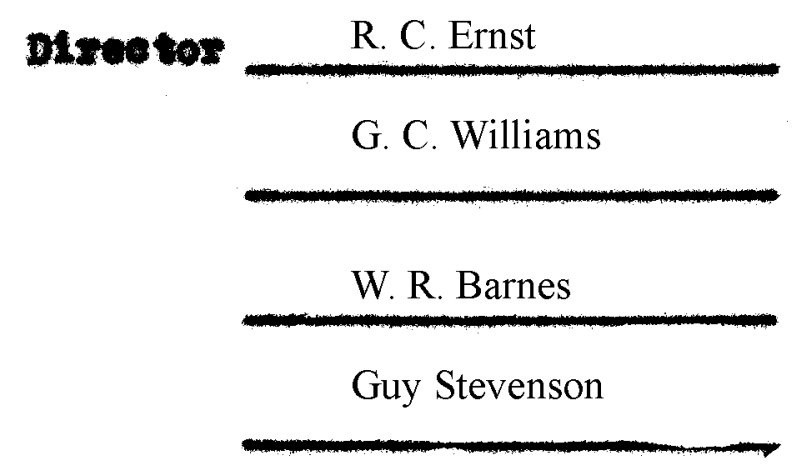

eptomber, 1947 
A K I 
The arther wiches to coknowledge

the kind esolstanoe and helpful guidanoe

of D. R. O. Erast and U. V. R. Barnes

whe elreoted this researoh. 
AB I A A 
Th1. thosle presents the resulte of an Investigation son-

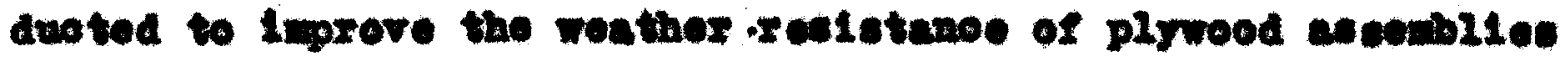

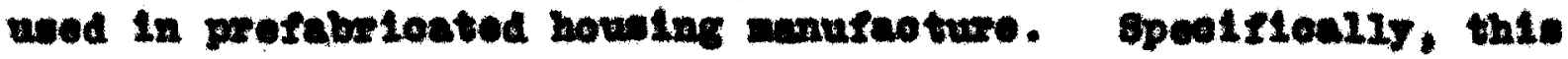

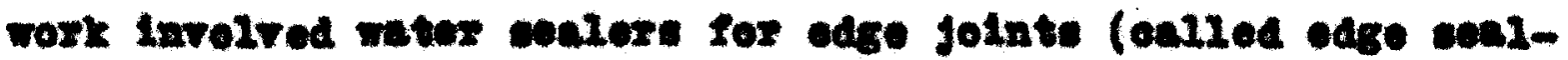
ora). the provent1on of ourfeoe tranefor of water vapos through

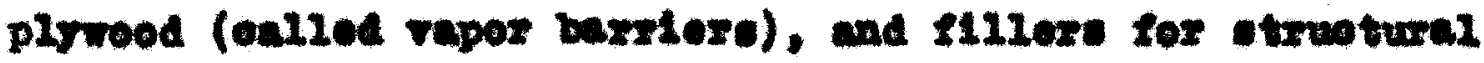
defeets in the wook (onlled oore vold flliers).

Twe edget cenlers for plywed were doveloped thet were eonstdered suoseveful in sesteting vater permostion. One wa a quidek dxying palnt formuiated by the adition of 30 per eont.

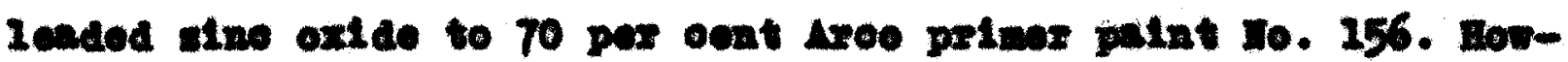
cres, a botter but alowes enting coalor was found in the we of two eonte of 40 per ecat 2 eaded gine oxtes and 60 pex eent glyoerri phomelate remidh.

Two vepor barfiere wexe doveloped that wexe swoeseful in combetilng woleture condenention in the atud opaoe of extertos wall ascobiles. One of thoes was an almbinum-glisonite paint. The other was on elenimun foll bonded to the plywoed. Ilthes would sedvoe the woleture diefunton through wood in exoses of 95 pex oent. A wothod is presented thet would alk the uno of aluninw loil coonendoslly leadble.

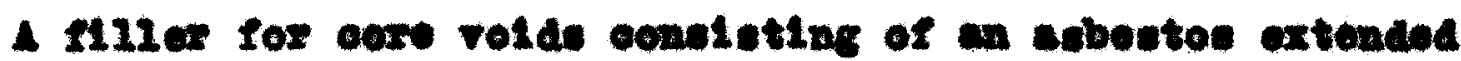

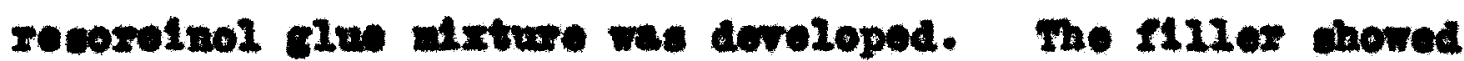

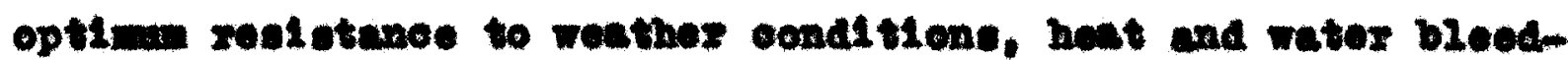
Ing, and had an exeellont pot IIfo. 
Let of trbles ...................... v Liet of mgures ...................... v1

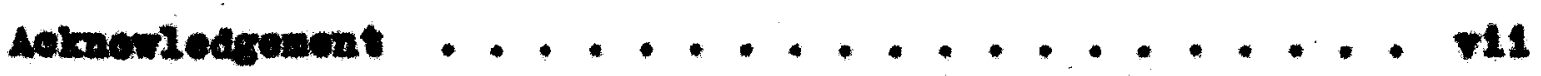

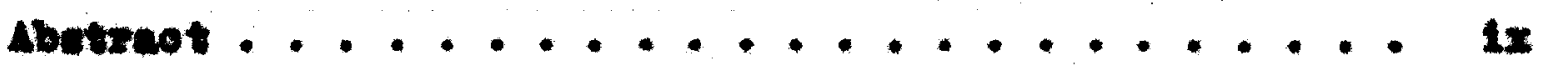
1. Wol whwe and Vepor Barriex for struotwel plyood Introduation ................... 1 Hinterteal ................... 4 moorotien ................... 12 Ixperimantal ................. 24

4. Dater Imoreten tost of meter Eurriare . . 26

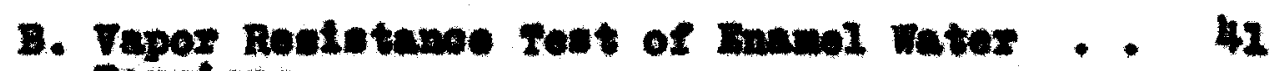
Darriest

0. Water Imoreton Tout of Water Barriera . 51

D. Evaluation of Water Vepor Barriors . . . 56

gromery and Oonalwaloas ............ 70

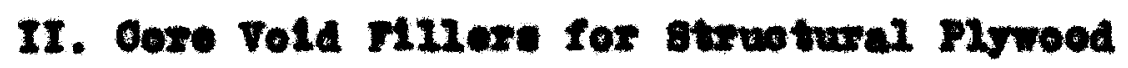

Intreduet1on .................. 73

Hietorteal ................... 75

moeretioal ................... 77

mpontmental ................... do

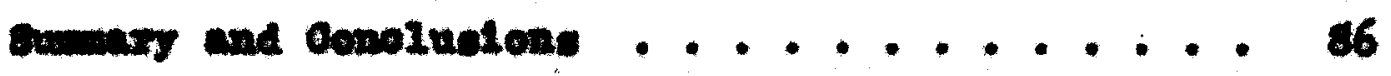

L toratruse atted .................... d8 


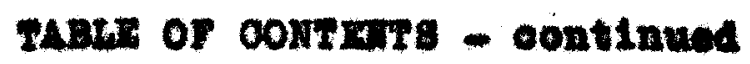

Pase

Loknowl edinent . . . . . . . . . . . . . . 98

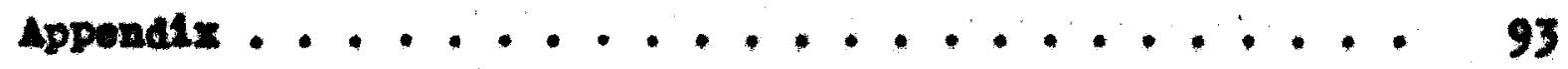

Eample Caloulations ....................... 94

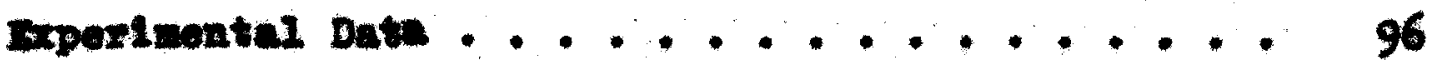

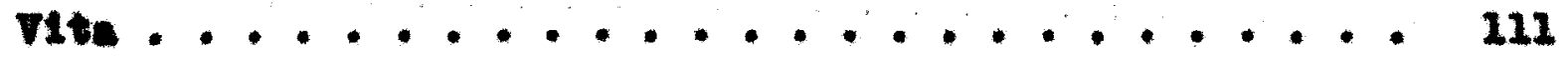




\section{LIBS or TABurs}

Table

I. Composition of Edge Ganlare Ueed In a Wator Inerelon reet

II. Wol oture Plokup of stgo soaled wood ....... 32

III. Wolotume Plokv Rotelnoe of nage sealod Wood Daring a soven bay parting Ported...... 33

IV. Pos oont Iffootivenese of Edge seazere Agelnot Vates ..................... 34

7. Dompostion of page sealex. Ueed in a Matox vapor rest.................. 43

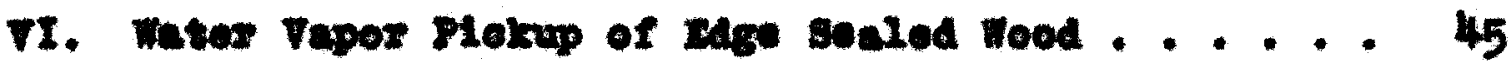

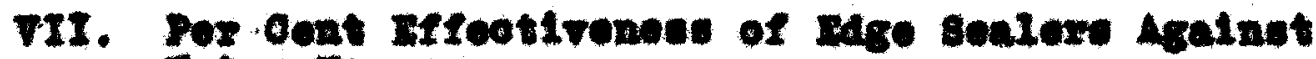

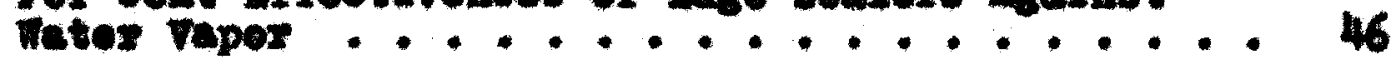

III. Composttien and Rosults of samples Teated to Invontigte vepor hostintanoe of Paraffin soale. . 49

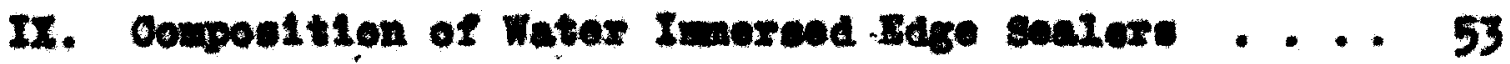

x. Caln In Wolstrure Oontent of Edge soaled wood . . . 54

II. Pex Cont Iffeotiveness of sample Bdge sealer. . 54

XII. Coupoedt1 on of sauple Vapox Barriere reated . . . 64

XIII. Uoleture Difrued Through Vapex Barrier gamles. . 65

IIT. Rate of whter Vapor phffuling Throuch Vapor Barriers.................. 66

xy. Por Oont Iffeotivenese of vapor Barriers . . . . 68

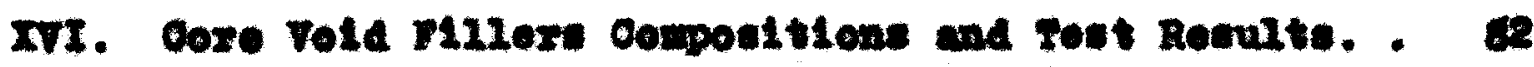




\section{LIST or 8 roung}

Insen

xta.

Bere

1.

Moletrux Plokup of Edge sealod wood

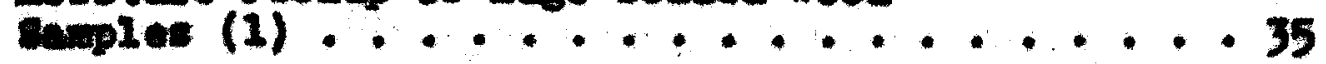

2. Wointure Plokw of Edge sealed wood

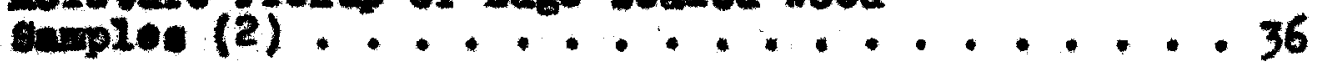

3. Hoteture Mokup of rage sealed wook

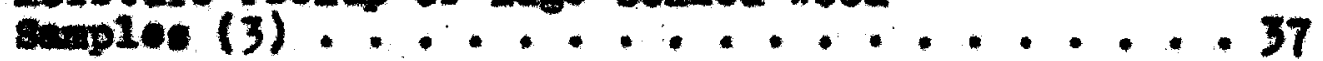

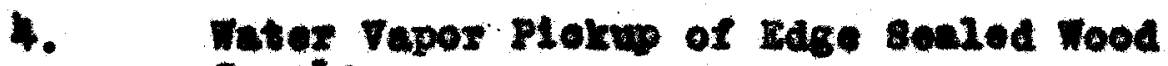

Bamplea................. 47

5. Guln in Voloture oontent of rese called

Tood saples ................. 55

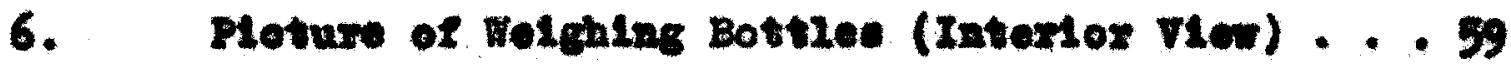

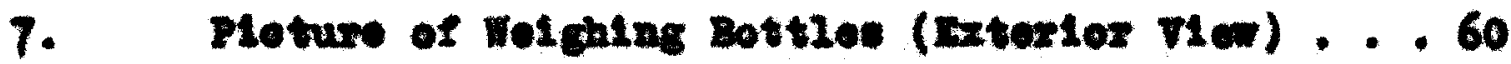

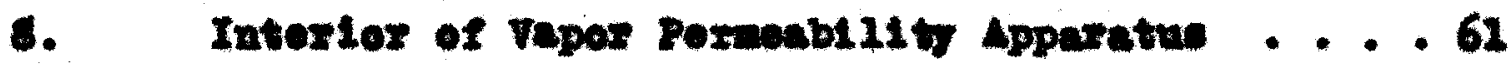

9. Vapor Pormobilit Apparatus Read Ior Operation. 62

10. Vaper Diffueton ourves (1)..........66

11. Tapar piervielon ourves (2)...........67 
I. 4 TER A ED UA TER VAPOR BARRIER日 TOR GRUOZURA P I 1000

\section{I}


Wass produotion of prefobrteated howes is a relatively new Industry in the Bulted states, coulng into prominomes with World Wax II as a colution for the houlng bbortage. Wany different construotional dosigne are uead by manufeoturers in prodvolng these howes. One manufaoturer use a oonter pole to oupport a wob of obalne whtoh form a lattloe oupport for sheot motel ides. Inother uese a Iarce wold into whioh oonorete is poured, and after the hounes have eet, the form is romored. Another makes eoveral otundard peokaged ualt penele of plywood whioh are sent to the houstng alte. It is with the laet trpe that this these is conoernod, as unforeseen probleme wore enoountored in the eneoseful oonetruotion of these panele.

One of these problowe was the suovestrul sealling of the unt wall coetione ageinet odgewles vater penotiration. In the wese production of the panely, sheets of plywood are bended to both ldes of a wooden framework. The panol reoelved a coat of white primer paint and after drylng, wae ready for anlpping. The finishing ooate of paint were applied after the house had been ereoted, and conevquently, the edges of the pariol did not recelve this further proteotion. The anufacturex felt that the edgen of the plymoed were not oufflolently proteoted from water by the application of one primer ooat of paint. The addition of wore than one opray coat of palnt in the plant did not lend Iteelf to the produotion sohodule. Furthor, the company did not know hom many additlonal oote would bo nooessary to provide adequate proteotion. 
4 ecoond problem enoovintered was in combating moleture condeneation in the otud apece of the panele while in wes. Varlou: Imrestigatere have ahown that rapor w111 oondones Indide tIghtly construoted well seotlon unlose en excellent rapor berrier is properiy inoorporated in the wall. In this oace the phonomenon was obwerved partieulariy in the window panele.

An Invertigation and reoommed colution of these two related problem is prenented in thls report and was a portion

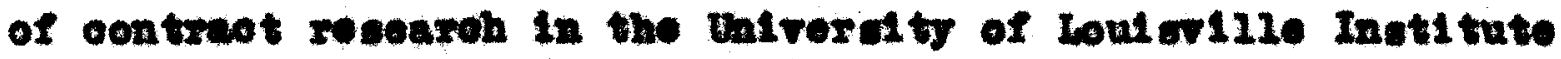
of Industrial Rosearoh. 
HI STORIOAL 


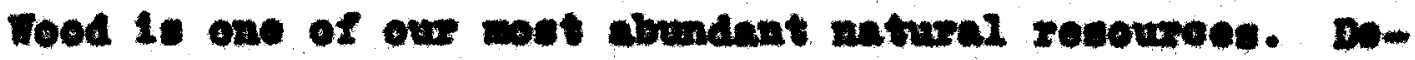

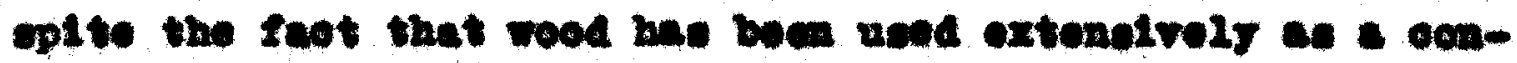

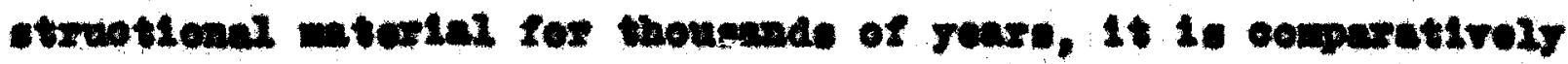

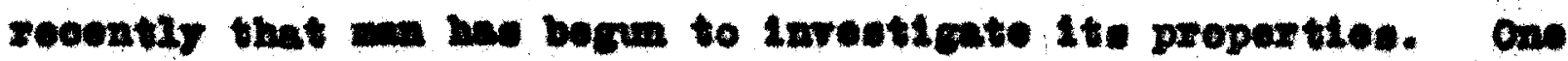
of the proporties of mood that zade to ite daterionstion 1

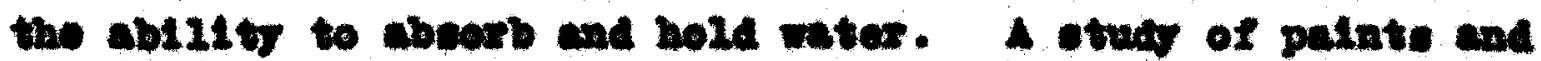

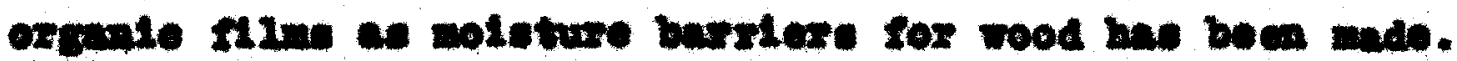
no ghe a somplote history of protective costinge for wood

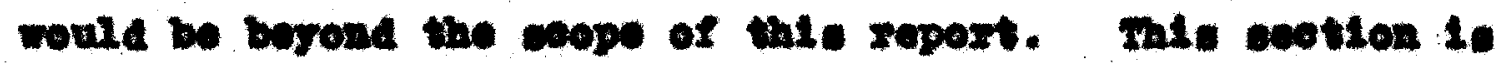

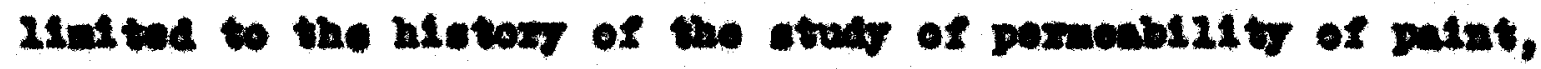
verald, and orthotie exgante time.

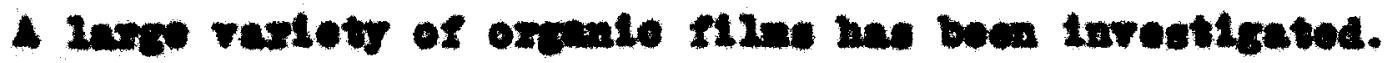

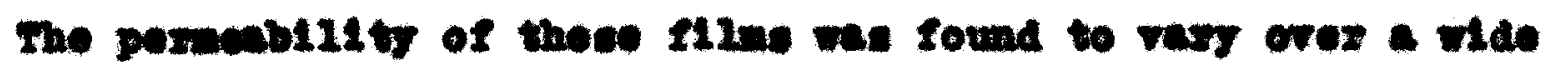

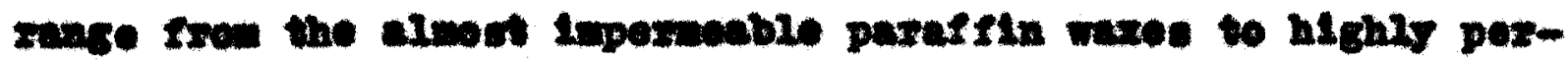

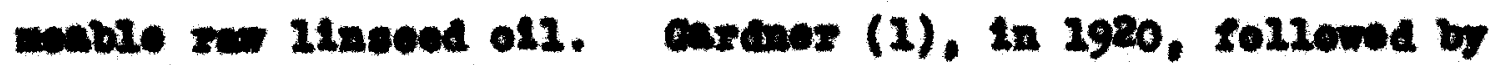
Deming (2), in 1926, the rorent Prodnote Inboxetery (3), in 1925. and Pand (4). In 1940, ctated that the nox Impxognatien of

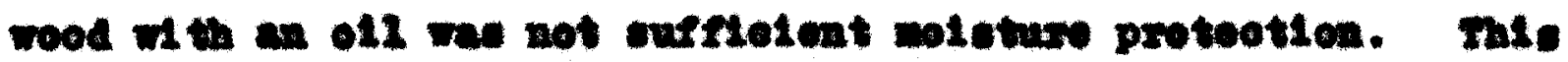

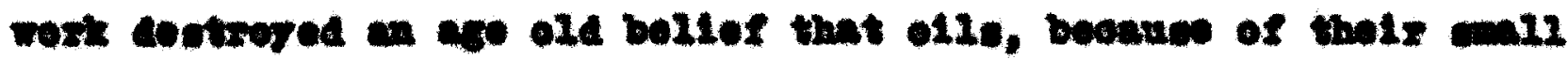

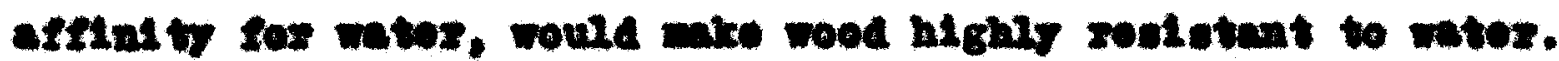

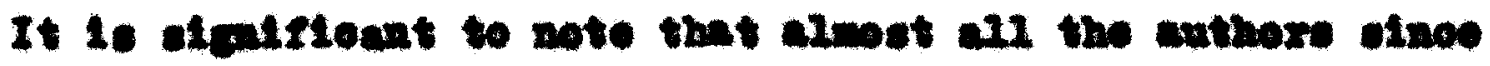

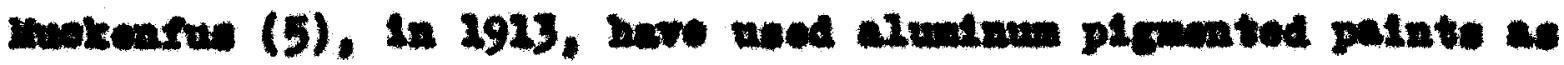

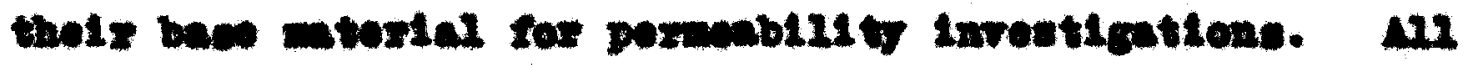
thoes atthore $(2,2,3,6,7,6,9)$ nech repor reotatanes tente

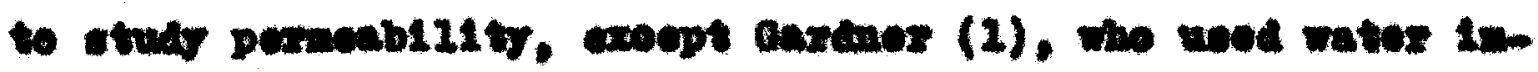

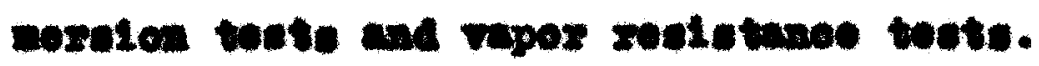


Carderer (1), studylag enamele, raral ohes, shollees, olle and dopes, reported the redustion in wolature plokmp of wood (oallod offectivenoes henoeforth) by using three ooats of onemol to be 95 per eont, but a mxture of 012 and graphite had vory poer effectireneas. Histed below is the per oent offeetivenees of flime teated by varlove anthore:

Compost thion

No. of

Pex oent

conte effeotivenese

Carmer (3), in 1920

An ennel of opar ramieh

Ampult palnt

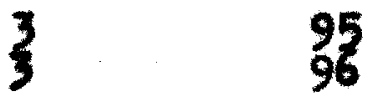

Forest Producte Laboratory (2).

In 1925

Qxpphito

opar rexnl on

hineed oll and wax

Alveinue and oper varnioh

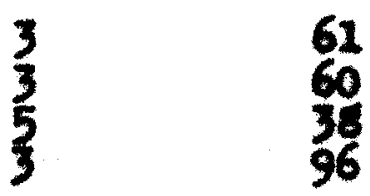

Dunlep (1), in 1926

Aluminum in plech

Asphalt onamele

Alwine is opas rarnith

Aluminua in opes varalob

Foront Prodnote Leboratery (28)

18 1935

rumlture wax

Rubblas ranido

anclise

Aluinew In acphalt

Alund new in acphal

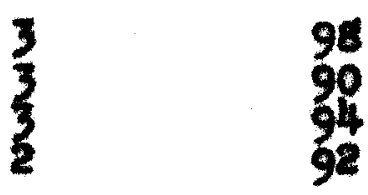

In 1933, Brewn (8) and Wrus and Van Voret (7) dewenstrated the deorease in pexmeabizity of palnt filna with a deoxease in plegent partiole alse. The inorease in effeotivenes of a paint III with Increaling plgment ooneentration has been dewonetrated 
by Cardnop (2) and trey and van poxts (7). The addition of

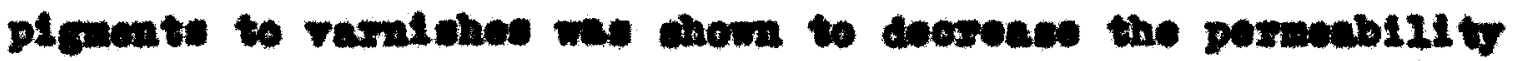
of 111we by way anthose $(1,5,20,21)$. Howover, in 2936,

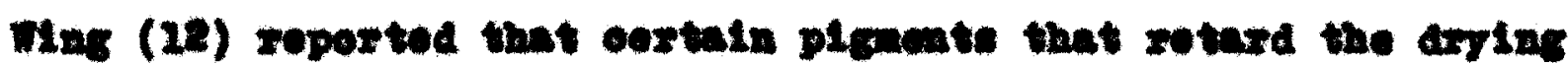

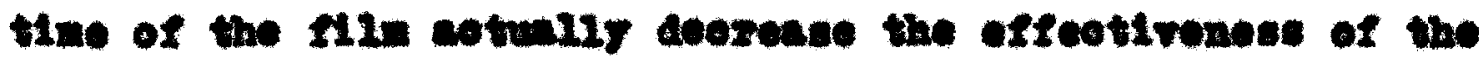
ramish. Curduos (1), oupported by other suthore (25, b).

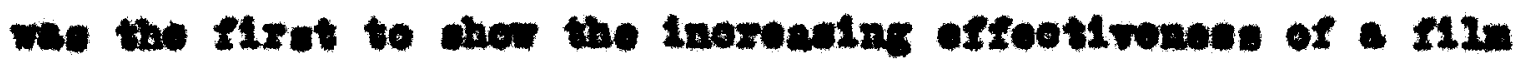
Tth the wabes of coste appliod. In 2926, Dunlap (2), workIne Fith varioue cestlnge, found that eppliostion of a woond

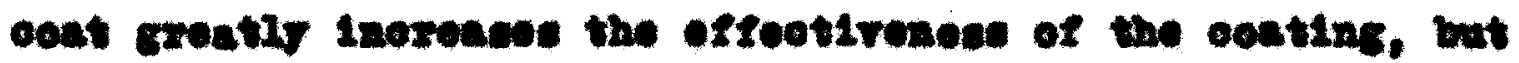

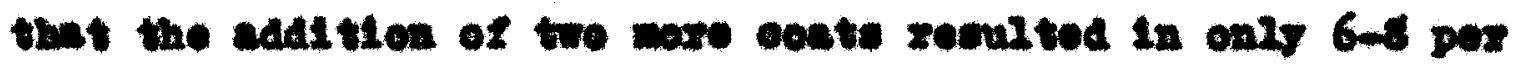
eent Inoxwees.

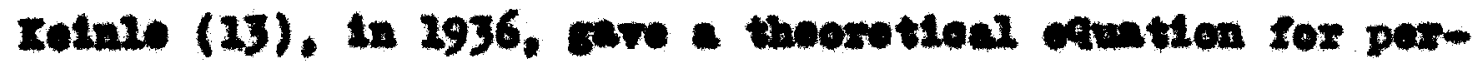

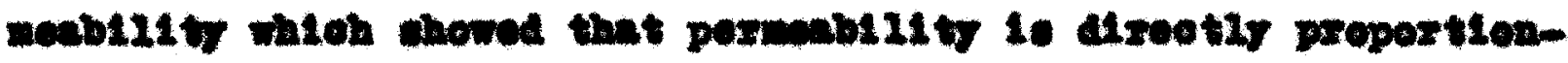

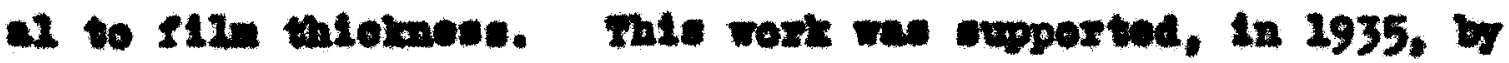

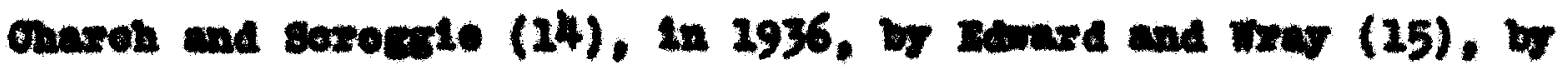

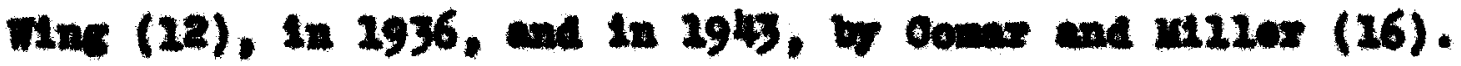
Fayn and Garmer (27), In 1936, tound rolnke's equation to be

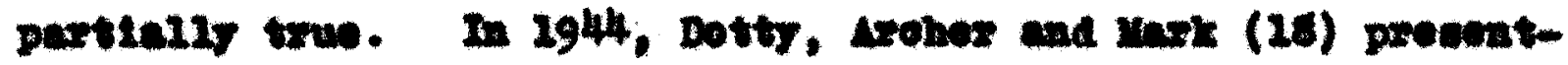

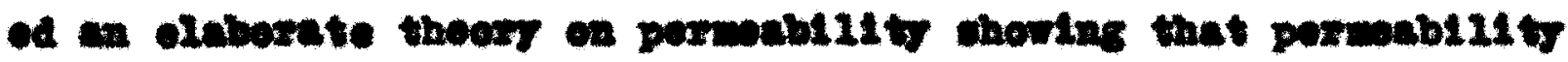
wo boportional te filn thiolnoes coponding upen the nteziel.

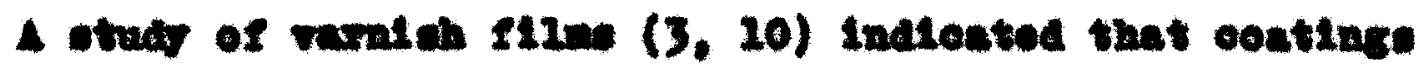

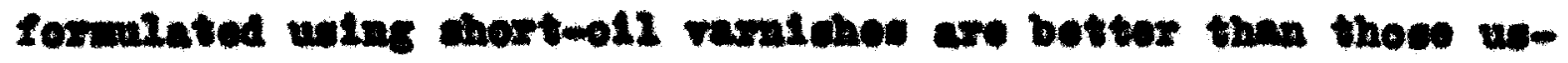
Ins leag oll varat bos. The effeet, bowever, is not grest. 
Fayne (19) reoomended uatie bodted olle Instead of blown olls. Edwaxds and wroy (15) and Payne (4) reoowanded bakles

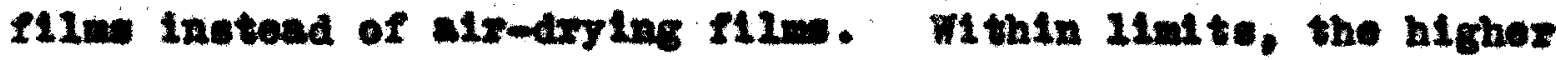
the temporature of baklag the lese permable the film. Serv-

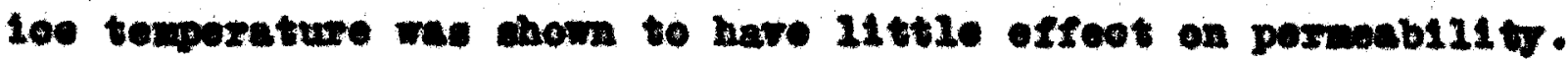
Wray and Van Voret (7) found that astng a filn inoreases its effootivences.

Cardmos (1) demonetrated thet may film are as offeotive egainet rapor at they are agalnot watex. Dinlop (2), in 2926 ,

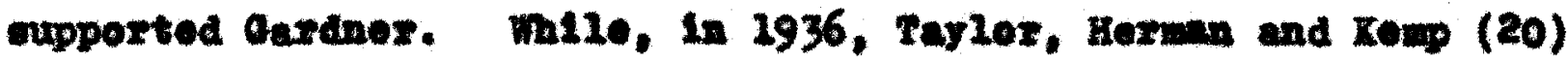
and, In 1937. IIIne (11) found this rale Invalid in oertaln oases. The simplest explanation postrilated to explain the woohanten of alffucton through a fil was the oldentoal theory of water diffuet on through a son-pormeable mombrane. It was

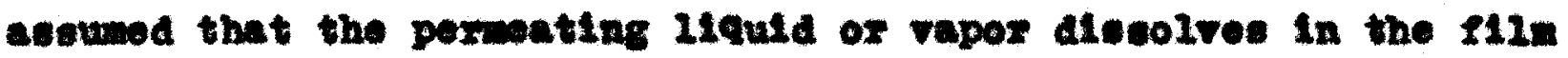
and oveporates from the solution formed. Howorer, Homy' It It Indloated that pexmoation based on this theory would be InveresIy proportional to the texpexture. Anee it had been ohom (15) that temperature had 21tt2e effect on permeab111ty, Payme and Gardner auggested that fectors other then slaple diffunton were

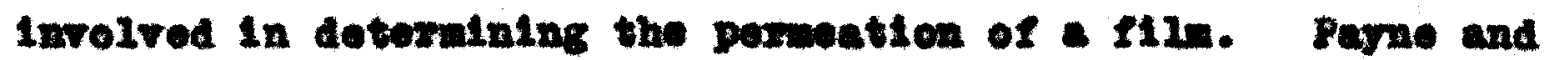

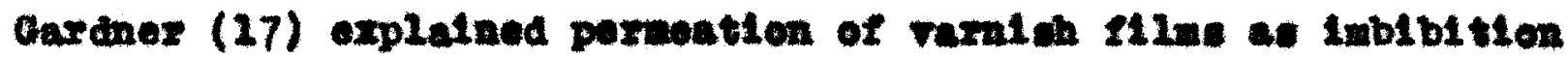
by the flin whioh forees the olosely paoked flbrils apart forming opplilaries. Then diffuoton takes pleoe normally. Later. in 1944, Payno (19) elaborated on hle explenation by lieting five propertice of flime Involved in pormention of orcente flime 
(1) peroot by (2) adeorption and aborption; (3) imbibition; (4) relative polarty; and (5) volubility. Dy far the moot Impertans feotore inlinonolng the pexwestion of an epperontiy good 112. vere polarity and Imblbitlom. The oharwotertatlo of pelaxtty we show by Cardeer (21) to be reoponolble for

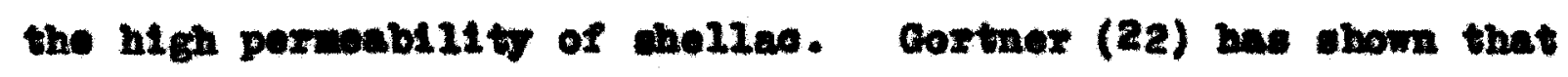

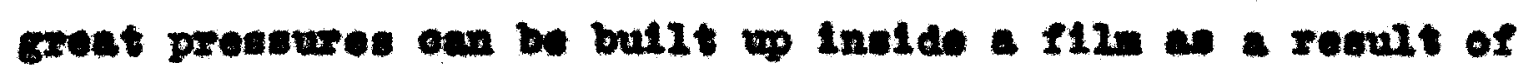
Imbibltion preasures. In 1944, Dotty, Arohor, and Mark (18) presented a theory explalning Paye and Cardner's (17) work.

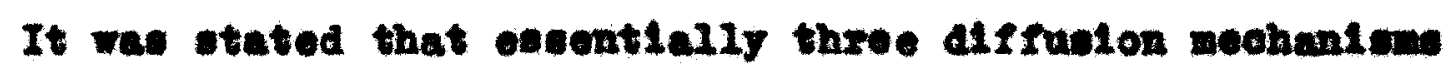
take plaee ot onee: (1) woleovies enter the watrix of the flin

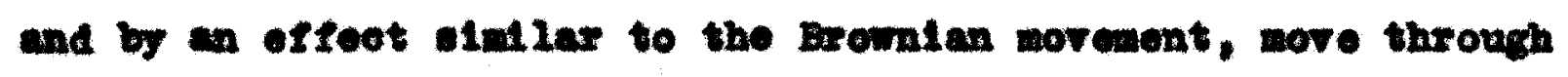
the 111m; (2) woleoules enter the onpLileries in the film and by robounding from the wils, wove through the $\mathrm{flim}$ and (3) a comblnation of the riret two woobantem.

Hany wethod of teoting 141 we hore been reported with varyIng results. Carcher (I) teeted palns flime by coating wood seaples and, after welghing, Imarelng the eamples in water. The galn in weight of the eaple noted after remoral from the water was the rate of pormoation of the films. KIIn (23) atated that the permention of a I1I wes the wame when 14 was exposed to water so won 14 wa exposed to vapor. Wray and Van Voret (7) found the pownobility of three ooste of a leoquex 111 s to be higher in oontruet o1th water than with alf catureted of th water but that the roveree wa true for a 
alnglemeonted laoquer film. Tarlor, Herman, and Korp (20) found the permeabilt ty of som materials to be appreolably hichor in weter thm in water outurated alx. In a later

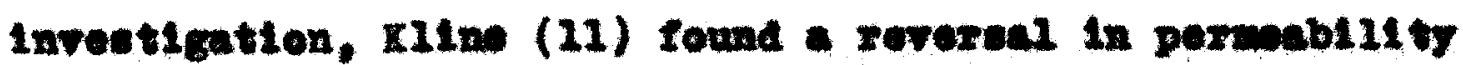
of elkyt and phonolle rerules flim when the partiel preseuxe gradients of water were rexled sovose the film.

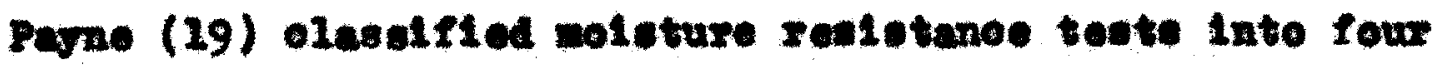
ontecorte: :

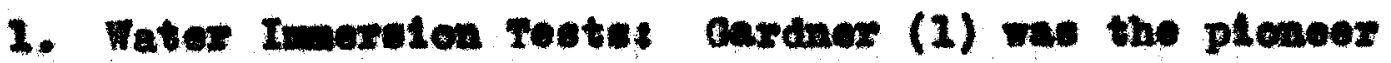
In thle type of toet. His proeodure has bea previouely

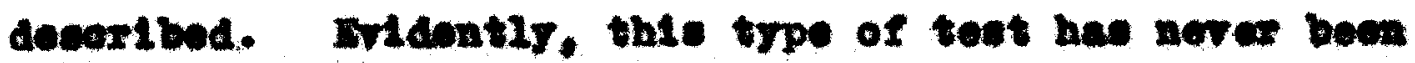
nodrise.

2. Doper Poxmoability Teatef The largest number of Inreotlgaters have ueed thle nothod for walnation of 111 w. Iuskentue (25) in 1923 ploneered tht work by oouting wood eamples with 117ms and sealing the wood to a water contelner. Brown (8), tosting oostings on wood samples, stresed

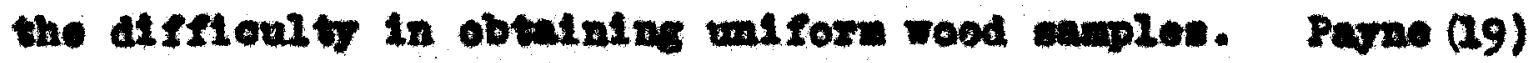
ctates, however. that the reolotance of rood in tooting rilm 1. mogligible. Iosentieliy, all thee types of apparatue were almlix, dopending upen the nesoumenont of the rate of worement of water vapor eauged by a partial preseure gradleat to weseure the perwability of the flin. The Fow Tork Palat and vinalon olub (20) dosertbod proeodure in 1937 that is reprecentative of the group. Peyme (19) disoused coveral of the typtoal typos. In 2941, Durr and stam (23) 
andysed the problene involved in soourately measuring the wates rapor permeability of a 111n and deeoribed an apparatus whioh they felt gave preale values. This conclatod essentlally of roworing the stagnant alf f1Im

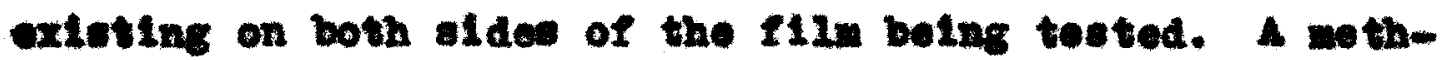
af of bosouring the gas perweation of materiale of 10 w permoablilty was desortbed by ghuman (24).

3. Ineotrioal Realatant reatet obtalning film permeabilt1es by alctrteal breakdown wes a mothod desortbed as monewring the ohange In conduotance before and after wetor repor exturetion.

4. Oheal oel Laviyole Tentet Chenleal mothode of per-

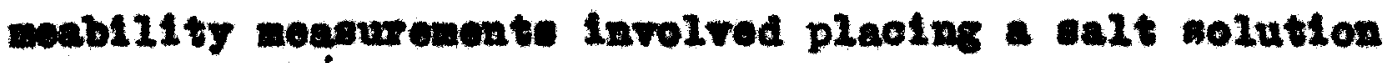
on one alde of a flin and finding the ohange in salt oonoentration during a time interval. 
TEDOEIIOL4 
. This seotion of the roport is cubdivided into fire seot-

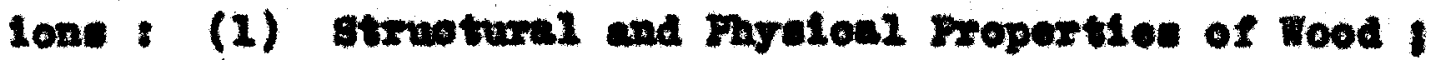
(2) Poxweation of Milm; (3) Propertice of Alutinum Porder

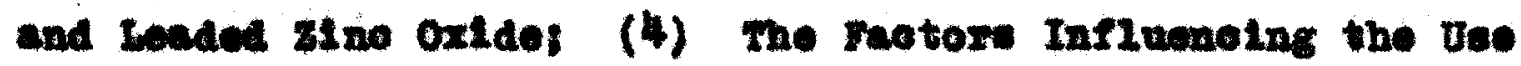
of Vapos Permeability Apparatuef and, (5) Fooretioal Oonclustone.

The discusetion of these toptes In swooeding sootions is cumerised below:

1. SAnee the Investigation Involred the coaling of wood, the firat ceotion is dovoted to discunding, In general, the atruotwe of wood and the phyatend properties inherent in Douglas flx. Thus, sinoe the obnreoterietioe of wood are known

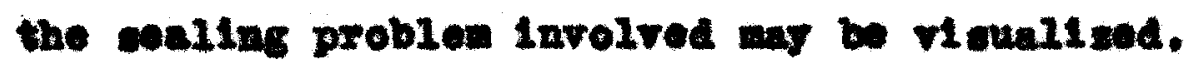

2. One wothod of roaling wood It to oast a fil on Ita murface. Thle procedure was adopted. So that the reabone for the awooese and fallure of rartow ooatlinge way be undozotood, the nature and faotore influenolng flin permobility are dibovened In this wot10n.

3. Uany organto Iline alone ounnot effeotively ead rood

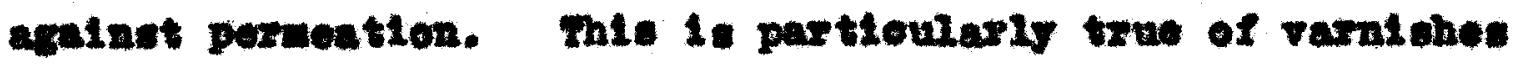
and laoquora, but the eddition of a picont to these coatlage:

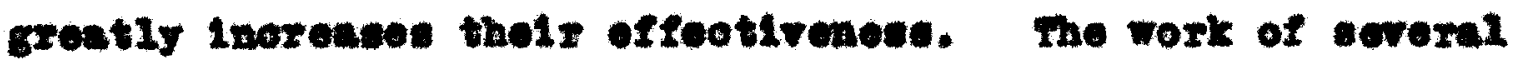
InventIgatore, uning eluninum plgnented continge, Indiostes, that this piguent is quite aperior to othere. The reasons for thl phenomenon are presented in this neotion. Howerer, an aluninum eolor wes not alway sultable se sealer, and the 


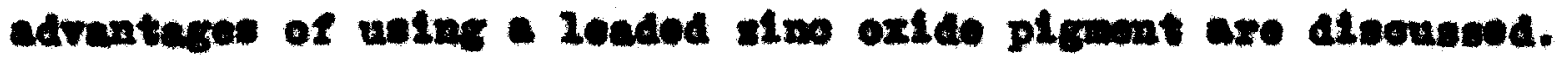

4. In cvaluating veper barriere un eppexatwo we nocdod

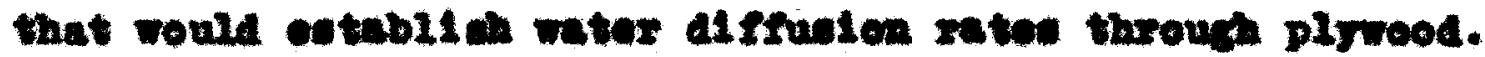
soreral trpes are know and those are atwoubed.

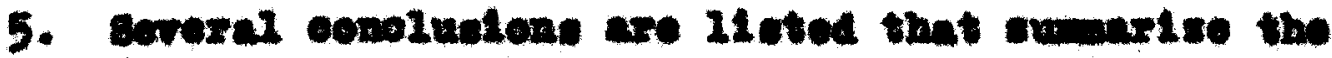
Infermatien preponted in the theoretion and bietoriod seotlone of this roport.

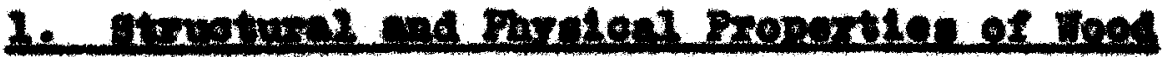

Ho attempt is mat hexe to domerlbe oopletely the oomplex utrusture of reod ox the varlations in gpoles. 4 oom-

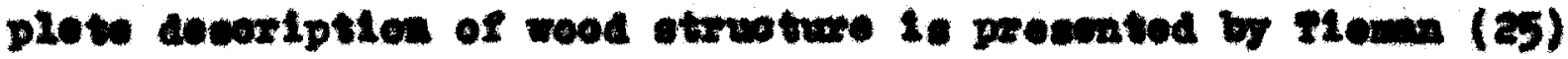

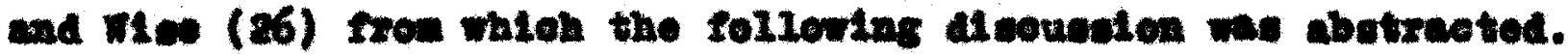

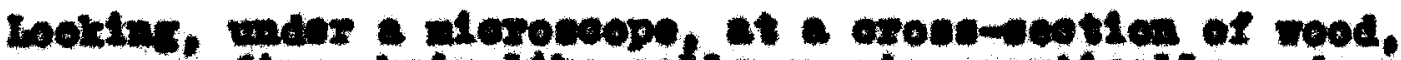

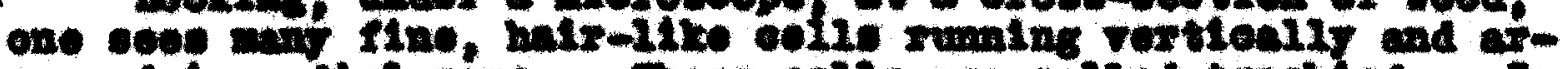

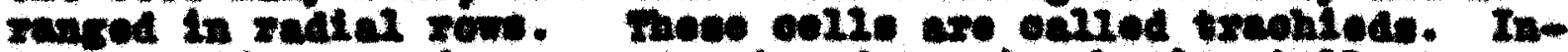

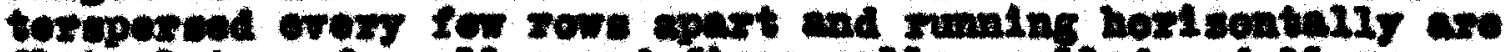

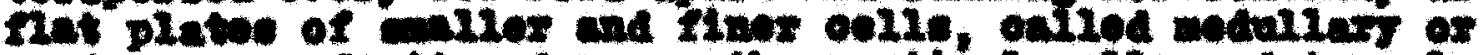

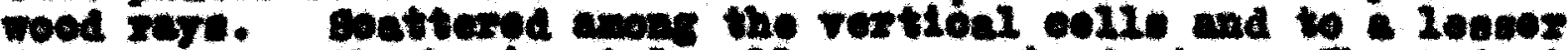

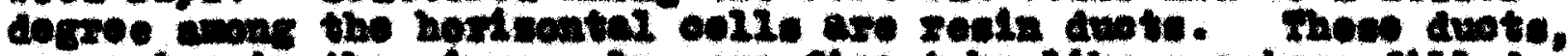

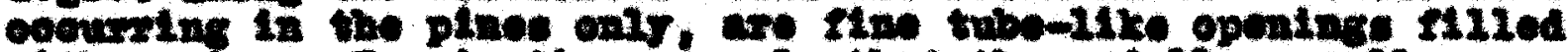

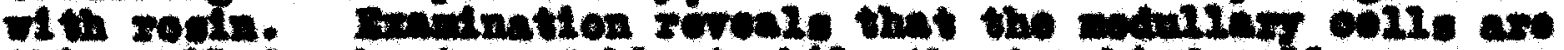
thin-wiled, chort, and blumt whle the truebled oolle are Feo-

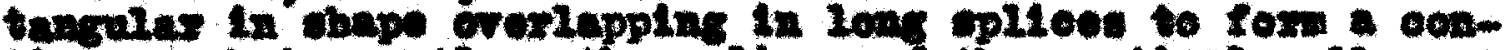

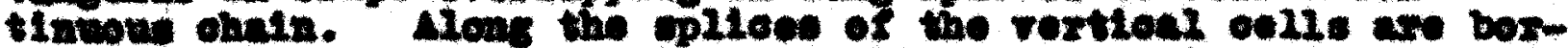

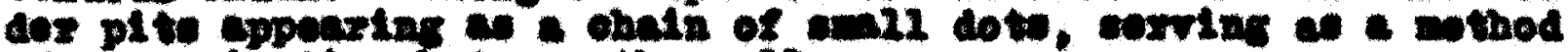
of convalostion betwen the oolle.

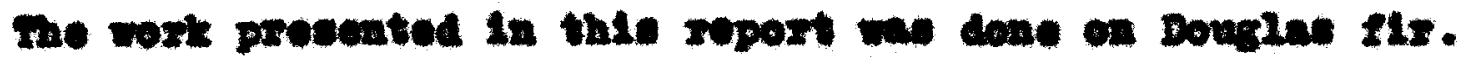

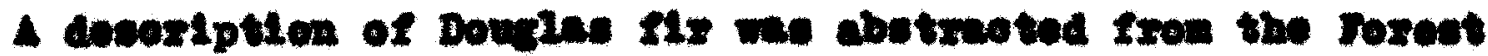
Produste iboxatoxy Dindbook (27, 25). 
The propertloe of Douglas flr are affeoted eowownt by the loostion of the otend (geographloul looation). Moot etruotwral Bougles fir comes from the veat oonet. The outer larers and lower sectlons of the tree furnt ch the best outs while the upper and Imez outs are reletively coft and lees demes. me rood is Btrong, moderately hard, henry, durablo, he a tendonoy to oheok and oplit, and doos not hold palnt well.

The palnt holding proportios of the roed way be Ingroved by the use of aluminu plgmented varnileh primere of white leed

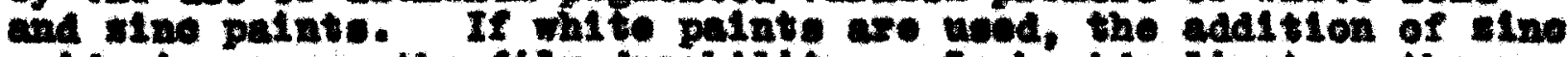
oxide Inoresese the filn durability. In humid ollwetes, the wee of alno axides up to 50 per oont of the total pigrent content

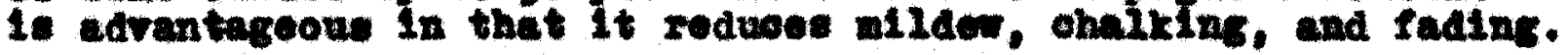

Fater 1s held by wood in four waye $(26,29)$.

1. Water of congtitution

2. Gure reo-bound vatex

3. Caplilary mondeneed vater

Water beld by the firet three nethode is alnont alwaye provent in wood, but it is with the fourth mothod that this xepoxt Is oonecznod. Froe water is pronont in wood only as long

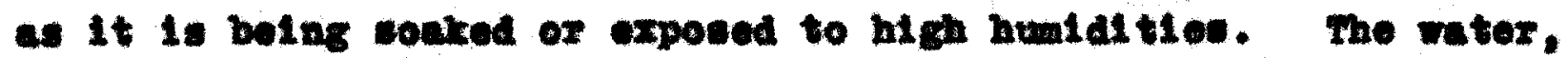
In this eave, is avoribed in the oaplilaxies formed by the traphede. The Imbibition preasure of the water fores the flbxils apart waing roon for wore water. This procese continues unt11 the strength of the wood is ouffiolent to oreroone the Imbibition presenres.

sobors and stan (30) have presented the glemold ourve for

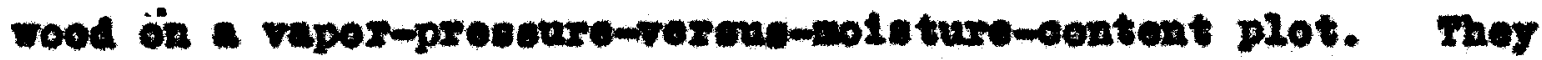
obeerved that the coerption ourves wexe hichor then the abeorp-

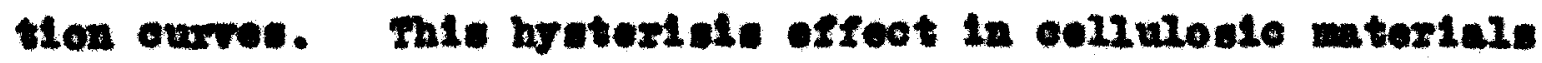
wae firet obeerrod by taseon and Rloherds (31) in 1906. Uxquhart (32) and Drquhart and W1111am (33) prosent the wost plaus- 
1ble explanstion of this phemowenon : As watex is abeorbed by wood, the free hydrozyl groupe become sat1sfled. Upon desorption ahrinkage oocurs brinting the new freed bydroxyl

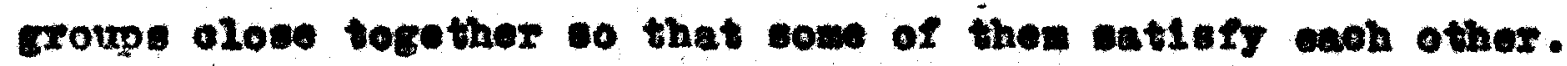
Henoe, upen abeorption, again, there are lees hydroxyl sroups to be satiafied and lose water is abeorbed. 2. Perasation of Filne

41 organte fllw have a gel strueture - this belng a collodiel syotom. The gel struoture 10 composed of unlte, oelled fivilis, varying in atro and bound togethes in a hap-

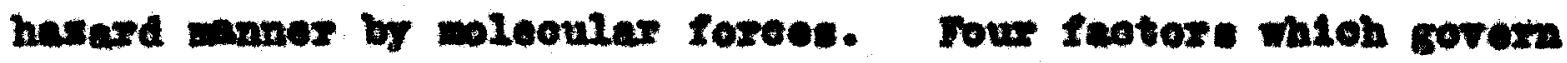
the rate of gel formation are

c. Holecular ales dietribution in the original liquid

b. Rate of eveperation of the velatile oonati truat

c. Prooese of Ilquid oonveraion to the gel ptage

d. Irpe and coneontration of any colld dieperead phase

The oharecteriotlos of organte surface ooatinge whioh obtermine thls degree of water permoabli1ty are

a. Film peroesty

b. Ldeorptien and ebeorptlon

- Imbibition preseure

a. Rolative polarity

- Bolubistts

Parne (19) disouened theoe properties as followet

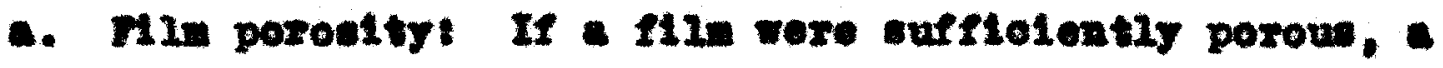
11quid wourd pase through 1 at a conotent rate. Organie $112 \mathrm{~m}$, 
however, are not Initlally porous enough to oxhlbit a constant rete of pexwostlon, but after euffiolent owelling coeurs, an

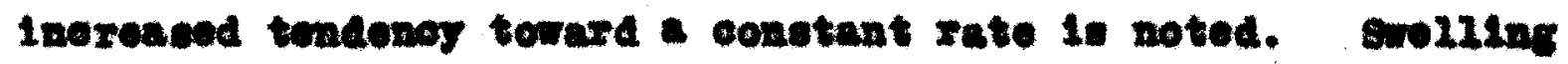
tends to coparate the IIbrize of the 111m, theroby Inoreacting

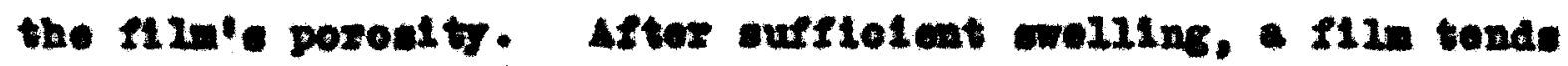

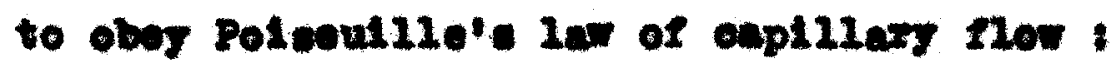

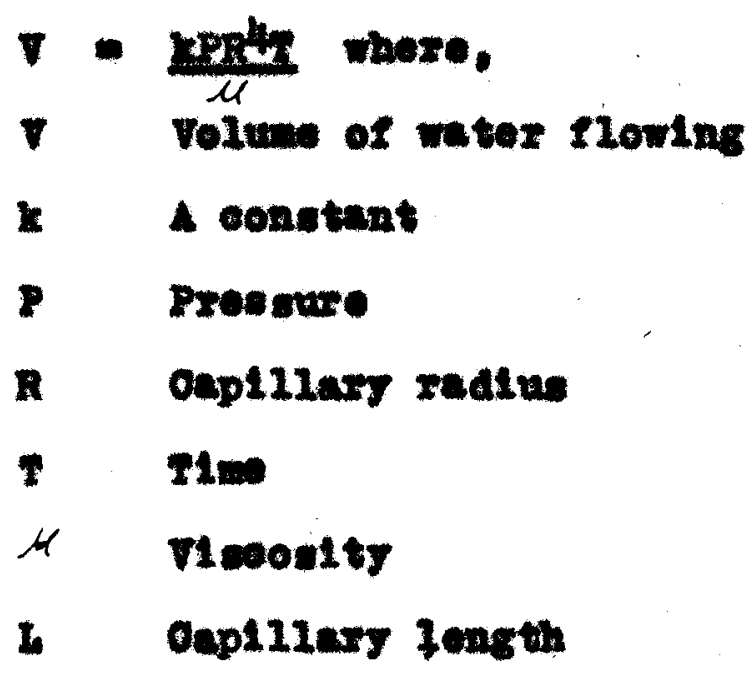

From this aqution it was conoluded that the sdatton of a

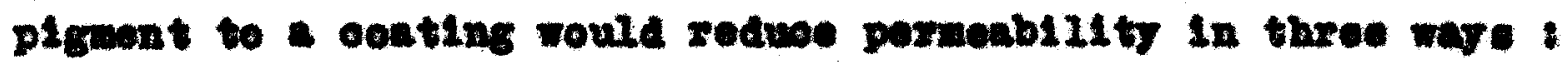

- Increase visoond ty

b. Redwo the number of oxplilaries

- Redwe the eaplizary radiu

b. Mdeorption and Aberptiont Adeorption is the phenonenen that peoure, whon one mbetanoe makes oontwot ith the surfeos of anothor subetanos. There axe three olvedifloations of wator edeorption

- Leohantoul - The adeoxption remulting from woleoular oondonostion on a film orrteos

b. Ohenion - The cdeorption reoul ting tron water wleoule otriking a owfece and fornins a new compound

o. Heotrion - Tho adeorption roulting from water wolevies beld at the filn ariace by polar foroen 
All three weohantew mer coove eteultancously. Howner, the offoot is eadil compared to the awount of water paselas through a 112. by aboorption.

Abeorption is the paseage of water through the inter-fibril spaces. In 1944, Dotty, Moker and Hark (18) gare an exeellent decoription of this weohanisw. The how of wolecules through an orgento pelynor wes ploullised by three wochanlems

c. Inow through oap111arios - By virtue of Ite kintle energ, a moleoule onters a oaplilary of the 112. Being retieoted from wall to well in a

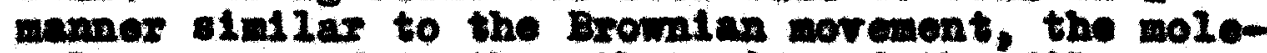
oule energes tron the othor 116 of the filn.

b. Aotivated diffusion through the polymex matrix Bowe of the noleoules oolilidag Fith a nomogenous, amorphou matrix of the 111. WII rebound and othere will ponitrate the filu a low etomic layere. By virtue of 1ts onercy, the moleouie noves about oxeating a enall hole Into whioh it moves. The old vaont hole oloses. B this wothod the moleoule Ilanily pesses through the P1Im.

- A combination of $a$. and b. - A thira proeess coowre when watex ohonicaily oombines with a flim's free hydroxy groups. Iter thermal Ilvotuntlone due to moleoular vibretiona cauce the water molooule to fxee Iteolf and to continue diffuelng through the 11in.

From this disouselon it wa oonoluded that a filw could be Improved by

a. Radualng the free hrdroxyl group

b. Roduolng the zelative polarity of the fila

o. Adding plement to the film to reduce the number of oepiliartes

d. Inoreasing the toughnese and hardness of the film

- Imbibition Presaureat lo oomplotely eatlefactory ex- 
plenation hes been offered to acoount for the phenowenon of Imbibition, but it has been reoognlsed that it is ralated to relative polarity, abeorption, and gel otruoture. When a gel, wow as gelatine, 10 placed in water, a large amount of owelling ooours. The expantion of the gel 18 due to 1 mbibltlon preasures developed by the water. Cortnex (22) has thown that thi presaure may become very large - large enough to rupture sted enolosure. O1asatone (34) statea that certaln alte will inhibit Imbibition whlle others inorease the effeet. The preasure doveloped will eapend upen ph bolng a minlmum at the Iseolootrie polnt.

$A$ deflnite degree of absorption and relatiro polart ty have been obeerred as neoesary in a $112 \mathrm{~m}$ before imbibition prosauroe can be developed. This is further lndicated by the elmilart ty of abeorption and Imbibition ourves plotted versue time (35, 36. 20, 17) whloh are parabollo from the origin.

d. Rolative Polarity: Relative polartty lo defined as the - leoticion attraction exibited by two moleovles for each othor. Polarity in a woleoule is the reoult of unoymotrical dietributIon of posttive and nogative oberges es would be oaued by an acle group, a hydroxyl group, or exritloally soattered double bonde. Saturated hydroearbone are nos-poler while wany restne and drying ofls are rolatively polar.

The effeot of moleoular linkages in combating polarity hes been dewonetrated by two phthalates, glycol and glyoerol. Both resins are quiet polar. Giyool phthalates are etraight ohalnod 
realns held together by cohedive forees of the eceondingy valasoo type. These glyool realne axe quite permeable alsoe the imbibltion preasures developed overoone the strength of the stralght ohain 12nkeges. Howorer, the glyoerol realns are three dinonetonal polywers. The strength of the orose IImkages are ouffiolent to reduoe the of fects of polarity so that this realn is widy ued in wolsture barrier formulations woh as apar rarnich.

midently, then, as may be seen from the above diseusaton and the conflicting reporti preecnted in the Historioul seotion, only a guese oan be wade as to the aotud sechani on of permeat10n. The author ha formulated a theory both short and simplo that w111 eseontlally explain perwablitty of most palnt 111 a. Aserme a theoretioal 112 with gel structure of olosely peoked fibells. Mllow the flin to be mbjooted to a partial presoure water grodient. At firot an infinttestme anount of whter $\mathbf{1 1 1}$ penetrate the f11m by adeorption and by kinetie energs

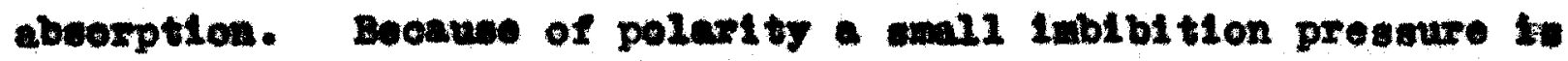

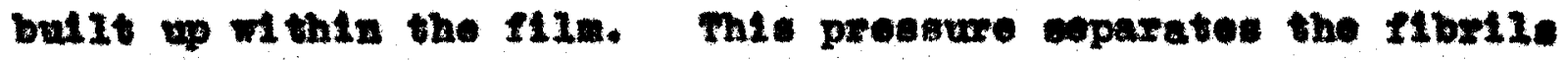
ellghtly so that more water oan be abeorbed and larger presenree

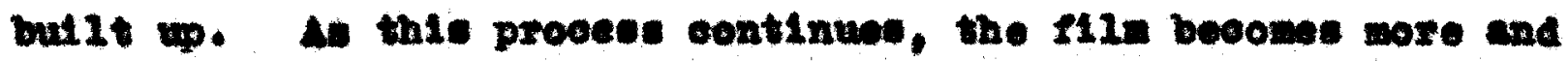
noxe porew int1I the FII etrength orexoones the Imbibltion preverure. At this polnt, oonatant zate pezweatlou oocure. If olgniflownt anounte of water are pasalng through the film st thie tino, It 1o almot all due to oupiliary how. This explanation 18 not weent to be Ifgorous but werely a ample means of rioual- 
18ing perwention.

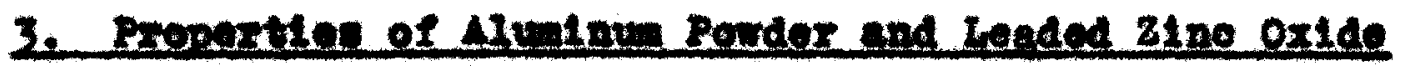

Albulnum powder bae the unlque property of tonding to

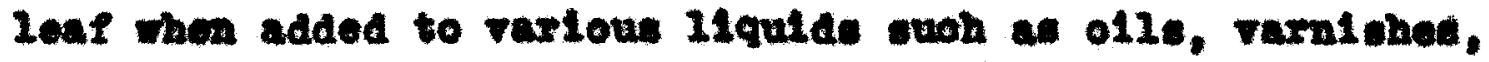
and cone solvonts (37). Thon alunimu palnte aro epplied to a curfece, sons of the plgment nakes float by means of conveotion ourrents, to the top of the IIIm. Although a continnow Ieaf is not formed on the nurfece, the top lager and suocoselve undor Injere are co arranged a to lorm a tortuou path for the pesange of water through the ooatling. As a recult, aluminum palnte are almost 1mperviow to water and water rapor.

71 eoow rohleles rotard the learting propertles of alvalnw. Phonolle and eiryd loag-oll varnithes of $10 \mathrm{w}$ seld velus are exeollent rohloles for alum man. Ooal tax thinnere thould be used avolding lend driers.

Alwainu oolor was not considered sultable for odge cealere and the we of this pignont wa lintted to vapor berriere. Loadod sine oxlde, beling reoomendod as an exoellont plgment for painte belng applied to Douglae fix, wa coleoted as the sooond ohotee for odge soaler formulation. Ioaded sine oxtde I. couposed of baste lead sulfate and sino oxide (38). The plguent oosponente and appear cofwed or as Indirldual oonotituente.

4. The reatore Innuenolns the vee of Vepex Permability Apperatur 
unas trpes of apparatus have boen deseribed in the 11texature for wasuring f11. permenbility. The good ones are ossont1ally the sam. Durs and stum (23), 1n 1941, docoribed an apperatue both simple and apparentiy acourate. The callent foatures of a good permoablilty apparatus were desoribod in the report and are listed below

1. The auple obould be sealed in a relghing bottle

2. Lon repos prosenres should be mintalned in the melghInt bottios while the high hunidities should oxtat on the oxtertor olde.

3. The surfece of the salt solution in the bottles must be continewoly broken and the alr abore the eolution elroulated.

4. The botties abould bo plaoed in a constent bumidty roon equipped for alr olroulation and thermostatto control.

5. Iegleot of alz elroulation and breaking of the 11quid ourfece in the botties may reavit in permechlilty valuee 40 pez oont below normil.

\section{Therstient oongludion}

The coneluelone that hare been made, beed on the work of other experinentere, show that the effootivenese of variou organio fline agalnet water and watar rapor way be inoreeced by

a. adding a plgment to the III forming aterial up to polnt where the further addition of pigment would ouve rapld doterioration of the fill.

b. deoreasing the plement partiole atse.

- wding nore than one cont, but the increaged effeotlvenoes 1s not nocosserily direotiy proportlonal to the number of ooate applied. 
d. Inoreasing the visoosity of the flim forming water1al before it is applied exoopt where "leafing" plgmente are need.

- agting the 111 in for a ohort tim before testing tor matm effeotivenoss.

t. baking the film inatead of atr exring.

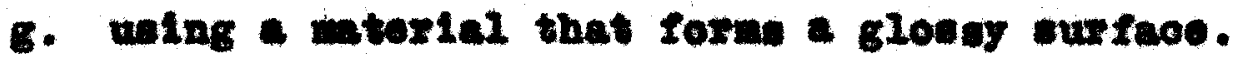

h. whing oresen linked and relatively non-polar vehteles.

1. avolding free byaroxy groups.

1. wing chort inotead of long oll vohlelea.

x. ualng aludnum and alno oxtdo plgenti in coating to be used in oonneotion wth Bougles IIx.

1. uoling onsmera.

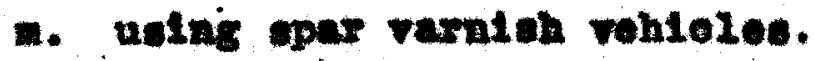

A ohange in effootivenese obould not be expeoted with a ohange in the cervioe temperature. Squal reelotanoe to water and water raper way be expeoted but need not oocur. 


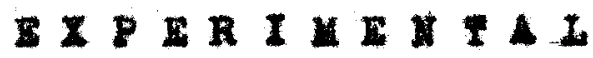


Ooatinge were dentrod to eerve two functiones (1) a - water barriert and, (2) as a rapor barriez. Two trpes of tests were seleoted whioh would show readily the per oent offectivenees of the varlous water barriers and water vepor berrlexe. One of these tosti was a simpio water immerelon teat. The other wea a teat denlgned to show the rate of wator rapor alf

The work is preanted in four ecetions:

4. Wter Imoretion Pest of Water Barriers: In this test varloue trpes of amplos new tented to confirm provloubly roperted sevults, to olarify cortaln oonflloting reported reavite, and to piek out the boet miterial sultable for further invertigation.

B. Vepor Resl atance Tost of Inemel Water Barriere! The better eamples found in the first teat wexe oramined to see whother they had equal realetanoe to water vaper.

0. Water Immeraton Teat of Water Barriers: Attempting to

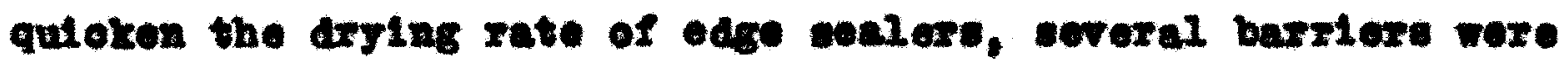
formulated ustag the prinolples establiwhed by the flret test.

D. Ivaluation of Natex Vapor Barrioret The diffusion rate of water through several palnt coatlnge and alwainum foll was foind in order to doterulne the effeotiveness of the barriers. 


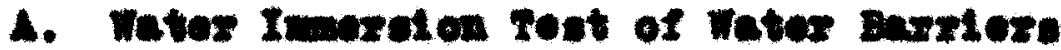

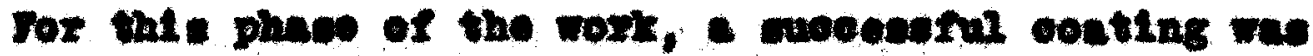

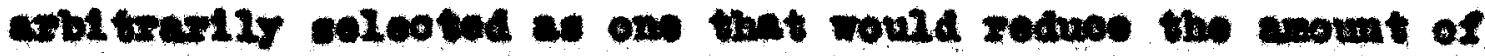

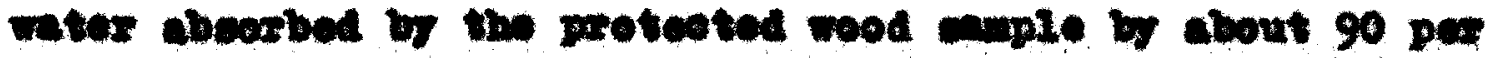

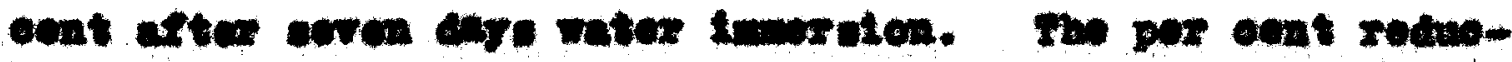

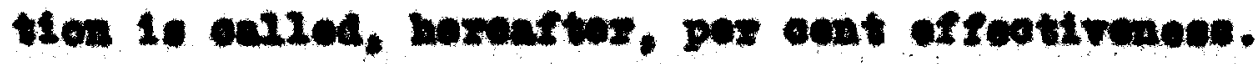

In riow of the thoery provonted and indentring Iintetlons of oolex, the wen of a whto curnel we ohosen as the pritaxy

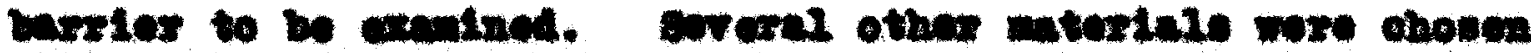

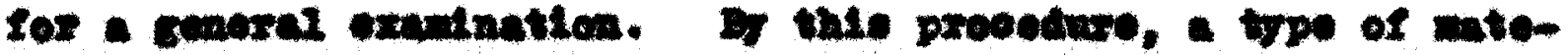

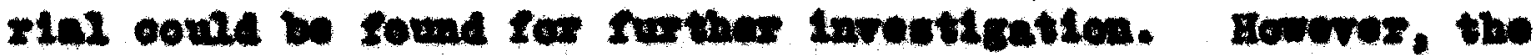

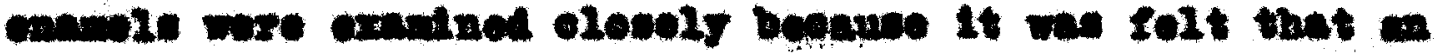

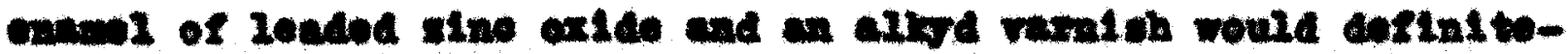

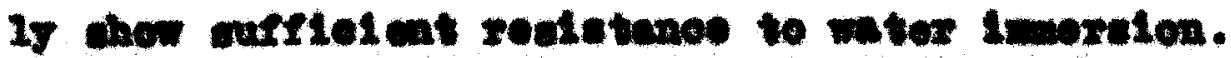

\section{Progentax}

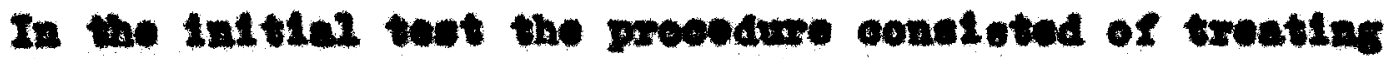

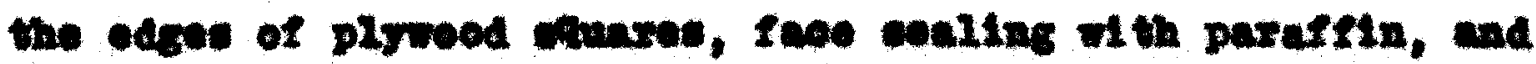
coutteg the ouplen in wotes.

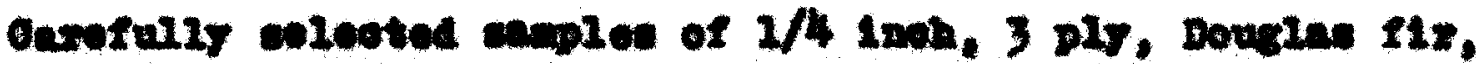

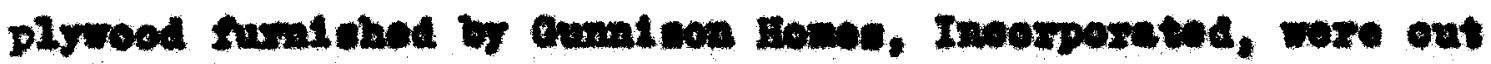

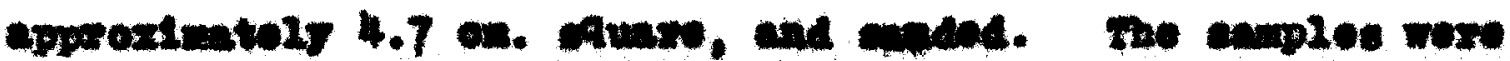

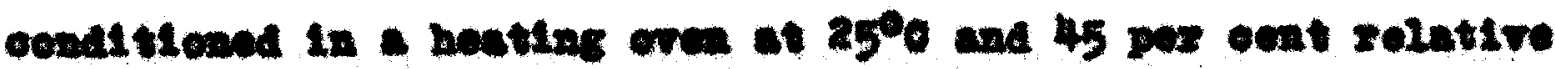

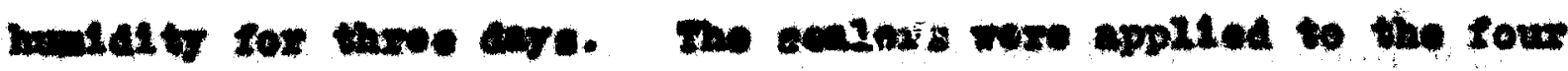

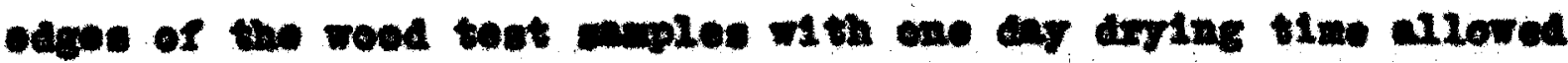

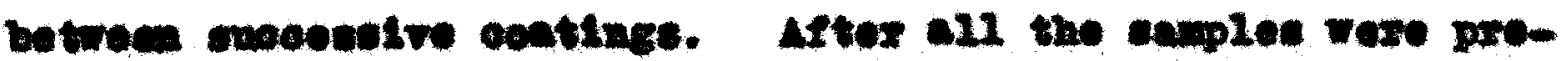

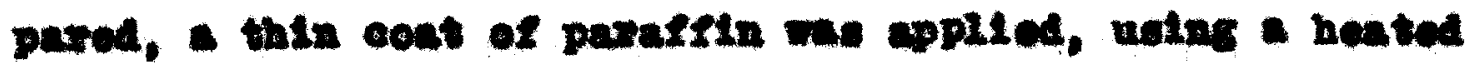


glawe rod, to the two feoes of the wood squnxed.

Five test eamples were propered for each sample molsture

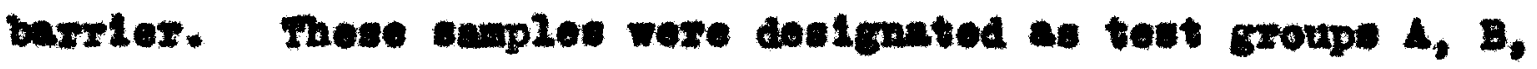
0 , D, and E, ceoh group reprosonting a Aftorent conking portod.

Test Group

$\mathbf{B}$
$\mathbf{0}$
$\mathbf{0}$ soaking Pertod

Three hours

Twelve hour:

One atey

Three dnre

Evren daro

After relghing the samples on an andytioal balanoe, thoy

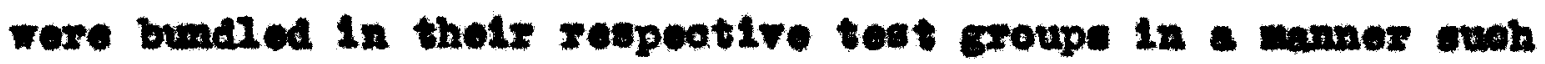

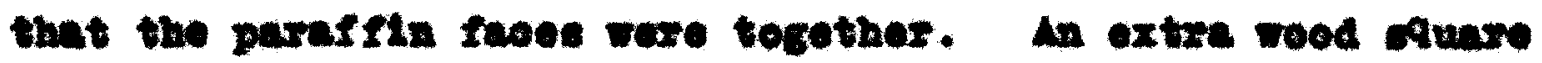
wan added to both cnde of the bundles. The five groupe were rolghtod and Inneraed in water at a dopth that barely oovered the eamples thus, ary precoure effeots were eliminated. Aftex explration of the raxlow secktag pertods, the eaplos were romored, mped dry, and reweiched. Ixantnation of the selples upon roworal fron the watex ohowed that the teomlque of parafining and bunding bad prevented any water frem rewoh-

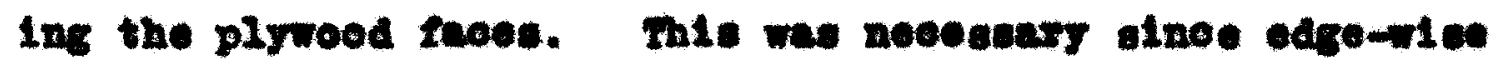
watez penetration was the cole interest of the work at this polnt. After rowelghing. the waplos were plaoed in a hesting orea and arled at $25^{\circ} \mathrm{O}$ and 45 per oont relative humidis.

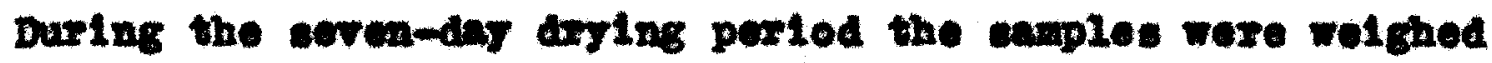
antiy. 


\section{Mteriele tented}

The compoettion of the enterials tested eppoar in Table I. Eumples one to ten rexe propared to chom that the oxese I1nkege of a clyoery phthalate roaln was otrong onough to orereone Imbibition proasures and polerity offeotn, to shem the effoet of plgnont in Inereaclag the effectivenoes of the bar-

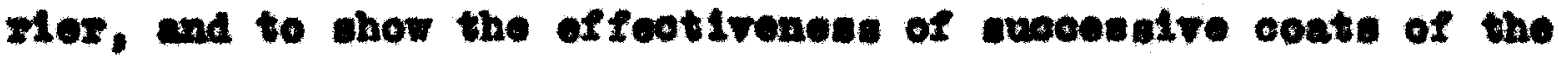
enamie. Heat resotive varnioh was applied to wood on the theory that it would inprocante the wood oelle, and upon polywerisation with heat, large wleovloe would be formed, eenilis off the "coors of watex entraned. Resee, the phonolle vernich eamples, elevon through thlateen, were applied to wood unt11 it would abworb no wore. Oblorofin 42 is a ohlorinated paraffin and was tested upon the request of the Gennieon Homes, Ino. Trafflo palnte are knom to have 11 ttle affintty for water and are westher realetant. A typloal traffle palat was formulated as sample ilfteen.

sample elxteen wae propared to seo 11 a thin varnish would penotrate wood and upon exying coal the ooll oponing. The formeldehyde that was added was rupposed to ald in water proofIng by resoting obenteally with the free hydroxyl groups of the wood oollulowe.

Bample ecrentern, of untrented wood, was wed for comparIeon with the woleture barriexe. 


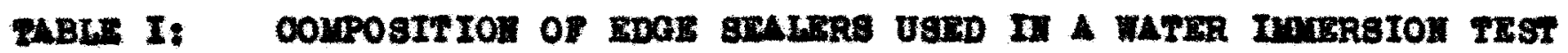

\begin{tabular}{|c|c|c|c|c|}
\hline Samp 10. & $\begin{array}{l}\text { Vontole Oontent } \\
85 \& \text { spar varnieh }\end{array}$ & $\begin{array}{l}\text { solld content } \\
15 \text { \& loeded stno oxlde }\end{array}$ & $\begin{array}{l}\text { oot oure } \\
\text { ar oryting }\end{array}$ & $\begin{array}{c}\text { No. of Oeste } \\
1\end{array}$ \\
\hline 2. & 85 \& opar varnioh & 15 \& leaded tine oxide & als arying & 2 \\
\hline 3. & $65 \&$ apar varnteh & 15 \& lomded sino outdo & atx arying & 3 \\
\hline 4. & $70 \&$ epax ramien & 30 \& leaded alno oxt do & atr dxying & 1 \\
\hline 5. & 70 \& upax rarni an & 30 \& leaded sino oxida & atr anying & 2 \\
\hline 6. & 70 \& aper varateh & 30 \& leaded sino extect & atr andas & 3 \\
\hline 7. & $60 \%$ opar vesinten & 40 \& 1eaded alzo oxtide & atr aring & 1 \\
\hline 6. & 60 \& eper vernieh & $40 \$$ leaded sine oxd 0 & alr dxytns & 2 \\
\hline 9. & 60 \& epar varnioh & 40 \& Ioaded sino oxtde & ats dyting & 3 \\
\hline 10. & 100 \& epex varnich & & ax dinting & 2 \\
\hline 11. & $\begin{array}{l}100 \text { \& phenolle heat } \\
\text { reactive varni in }\end{array}$ & & $\begin{array}{l}1 \text { howe at } \\
\text { 4000 and } \\
1 \text { hove at } \\
150^{\circ}\end{array}$ & 2 \\
\hline 12. & $\begin{array}{l}100 \text { of phomollo heat } \\
\text { reactive vernien }\end{array}$ & & $\begin{array}{l}1 \text { now at } \\
10000\end{array}$ & 2 \\
\hline 13. & $\begin{array}{l}100 \text { \& phenollo heat } \\
\text { reative varnien }\end{array}$ & & $\begin{array}{l}1 \text { hour at } \\
18000\end{array}$ & 2 \\
\hline 14. & $\begin{array}{l}50 \% \text { onlorofin } 42 \\
50 \% \text { aootone }\end{array}$ & & atr arying & 2 \\
\hline
\end{tabular}


TABLI I - continuad

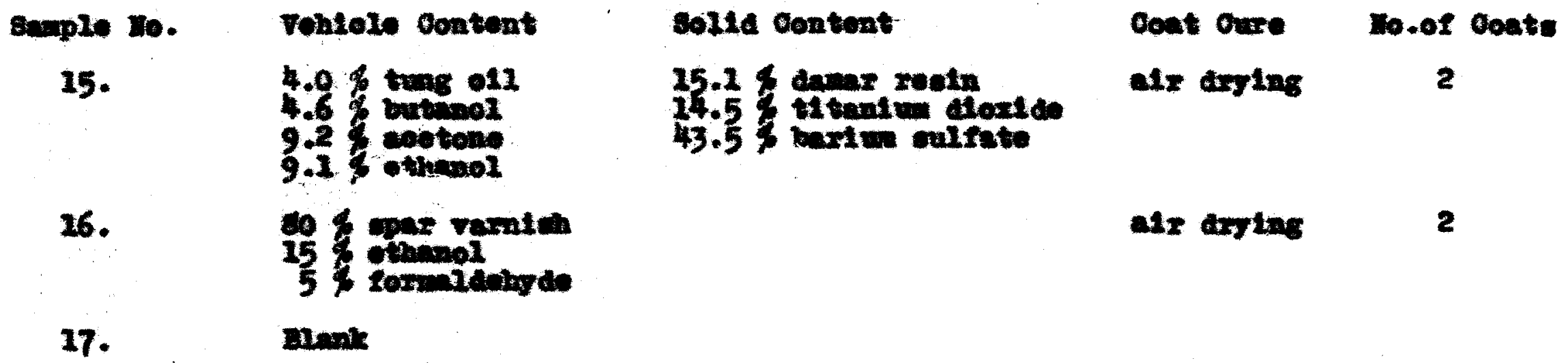

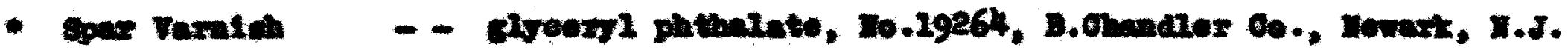

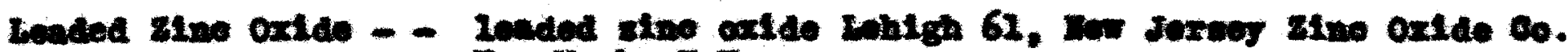
Ien Tox, I.T.

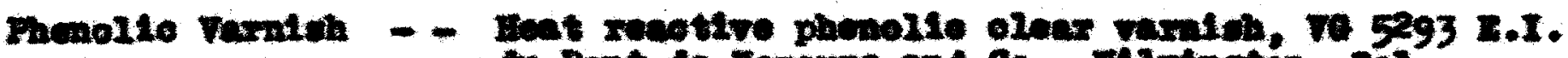

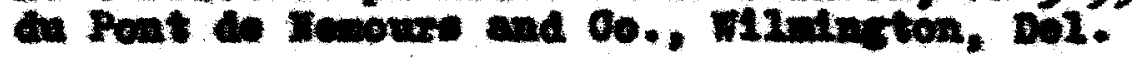

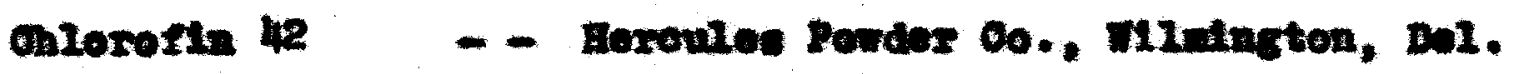




\section{Recults}

The computed reoulte are tabulated in rable II, rable III, and rable IV. Table II chowe the anount of water plokup by the eamples for each coaktng perled; Table III 11,te the amount of water plekup rotainod after seven eay couktng by the eamples of the evven-ies coaking growp: rable IV Ilata the per oent efrectivenese of the coating for each coaktng perlod. The experimental date and the compated reaulte of the drying of the other groupe eppears in Appondix B.

Water 10 abeorbed parellel to the craln muoh fagter than 1n other direotione. gtnoe three-ply plywood hes the eonter ply exose bonded, two oppoel te edges have two ply parallel to the direotion of water abeoption while the adjecent odges have only one. Consequently, whon the resulte woxe ouloulated to foot of ede length, the ralue was baed on the rate of water ponotration pes avesuge loot of odge length.

Figure 1,2 , and 3 how a plot of rables II and III. Tho 10wer half of the figures bolng Table II of the souking ourves, and the upper hale, bolng Table III or the drylng ourves.

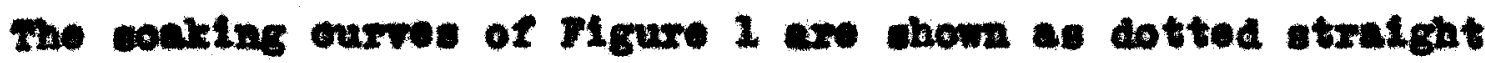
11new. The abecises of Mgure 1 represents lees then one

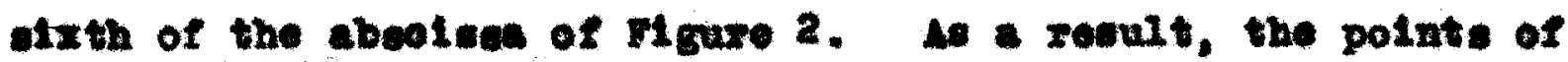

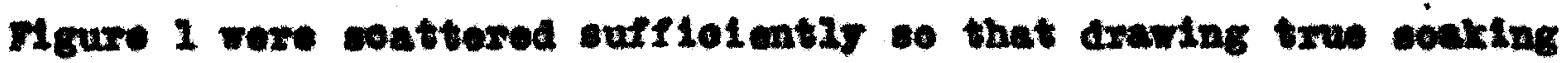
ourves was not juotifled. Mad thoce polnte been plotted on Iigure 2, eurves could have been dramn. 


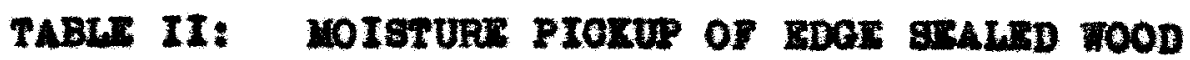

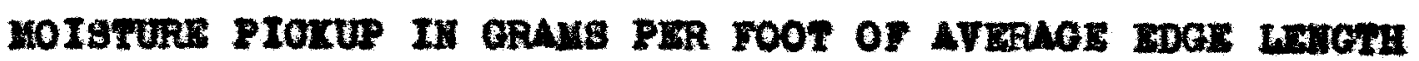

\begin{tabular}{|c|c|c|c|c|c|}
\hline Samplo Ho. & Group 1 & Group B & Grove 0 & Group D & Group \\
\hline $\begin{array}{l}1 \\
2 \\
3 \\
7 \\
5 \\
6 \\
7 \\
8 \\
9 \\
10 \\
11 \\
12 \\
13 \\
14 \\
15 \\
16 \\
17\end{array}$ & $\begin{array}{l}.186 \\
.039 \\
.050 \\
.248 \\
.036 \\
.032 \\
.636 \\
.029 \\
.018 \\
.635 \\
.174 \\
.236 \\
.476 \\
1.28 \\
.114 \\
1.05 \\
2.11\end{array}$ & $\begin{array}{r}.244 \\
.092 \\
.066 \\
.598 \\
.069 \\
.111 \\
.371 \\
.142 \\
.086 \\
1.36 \\
.354 \\
.935 \\
1.40 \\
.393 \\
.248 \\
2.48\end{array}$ & $\begin{array}{r}.000 \\
.072 \\
.109 \\
1.06 \\
.069 \\
.069 \\
.760 \\
.795 \\
.117 \\
2.03 \\
.955 \\
2.54 \\
2.23 \\
1.422 \\
3.53\end{array}$ & $\begin{array}{c}2.54 \\
.157 \\
.142 \\
1.55 \\
.141 \\
.067 \\
3.36 \\
.194 \\
1.55 \\
3.35 \\
2.66 \\
2.99 \\
2.84 \\
3.00 \\
.995 \\
3.36 \\
4.38\end{array}$ & $\begin{array}{c}3.72 \\
1.04 \\
.485 \\
3.45 \\
.916 \\
.134 \\
3.66 \\
.582 \\
.104 \\
4.41 \\
3.68 \\
4.20 \\
4.17 \\
4.35 \\
3.08 \\
5.00 \\
6.50\end{array}$ \\
\hline
\end{tabular}


TABLE III: WOIATUR PIOKUP RETAIIIE DURING A GEVM DI DRTIYC PERIOD

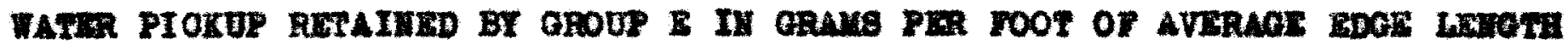

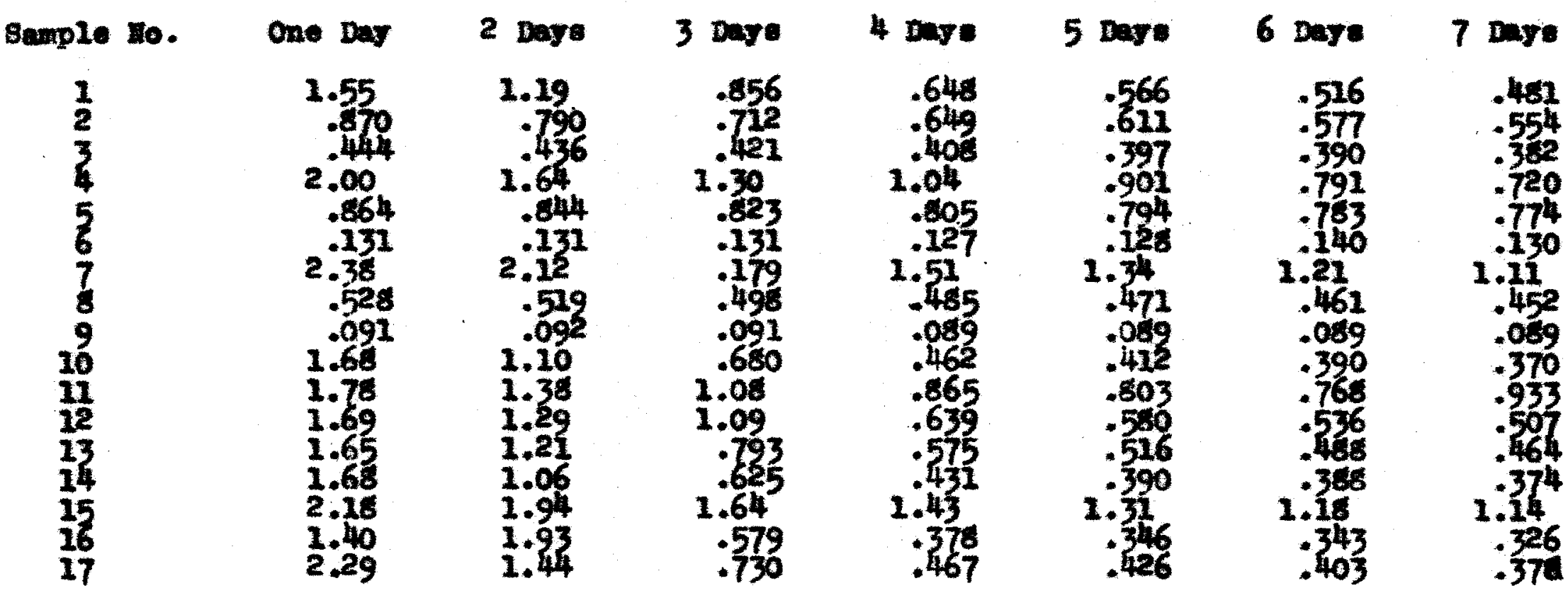




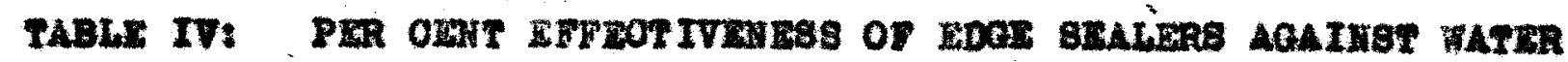

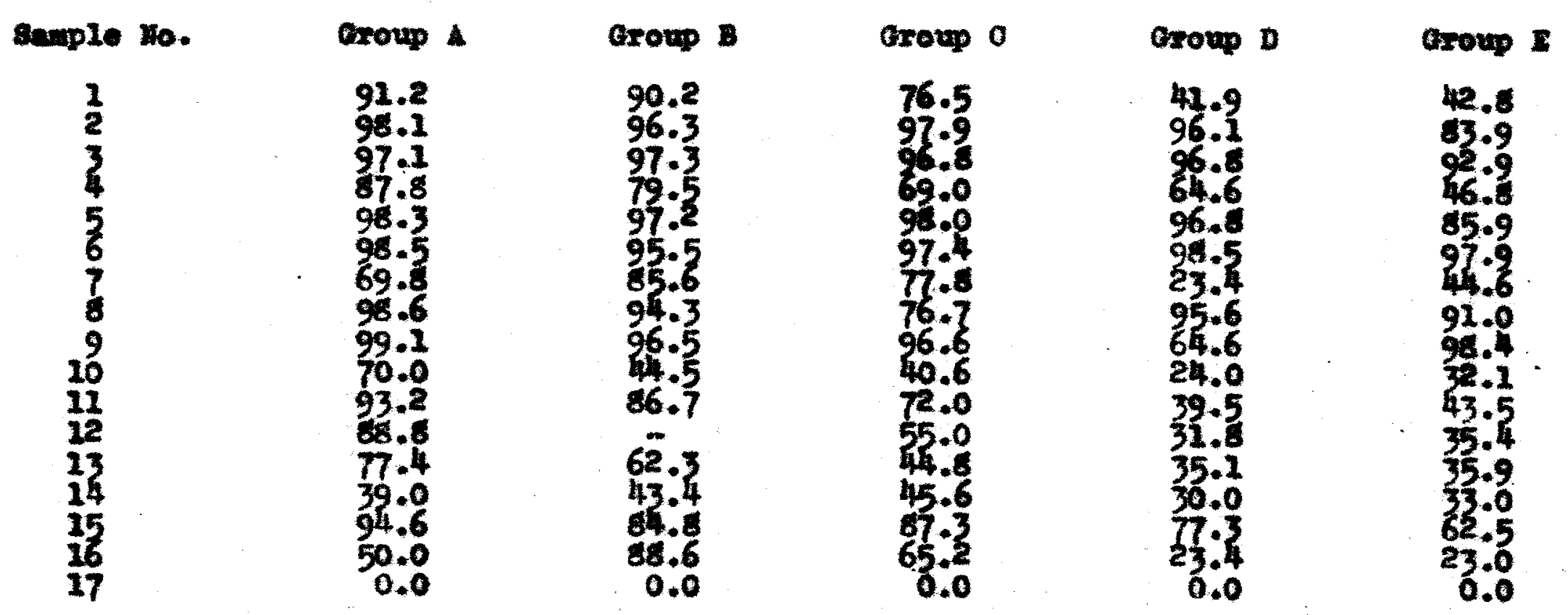




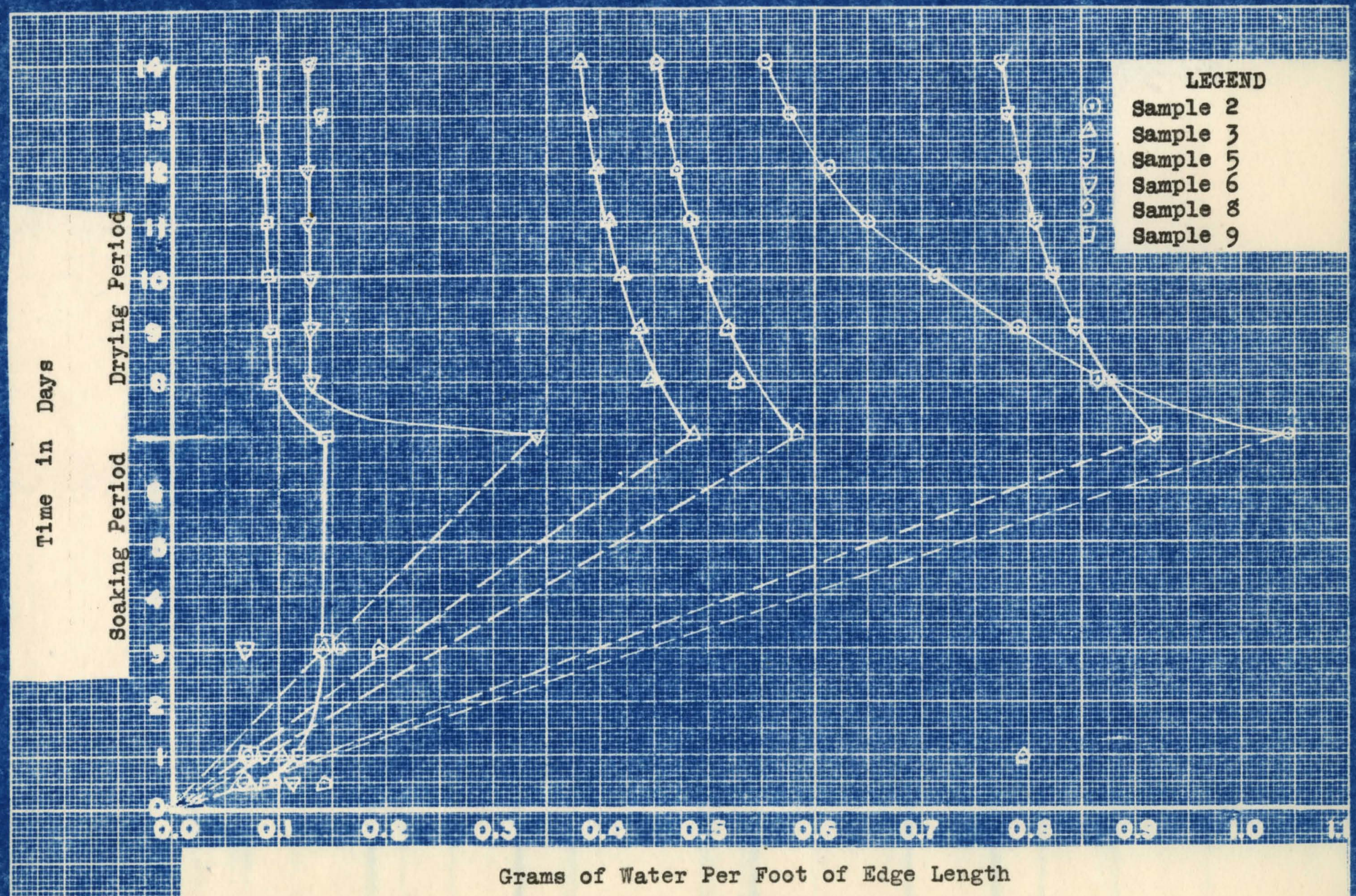

FIGURE 1: MOISTURE PIOKUP OF EDGE SEALED WOOD SAMPLES (1) 


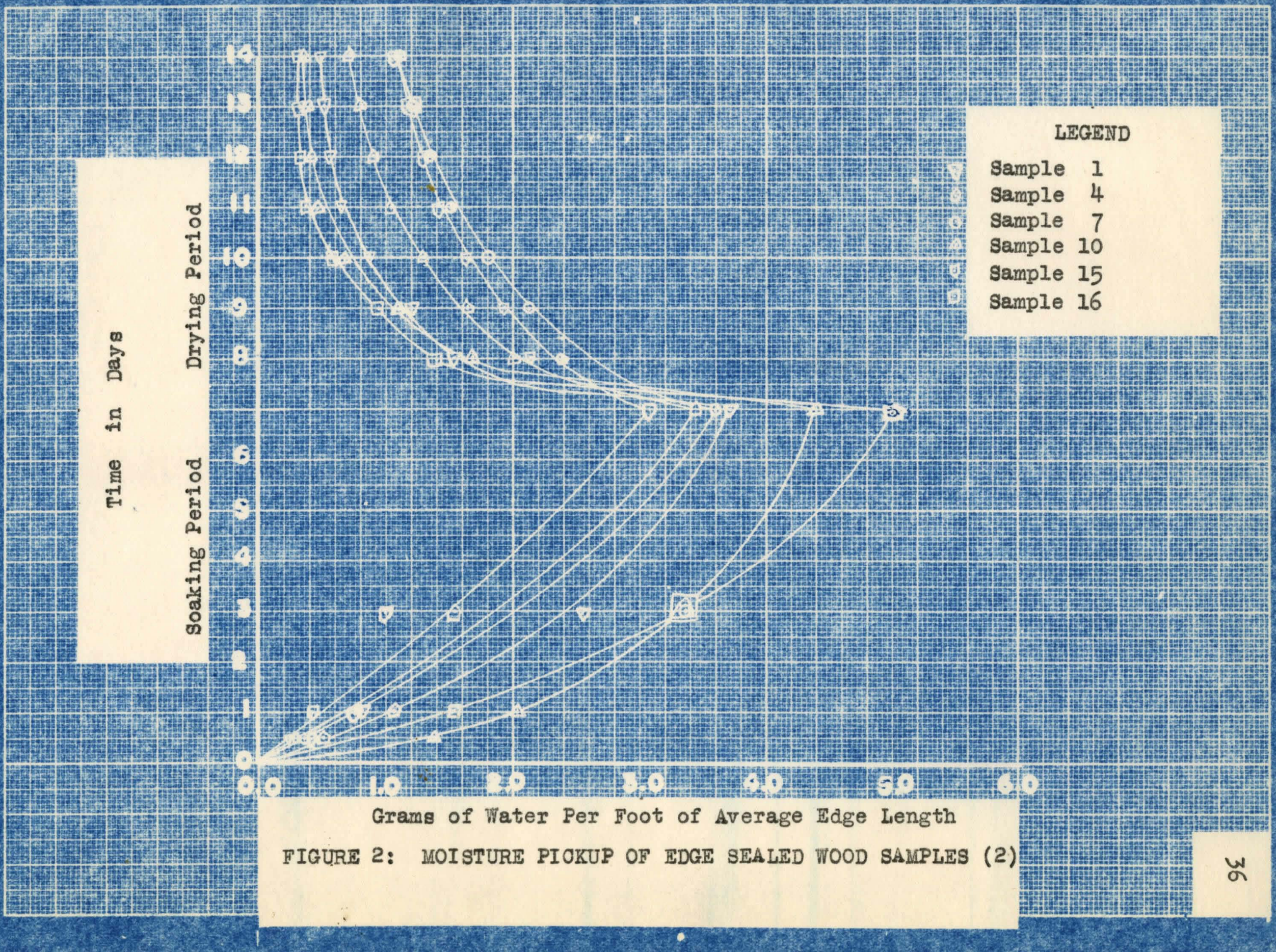




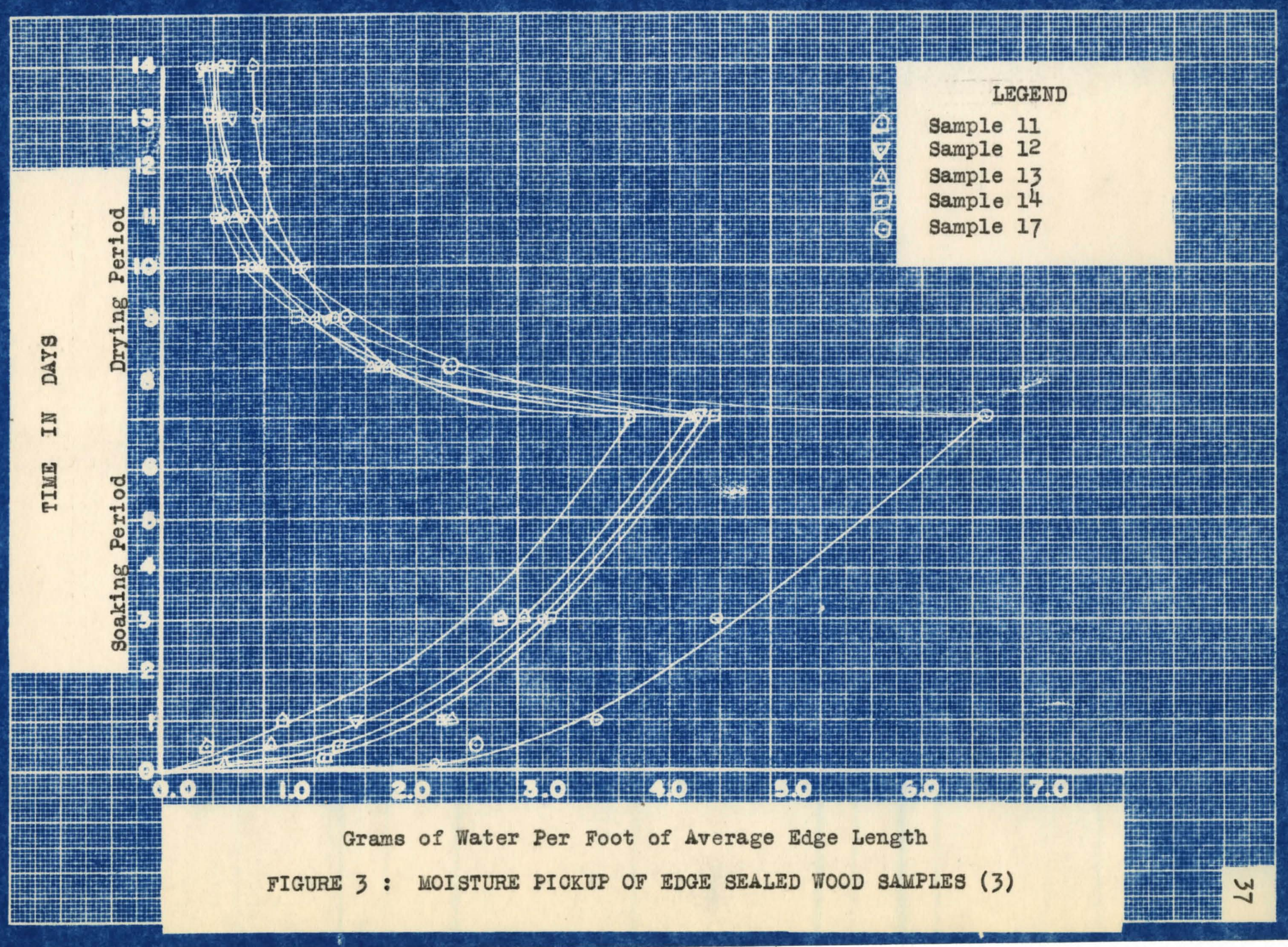




\section{Dinouston}

Frandation of the reoults and ourves juet presented revealed man diserepuneles in the soaking ourves. Thore were two probable errore in the seaklag ourves.

1. A esparate wod eample wa bed for each soaking porlod. It was considered Imposible to obtain wood samples that wexe ontirely unlform.

2. In coating ouph of the fire samples for a given eample molature barriex, it was almost imposelble to maintaln

a miform filn thioknese.

These conoluetene wore berne out by the faot that the drying ovives shor faz greatex preolaton than the coaking ourves. It w11 be remenbered that enoh of these ourves was plotted from dat taken on a single eapple. Howerer, the proolston was sufflelent to how the quniltative resulte that were dosired.

Ixam nation of the omamel soaking ourves reveale the following:

1. So the nuber of coate or fIIm thioknose was inoreaged the anount of noletrure abeorbed dooreased rogerdiess of the plgment coneontration. Howerer, thle deorease beoume unallex as the number of coats 1 nezeased.

2. Is the pigneat conoentration inoreaged, the awount of wloture aboorbed at any tiw deoreased. It way real1 sed, however, that this oonelualon had 11mitations above oortaln minown plgeont conoentration. 
3. The pleant in a molotaw barrter of thic tro played

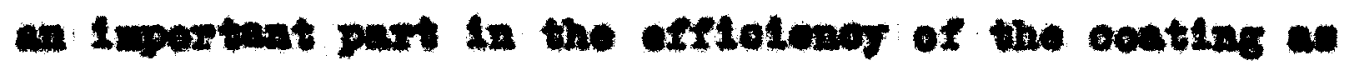
was ordemeos in the alfermen in extetenor of the

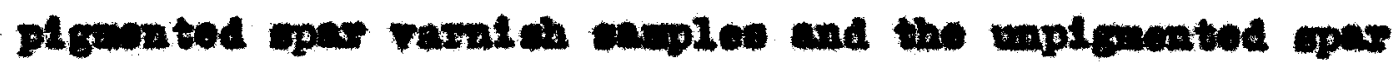
ront on (emple ten).

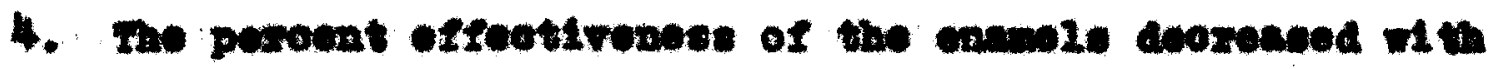
tho inoreare in sonting tine.

of the othor saplen, the solleming conoluntone nex reached:

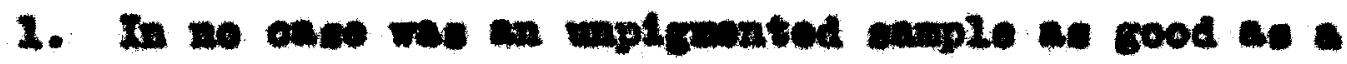
pignonted enple.

2. The wothod of ouring the phopalle varalan bad lithe afteot on ite efreativenous.

3. The strompt to exteot a eal of the reod oolle by Imporantion and polymoxtration of ramich we not mecesaru.

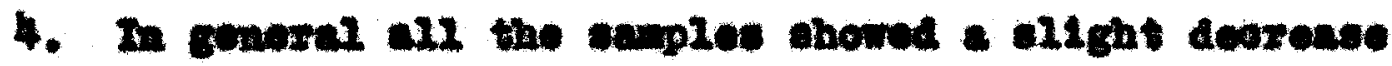

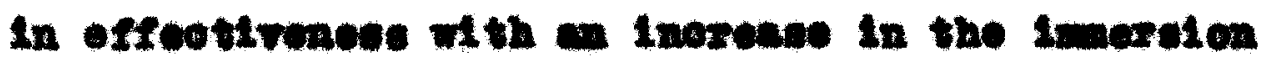
then.

Dundnation of the arying oures revented the followingt

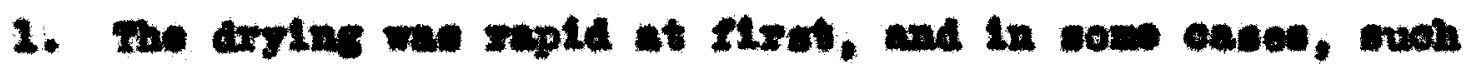

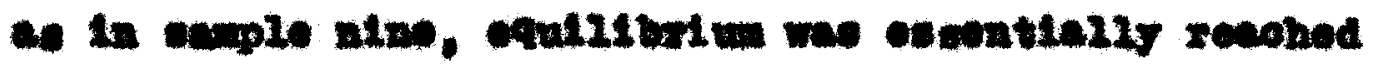
th the and of the dering partod.

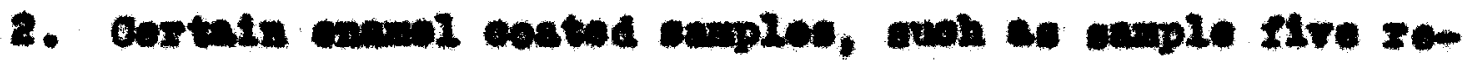

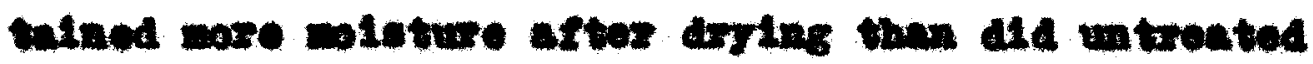


reod. This wat a hatereale effeot and will multiply 1teelf comowhat on furthor soaking and dxyling. Thlo oondition, of coures, was undesirable. As polnted out In the theory, certaln berriers ohow this effect. In weleoting the bent anagle this offoot was kept in mind. If the barrier doos not allow sufficlent reloese of the

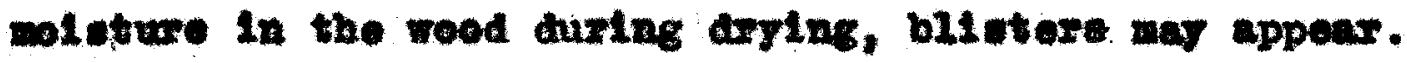
3. Wone of the samples dried to 1 te original walght al though in nang oaces oquilibrim was dert nitoly resohed. sinee the best per oent effectivenese was strom by the 40 pox oent plgnont epax varniohos, in elther the throe-oouted Exoups or the tro-conted groupe, the veleotion to be mede ras between ustag two or three coate of this enamel. Since the two-0oated sample wes almoet as affeotive as the three-ookted anule, sample elght was chosen beoauce production tim could be saved. 


\section{B. Vapor Reel stanoe Tost of Buanol later Barriese}

In certala weetion of the country an odge voder would be subjeoted to high humidty conditions. What offoot the mund al would hare on the barrlers wat not certaln. Although, thooretleally, the barriexs abould restat water veper to the wane degree that they resinted water imeraion, the four boat barlexw were taken from the provlowe teot group and ubjeotod to a vapor reatstance teat. Sinoe the results vieze to be essentlally quall tative with reopeot to untroated wood and to expedt to the work, a qutek and simple test wee ueod.

\section{Appexater}

A vacuram drylng oren, with rolume of about $1 / 2$ ouble foot herlng a therwostatio control, wes beleoted for the teat ohember because it was alf tight. An analytionl belanos wes ueed for wolghing.

Brocedine

sauples of 1/4 ineh, 3 ply, Douglas 11 plywood were out and sanded to about $4.7 \mathrm{om}$. wquare. The, as rot, intreated wood camples were pleced in the oren orer a saturated colution

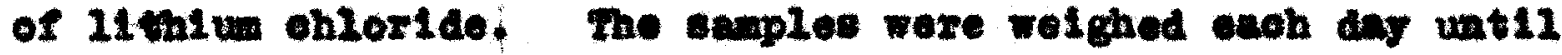

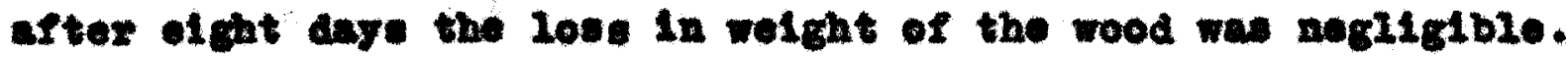
The boleture content of the wood wes, then, in cqullibrive with ats at $25^{\circ} \mathrm{O}$ at 15 per cont relative huldity."

-The relative hunidity matntatned by a esturesed salt oolution at a IVen temperature was obtalned from the Internationnl Oritloal Tables, Volum $I$, page 68. 
The exples were eated on thols edges of th their foopee-

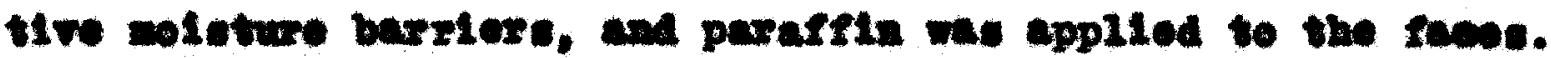

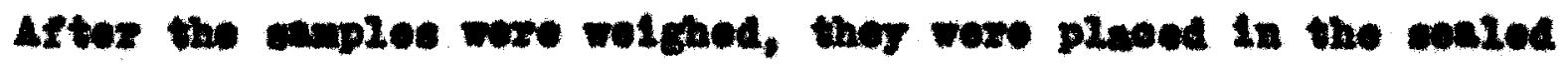

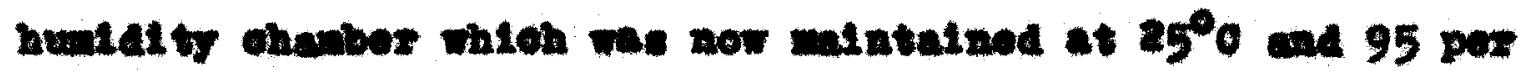

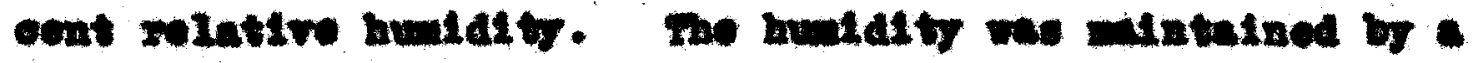

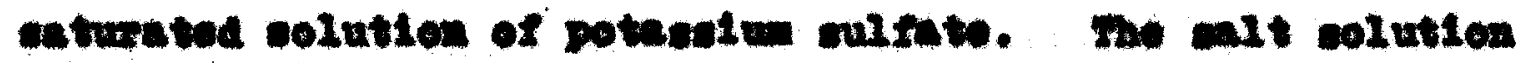

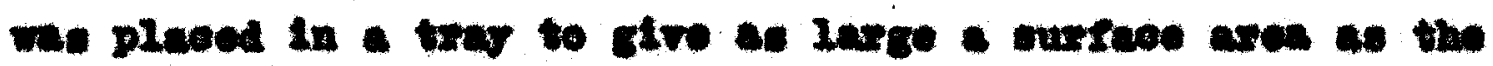
ouscos wovid pornte.

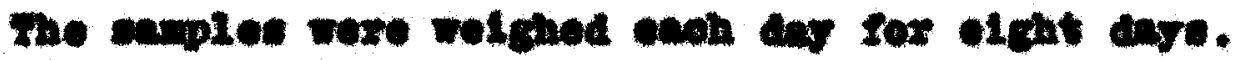
ravens rate:

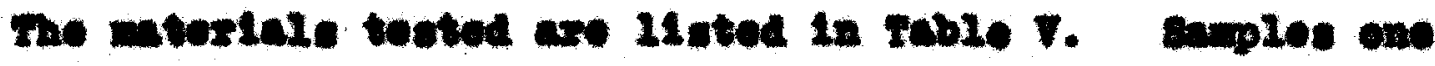

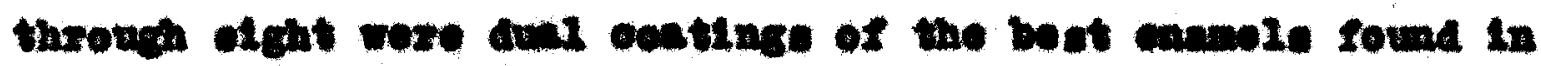

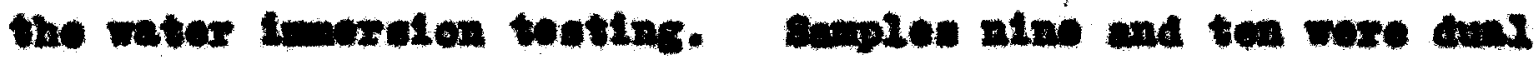
Dlenke.

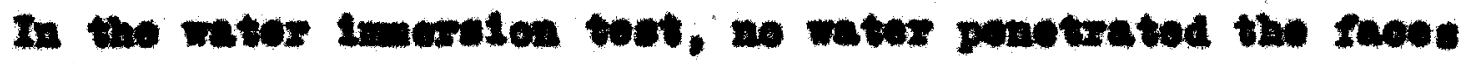
of the wood saples. Howner, in the ted water voper was

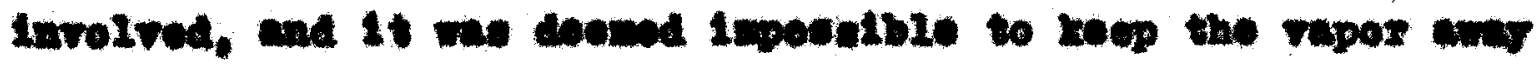

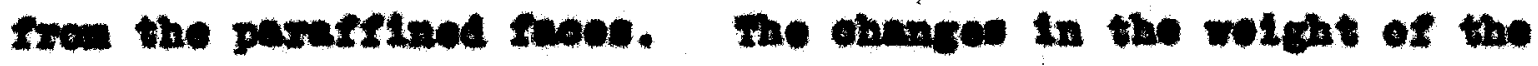

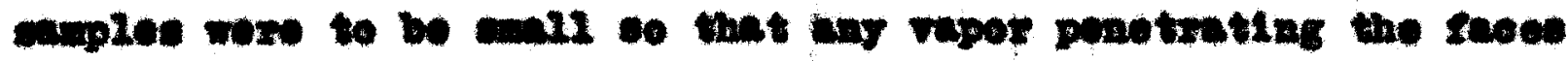

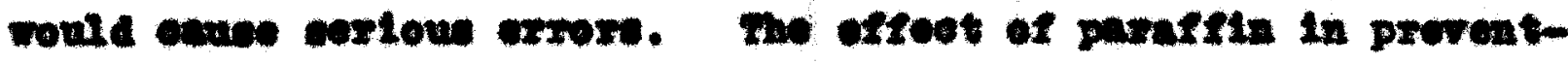

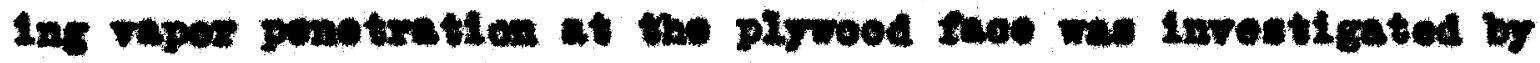

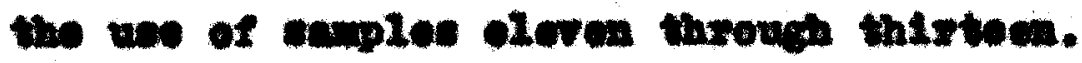
Dints

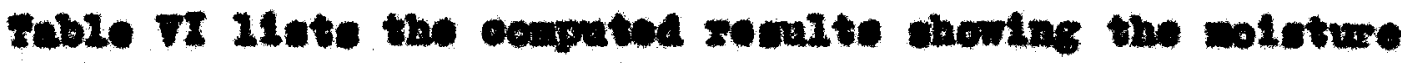

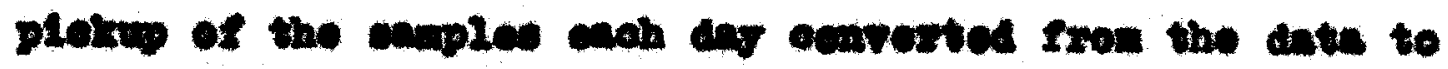

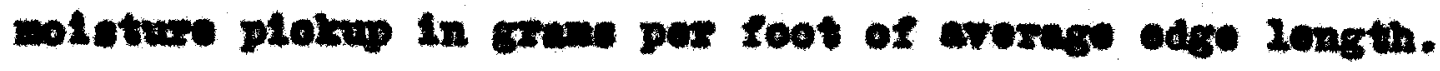


TABEs v: COMPOSTTIOI OF EDOE BEALERS USED II A VATER VAPOR TEST

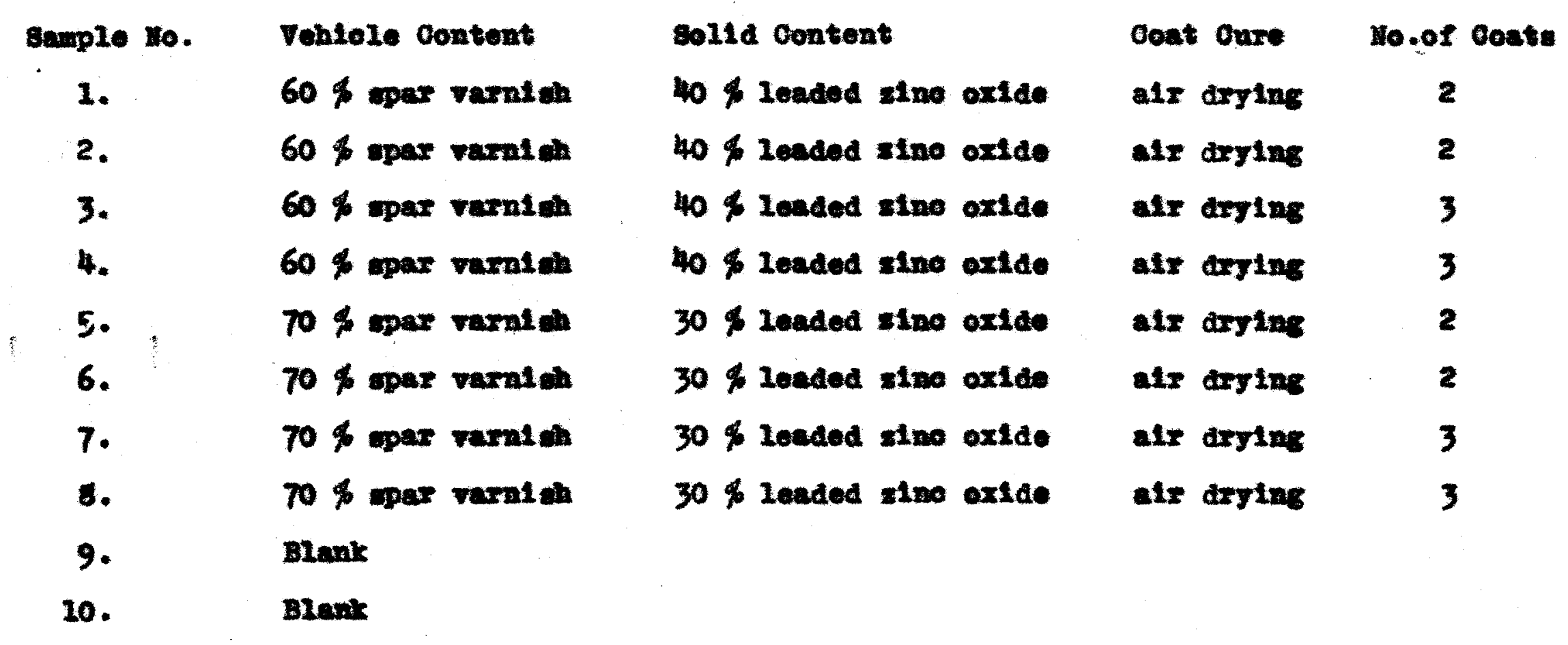


Pable VII Ilote the remute In' terme of per oent effoetivenose of the molature rapor as oompared to blank wood. Figure 4 1. a plot of Tabie III choming the gain In welght of the vamples verous time. Oniy one oure we plotted for the dusl samples belng en averege of the twe reevita. The expexinontal date are listed in Appendix B. Deseneter

The ability of the paraffin face seal to keop wol sture from penotrating the wood faces was unknom. With the ald of the data taken for the purpose of dotermining the offect of the som. caleulations Indioated that, oseentisliy, the ceal was satiofactory.

Although the samples eleven through thirteen vere welghed each dey durlng the tent, the folloming oaloulations were made on the bats of the first ar' walghing. This was done becanse the rate of wolature ploku was greateat at this tim; 1.0. the wood was at ite farthent polnt from equilibriun and a true condition oxisted in that the rapor panotrating the edges was not interfering with thet ponetrating the faece. The experimental resulte for samplos eleven through thirteon are 21sted in Table VII.

The caloulation were wade uning the origlnal data becase convexting to s foot of edge length woyld double the edge length but waxe the face area elght tines 1 to original area. In following the caloulations refer to the zeoult in Table VIII by thelr reepeotite sample numbers. 
TABLE VI: WATR VAPOR PIOKUP OF EDGI SELLED WOOD

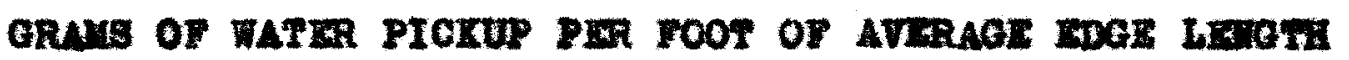

\begin{tabular}{|c|c|c|c|c|c|c|c|}
\hline Sawple ro. & $1 \mathrm{Day}$ & 2 Day & 3 Bare & 4 Dare & 5 Dare & 6 mare & 6 Daye \\
\hline $\begin{array}{l}1 \\
2 \\
3 \\
4 \\
5 \\
6 \\
7 \\
8 \\
9 \\
10\end{array}$ & $\begin{array}{l}.0300 \\
.034 \\
.020 \\
.038 \\
.055 \\
.046 \\
.037 \\
.052 \\
.466 \\
.425\end{array}$ & $\begin{array}{l}.058 \\
.061 \\
.044 \\
.079 \\
.125 \\
.093 \\
.076 \\
.043 \\
.661 \\
.622\end{array}$ & $\begin{array}{l}.080 \\
.071 \\
.067 \\
.110 \\
.157 \\
.147 \\
.100 \\
.063 \\
.773 \\
.741\end{array}$ & $\begin{array}{l}.099 \\
.100 \\
.068 \\
.133 \\
.190 \\
.161 \\
.121 \\
.076 \\
.875 \\
.832\end{array}$ & $\begin{array}{l}.116 \\
.117 \\
.069 \\
.157 \\
.227 \\
.195 \\
.145 \\
.093 \\
.951 \\
.071\end{array}$ & $\begin{array}{l}.140 \\
.135 \\
.071 \\
.191 \\
.268 \\
.243 \\
.175 \\
.117 \\
1.01 \\
.954\end{array}$ & $\begin{array}{r}.185 \\
.165 \\
.075 \\
.247 \\
.342 \\
.295 \\
.224 \\
.153 \\
1.11 \\
1.01\end{array}$ \\
\hline
\end{tabular}




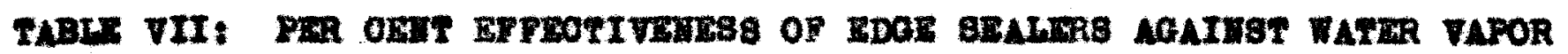

\begin{tabular}{|c|c|c|c|c|c|c|c|}
\hline Eample no. & 1 pay & 2 Days & 3 pare & 4 Dave & 5 Dare & 6 Daye & 8 Dar. \\
\hline $\begin{array}{r}1 \\
2 \\
3 \\
4 \\
5 \\
6 \\
7 \\
8 \\
9 \\
10\end{array}$ & $\begin{array}{l}93.2 \\
92.2 \\
95.5 \\
91.3 \\
85.3 \\
89.5 \\
91.6 \\
95.1 \\
0.0 \\
0.0\end{array}$ & $\begin{array}{r}91.0 \\
90.5 \\
93.2 \\
87.7 \\
80.5 \\
95.6 \\
88.2 \\
95.7 \\
0.0 \\
0.0\end{array}$ & $\begin{array}{l}89.4 \\
90.6 \\
91.0 \\
85.4 \\
79.1 \\
80.5 \\
86.7 \\
91.7 \\
0.0 \\
0.0\end{array}$ & $\begin{array}{r}88.4 \\
88.3 \\
92.1 \\
84.4 \\
77.7 \\
81.1 \\
85.9 \\
90.8 \\
0.0 \\
0.0\end{array}$ & $\begin{array}{r}87.3 \\
87.2 \\
92.4 \\
82.8 \\
75.1 \\
7.6 .6 \\
84.4 \\
69.8 \\
0.0 \\
0.0\end{array}$ & $\begin{array}{r}85.7 \\
86.3 \\
92.9 \\
80.5 \\
72.7 \\
75.2 \\
82.2 \\
80.1 \\
0.0 \\
0.0\end{array}$ & $\begin{array}{r}82.6 \\
82.6 \\
92.4 \\
76.3 \\
67.8 \\
78.1 \\
78.9 \\
85.6 \\
0.0 \\
0.0\end{array}$ \\
\hline
\end{tabular}




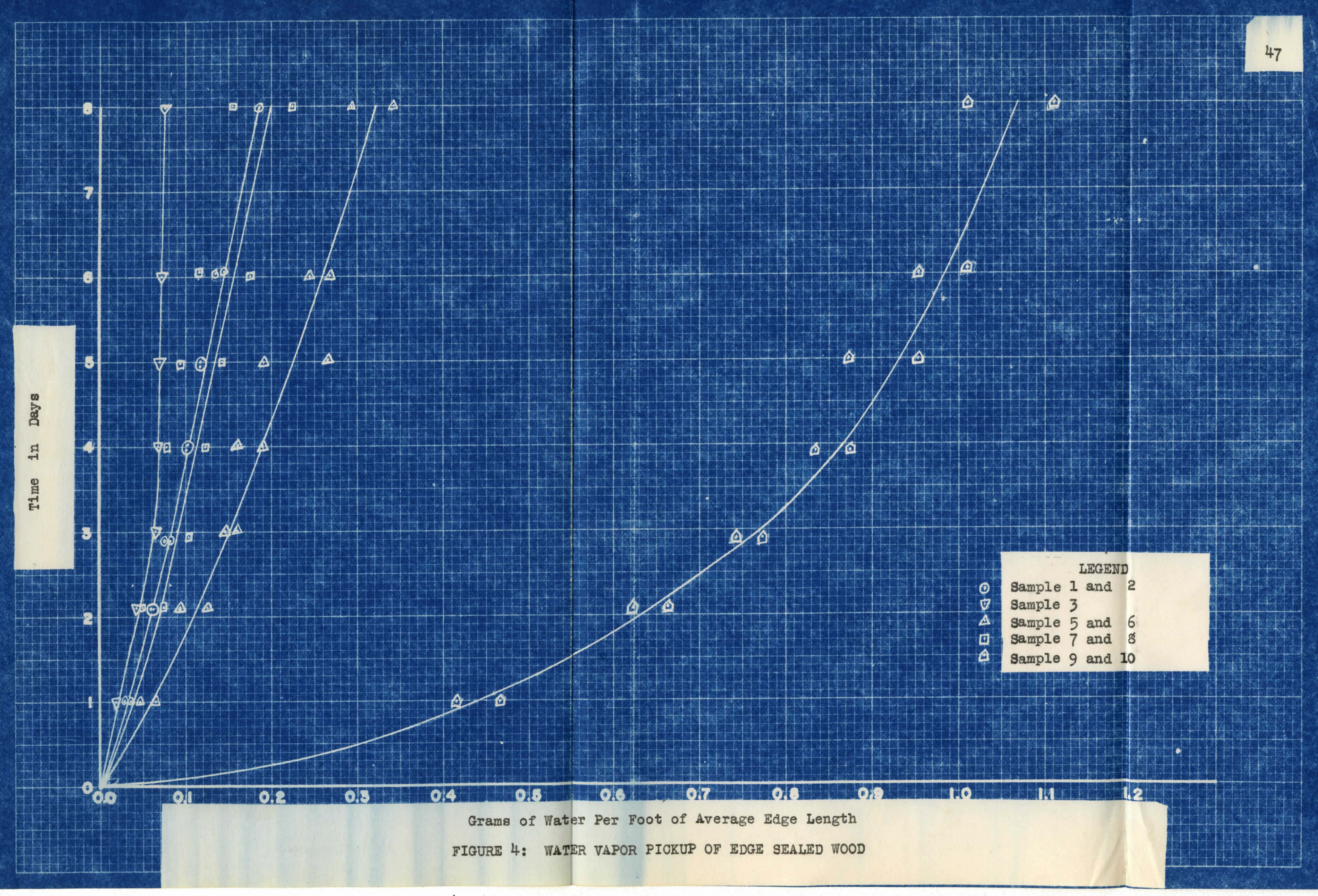


Oaloulation 21 gumple 12 atnus semple 12

0.0734 atnus 0.0101 equile 0.0633 gramin of rater

Caloulation 2: Sarplo 13 minus Sanplo 22 0.2680 ginue 0.0734 equal. .1646 grams of water

Deloulation 1 represente the reduotion in wolsture plokup due to face sealing with parafin, Oaloulation 2 represents the seduotion in molotrue plokup due to odge senilng. The assuption was wad that the ratio of the mols ture plokup through the edge to the plokup through the face of a completely aealed tamplo was dirootly pzoportional to the ratio of onlouistion 2 to oaloulation 1. Mocordingly, this ratlo was $0.2846 / 0.0633$ 0x, 31 that 2\%, 25 per cent of the molsture whioh penotrated sample Ho.11, penetrated through the parafined faoe. Thl: anount was 25 per cont of 0.0101 pam or 0.00252 grams, Reforring to Appendix B and avoraging the tro blank amples (9 and 10) after one day's expogure, the anount of molsture plokup was 0.2278 grans. Of thl anount, about 0.00252 grams should bo due to repor paealng through the face seal. Thle value was 1.2 per cont of the total gain in wolght and ropresents the error in Tables 6 and 7. For the purpose of this work the effect of moleture penetrating the feoes of the manples was necleoted. The erroxs in the resulte were

1. Inabllity to oontrol flip thloknone

2. Non uniformity of the wood andes

3. Vepor ponotration of the wood reoes. The errore were aspuned to be amll beoance of the exoelient 


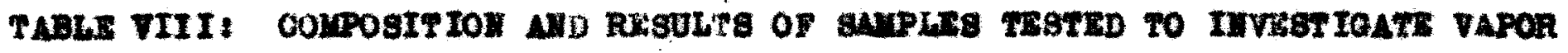
REgTstunos paRATH sabs

Earple Eo.

Composition

11.

12.

13.
A wood sample completels sealed with paraffin

4 wood sample edge cealed with parafrin only

A rood anplo oompletely meonled
Grame of vater vepox plokup after one day exponare

.0101

.0734

.2681 
remalte obtulned. However, eaple 4 was orldontly a poer

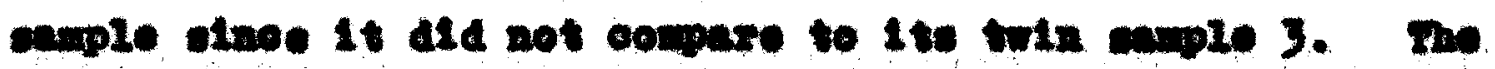
remulte obtelnad for caple 4 nove regeoted and not plotted

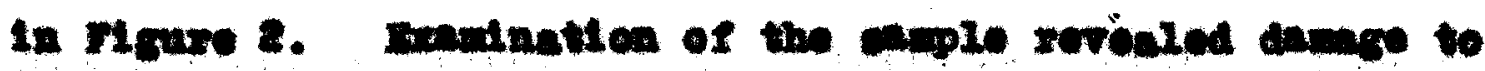

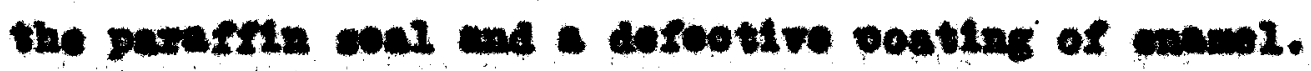

brometien of reble $\mathrm{XI}$ and Hgure 4 rowelod the following oeneluticnet

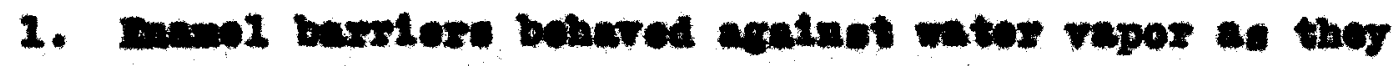
Ad eratinet meres.

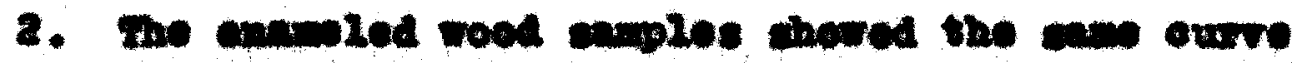

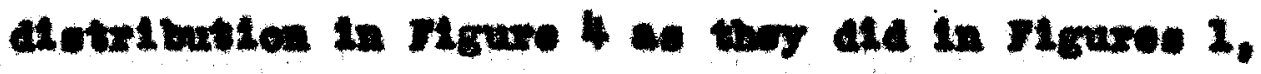
2. and 31 1.e. of the plement oonoentratlon and

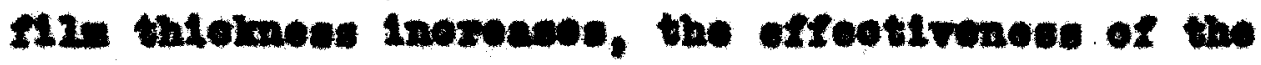
ootting increane.

3. At the time of exposure Inoreaned, the offodtivenose seoreseed.

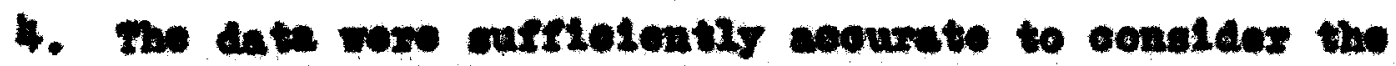
tect conezutre. 
0. Watex Imweration Test of Watex Barriers

At this polnt, the epenter opoelfied that bo dealred the edge socler to meet the prodwotion drying sohodule of the Connison Plant. The produotion cobodule ellowed for an

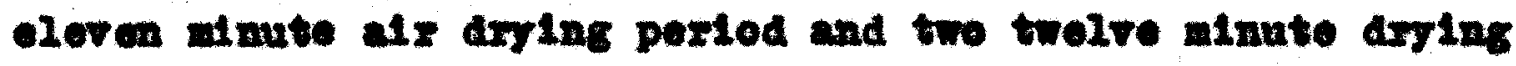
perled at 12005. After attempting, wthout good roeulto, to quifoken the drying rate of 40 per cent leaded sine oxtde,

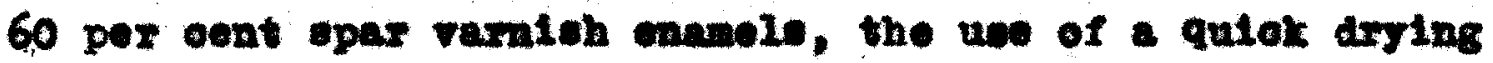

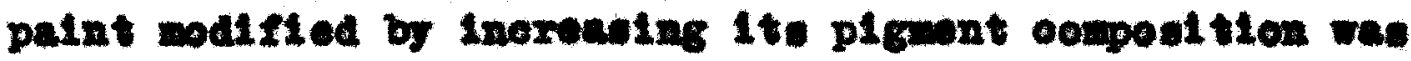
Invertigated. Shoh a coating bhould be suovesoful agetnat water inmexelon sibe the bele composition would be almilar to that of the previounly teeted enamele.

\section{Spmatrat}

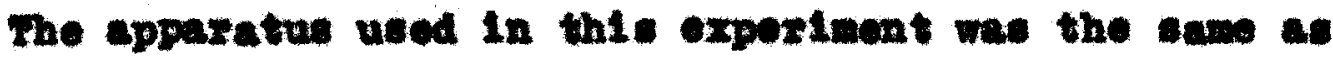
that ued in the firet water immerution toot. Procedre

The wood camplec were out and propared as in the previone Imeeretion test. However, a epeolal oodting applioation wes uned. The test ceatinge were applied of th a brum to a thicknees of one coat followed by an eleren-minute dry ing porlod. An unodurterated oost of Azoo primox palnt wer oprayed on followed by a ten minute erying pertod at $120^{\circ}$ r. Thon anothor unadultextod spray eost of Aroo pximex palnt was applied folloned by a twelve-minute drying pertod at 120\% F. Th1s prooedure, was cally adaptable to the ounnieon preduetion wobedule. In in the proviow water lwueralon test, throe groups of bach sampls 
to be tented were propared.

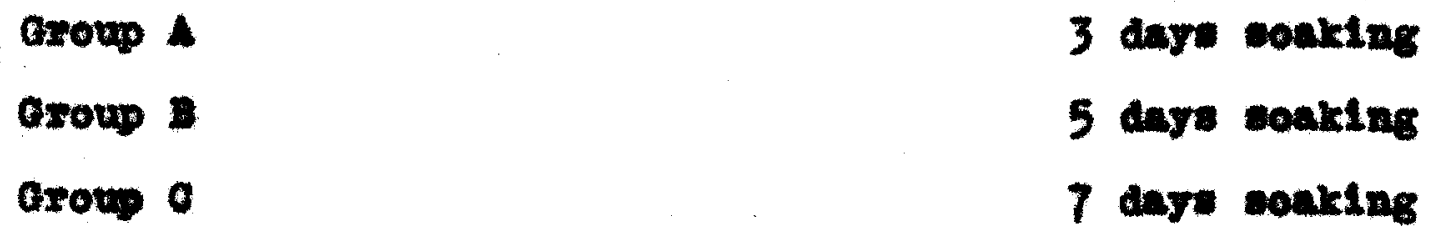

The samples ware paraffined, wolghed, bundied togethor, and immersed in water. The materiale teoted are lieted in rable x.

Reavits

The experimental date were ooprented from gram of noleture plokup to grans of molature plokup per foot of arerege edge longth and wore tabulated in robloe $X$ and $X I$. Fable $X$ givea at the wolght of moleture plokup by the eamples por aly while Table XI expreases Table $x$ in per cent effootivenese. Figure 5 is alot of rable $x$ showing grame of water absorbed per dayfoot of avernge edge length vorau tim. The experinontal data are listed in Appondix B. Dinoverton

It we orident from the reaulte dhown in rable $x$ thet the sooursoy of this teat was not as good al previous work. For Instanoe, maple 4 bhowed an axtromely 100 offoctivenese, in

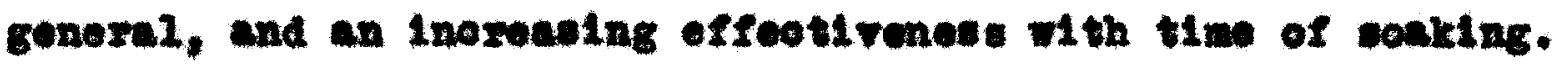

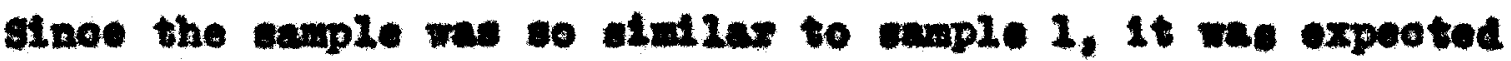

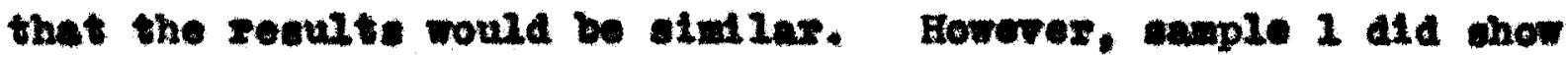
exoellent rosults and we recomended as a fat dxy Ing nolsture barriox for odge senling. If time had permitted, a cheok of sowe of the reevite w th another toat would hare been dealrable. Howerer, the reault obtalned for eample 1 would have varted 11tเ2e. 


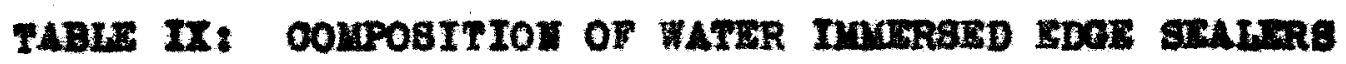

\begin{tabular}{|c|c|c|c|c|}
\hline Bample No. & vohlole Oontent & Solld Oontent & Dost oure & No. of ooate \\
\hline 1. & $66 \& 4$ xoo primor & 3h \& losded atne exide & atr arying & $\mathbf{1}$ \\
\hline 2. & $66 \&$ sroo primer & $34 \$$ sino oxtas & atr arying & 1 \\
\hline 3. & $\begin{array}{l}60 \text { \& hoat rosiotive } \\
\text { phomollo rawith }\end{array}$ & 40 \& Ieaded stine oxtde & elx arying & 1 \\
\hline 4. & $75 \neq 1 x 00$ pxtmox & 25 \& leaded stine oxide & ar drying & $\mathbf{2}$ \\
\hline 5. & Blank & & & \\
\hline
\end{tabular}

- Aroo prinar - Aroo Paint Ho. 156 Aroo Palat Oowpany, Oleveland, Onto 


\section{TABH X: GAIX IH WOTGTUR CONTEH OF BDEE GLALID WOOD}

Grans of Vater per Foot of Avorage Idge Longth

\begin{tabular}{|c|c|c|c|}
\hline Eample Ho. & Group $A$ & Exoup $\mathrm{B}$ & Croup 0 \\
\hline 1. & .424 & .580 & .847 \\
\hline 2. & 1.66 & & 2.50 \\
\hline 3. & 1.06 & .748 & 2.36 \\
\hline 4. & 1.35 & 3.35 & 2.79 \\
\hline 5. & 4.24 & 4.80 & 5.96 \\
\hline
\end{tabular}

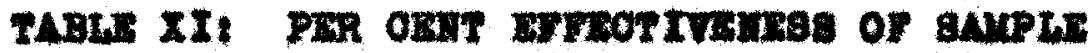
apor grulers

Bample No.

1.

2.

3.

4.

5.
Oroug 4

90.3

$\$ 0.7$

75.0

68.0

0.0
Group 8

86.0

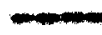

4.5

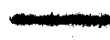

0.0
Group 0

6.0

58.1

60.4

53.3

0.0 

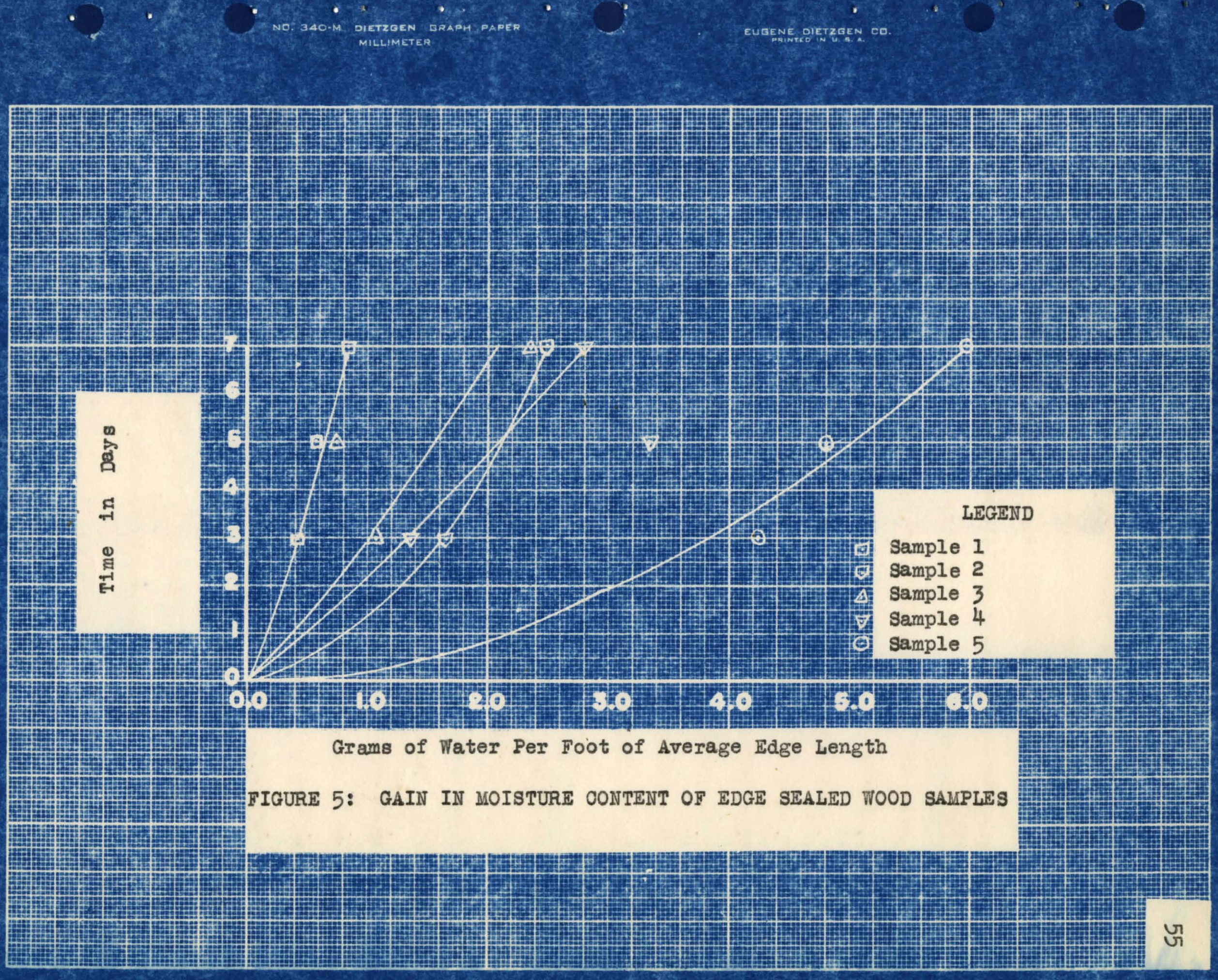


\section{Braluation of hater Vapor Barriers}

One of the probleme onoountered in modern houling of tight conotruetion is the condenation of wolsture in the atud epwolng. L. V. Teadale, of the poreat Prodnote Laboratory (7), gave the following explanition. Oortain trpes of modom houeen have Interior and exterlor eldes of the exterior wile of duplieato construction and meteriale. Consoquently, the rosletenos to the how of vepor through the wall is equally divided between the intexior and exterior olde of the wa11. 81noe the partlal presoure drop of watex vapor acroes any part of the wall is proportional to the recletenoe of that part of the well, the partial preecure of water vapor in the ctud apeing 1s an arerage of the watex rapor partial preseure on both aldes of the wall. During the vinter monthe, in houses of tight construetion, the room axe kpt at $72^{\circ} \mathrm{Y}$ and 50 par oont relative huatdity, oorreoponding to a partial preseure of 10.04 w of nexowy. Gulte often the outelde tomperatuze w112 be at $32^{\circ} \mathrm{Y}$ or lower with a relative humldty of 100 pex oent correapondIns to a partial presevere of $4.58 \mathrm{~mm}$ of marowy. Aserming the partial preanure of the rapor inalde the atud apacing to be an averege of the room and outelde partial presores, artial preseure of 7.31 mof morowy extete in the atud opecting. At temperaturee of $44^{\circ} \mathrm{P}$ or $10 \mathrm{wex}$ in the spacteg, wotsture would thon be oondenesd. This exnmple, of ooureo, Is mpothetical but presente a olear ploture of wat cotually happens. 
In houese built along older deelgne the condenention probleme raxely axe not beomune of the loose conetruotion of the extertor olde of the rall rooulting in 20 reotetanse to rapor now.

If a vapos bawles of sufflolent effeotivenese were to be pleoed alone the inteniox side of the wall, vapos condoneation rould be ellintated in the stud opeose. In Imvettgating poestbie barriers, cotunl rates of vapor alffuncion through wood

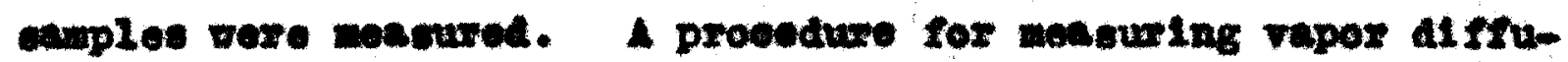

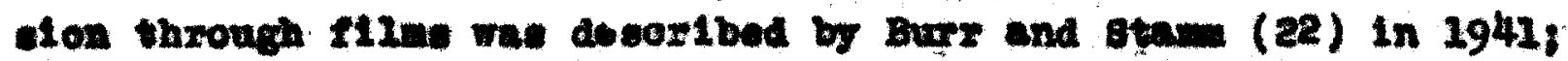
The epparatus we deelgned to gite maximan rates of rapex:

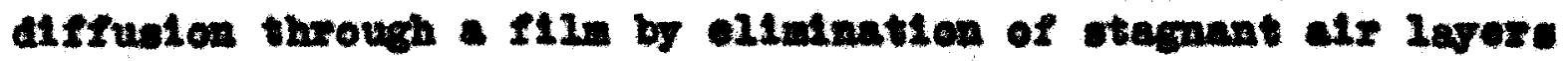
on olthw ald of the saple. I modifled opparatu, ualng the ear prinolples, we ued in the repor barilo investigation. Ampretin

A tightly oonutruated box $4-1 / 2$ toet by 2 fout by 2 feet ande Irom $5 / 8$ inch plyreod was wounted over a motor. The notor was comeoted by a belt drive to a obnet that entered the bottom of the bex at an angle of 75 dogreen wth she horleontel. Wounted on top of the phaft and Inste the box wa a wooden diak 15

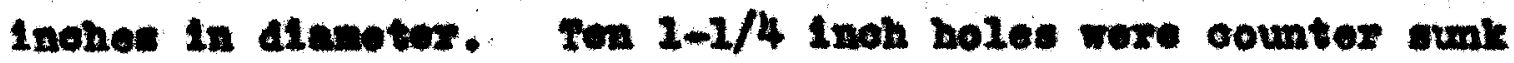
axound the rin of the atroular disk. The bolen served as reeelvers of the $100 \mathrm{ml}$ relghing botties. Aluatum stirsing soce coulpped with an alminum foll vane on the obank: wore wounted in the welghing boteles we that as the wooden disk rotated, the rode would owing as penduluna sgitating any solutione in 
the bottles and ofroulating the atr in the bottles. Thus, - wooden cample oould be sonled in the bottlos over a eatursted salt wolutlon and the stegrate als and 11quid flime in the soaled bottles ell minated. The box was oquipped with a thermotat for teaperature oontrol, a fan for alr alroulation, a pan of weter for humblty control, and a therwoneter well for wet bulb realinge, (see Mgures $6,7,6$ and 9 ).

\section{Prooedura}

The purpose of the equipwent just deseribed was to make posalble the eatabllohment of a constant water vapor partial preesure drop acrose a wooden dik. This was done by wans of exposing the oppost te aldes of the suples to differont relative humilities at the same texperature.

About 25 gram of an aqueous estrirated If thiun oblortde colution wa placed in the reighing bottles. Ended samples, 4.25 om in alameter, of 1/4 inoh, 3-ply Donglas 11x, plywood wexe coated with the teat rapor barriers and sealed in the tope of bottles with parafin. Great oare was wed in waxing the acal. The bottlos were then welghed and placed in the countersulk holee provlded. The top was placed on the bex, the thormowht wen set for $55^{\circ} \mathrm{r}$, and the motor and ran tarned on. The eamples were wolghed each cay when posalble. Thue, in the welghing bottles, the tomperatrure wad $65^{\circ} \mathrm{y}$ and the reletive humldIty we 20 pez oont. In the box the temporature was $65^{\circ} \mathrm{y}$ and the relative huldity was 100 per oont. 


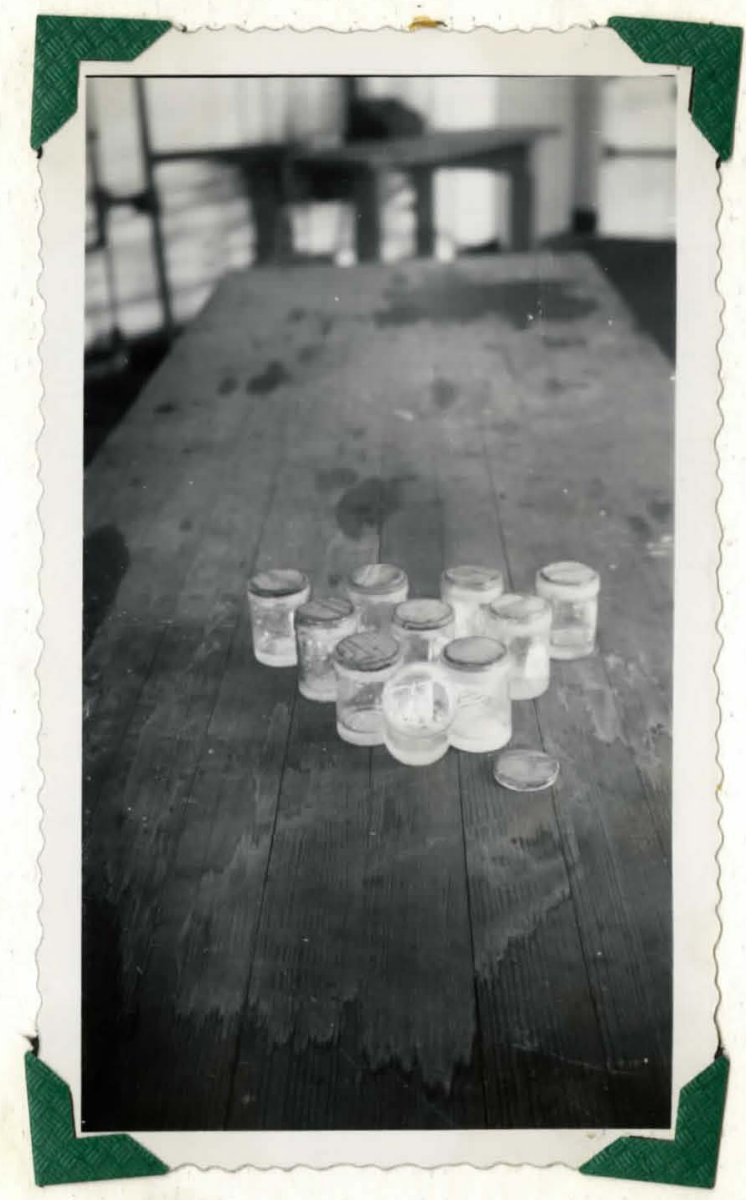

Digure 6. Ploture of Weighing Bottles (interior view) This figure shows the ten weighing bottles with the wooden samples sealed in place. The front bottle has been opened and tilted forward to show the stirzing rods. 


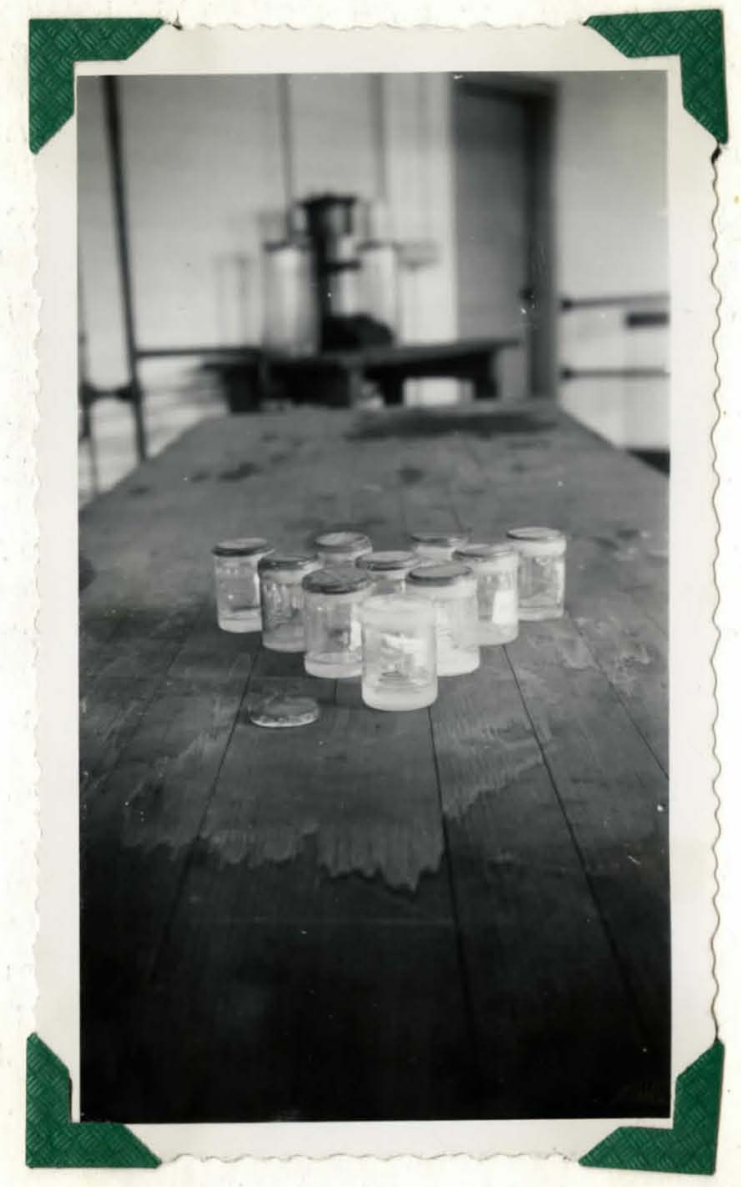

Migure 7. Ploture of Welghing Bottle (exterior view) This figure gives another view of Figure 6 . The stirring wid and aluminum foll vane are visible in the front bottle. 


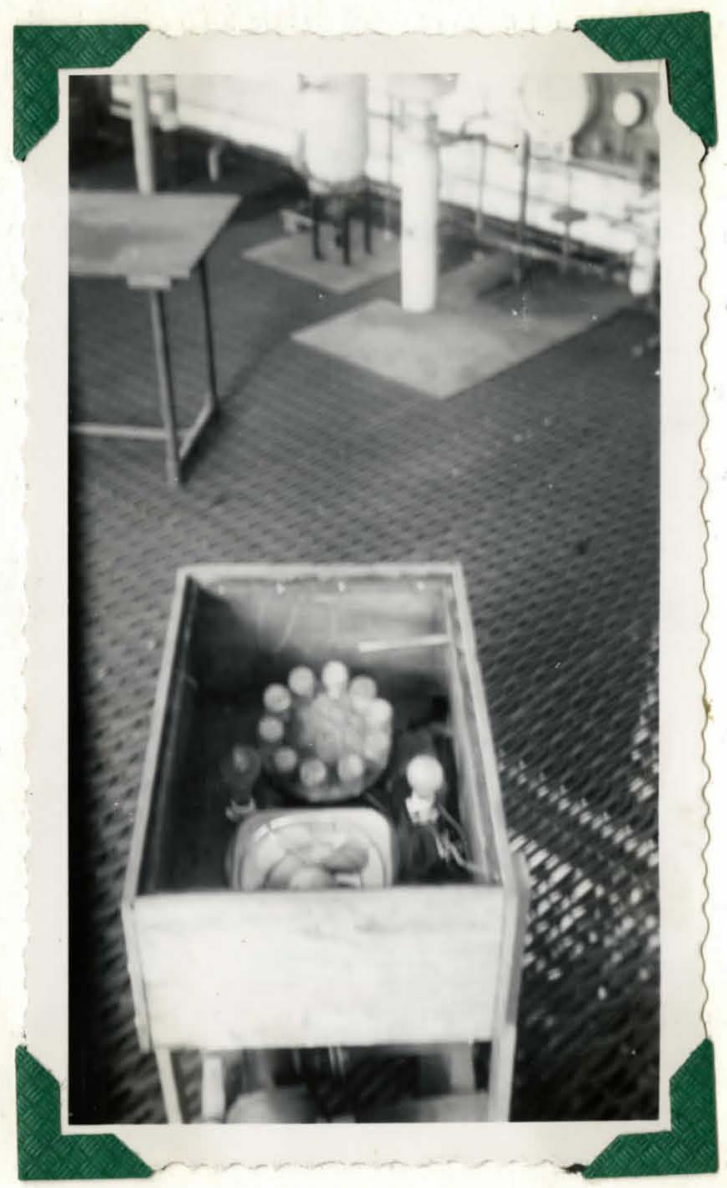

T1gure 8. Interior of Vapor Permeability Apparatus 


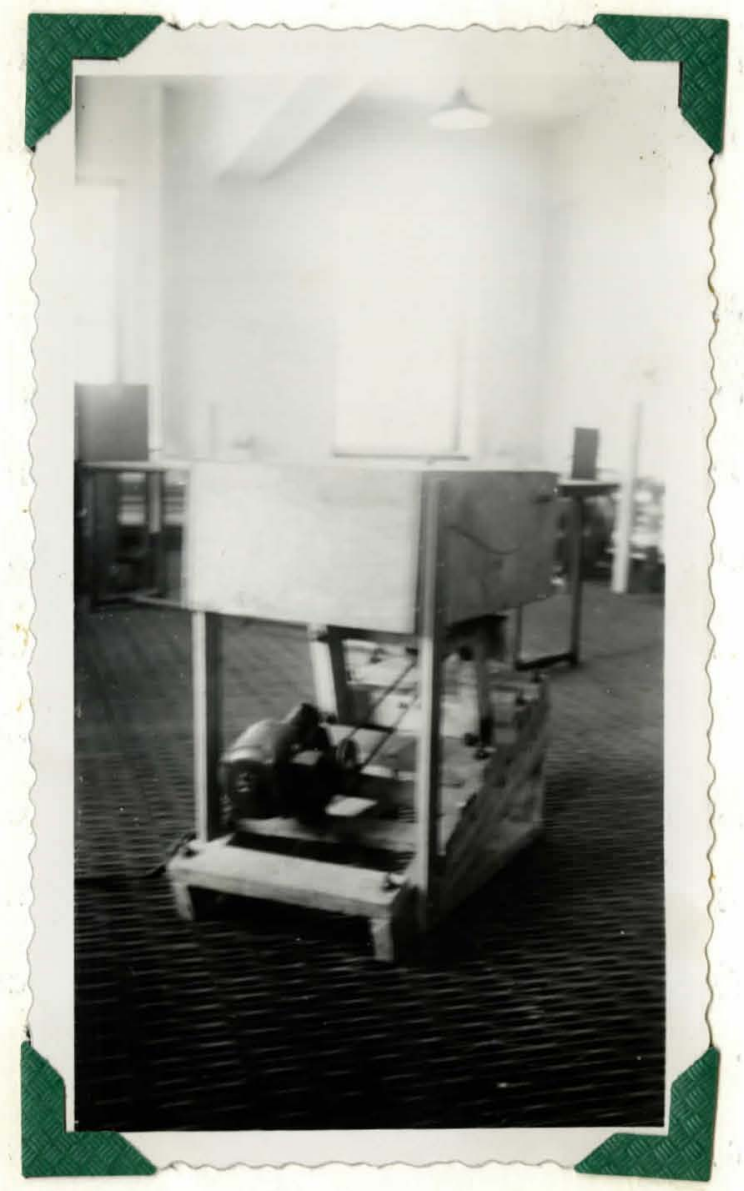

Tigure 9. Vapor Permeabil1 ty Apparatus Ready for Operation 
Materials Tested

The costings were applied to the faoes of the di ake. Five minute alx drying time was allowed between applioation of the suovessive obating. The material tested are ligted in Table XII.

peoulte

The gain in melght of the atuples during the 16-dey test pexlod are hown in Table xIII. In order to esloulate the rate of molsture diffuelon through the samples, Table XIII rae plotted a Figure 10 and 11. The PInal portion of the reeulting ourves wes the portion of the plot representing equilibrim conditions. At this portion of the ourves, the reolprooel of the elopes was oaloulated to give the rate of water rapor alffuston in grame pex day. This rate wa converted to the rate of watex vapex diffusion through the camples in grams of water diffueton per day and the reoults llated in Table XIT. Table XV was computed to show the resulte of labie XIV as per oent effectiveness of the coatinge. The oxiginal data is in Appendix B. Deouedon

The reavits of ample 4 should be rejected as an experimental fallure, alnoe thle eample showed a lexger rate of diffwaton than did untreated mood. Probably an Ineffeotlve weal eaved this exror. The theoretioal accuracy of the values listed in Table XIV were limited by the acouraoy of Figure 20. Other experimentere have reported resulta for anple 6 and 7 as high as 99 per oeat effeotivenoss. The wole reason for 


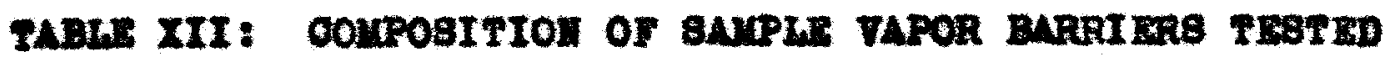

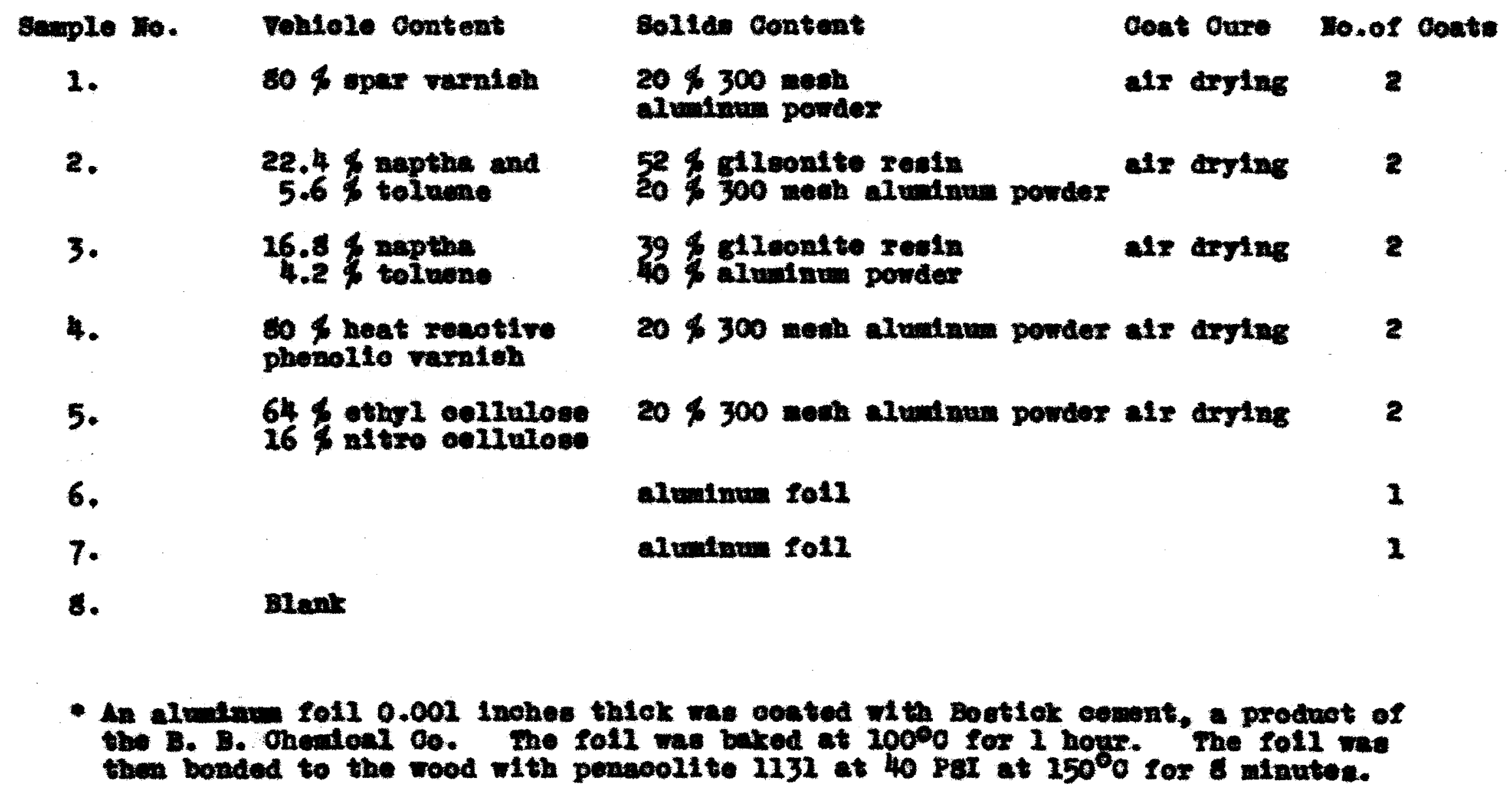




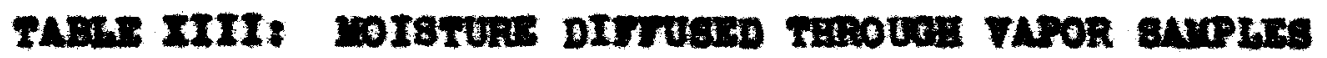

Axme of Water Btrunge

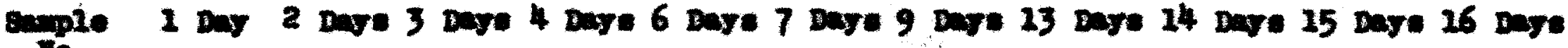
10.

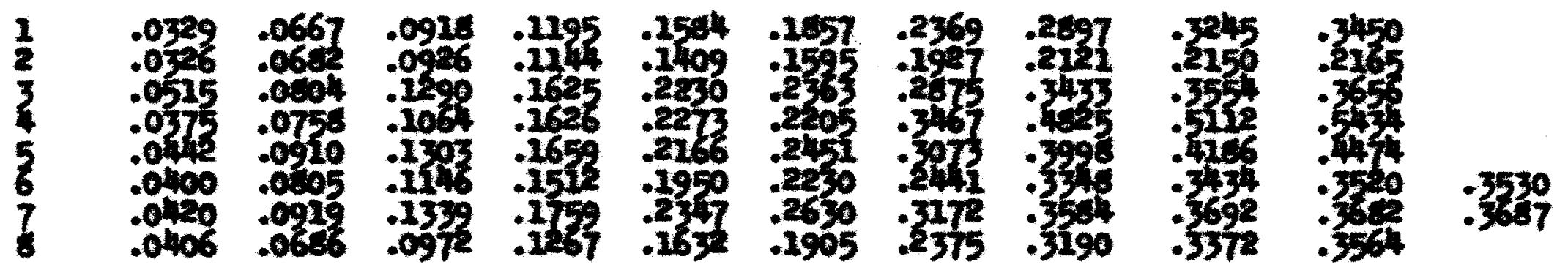




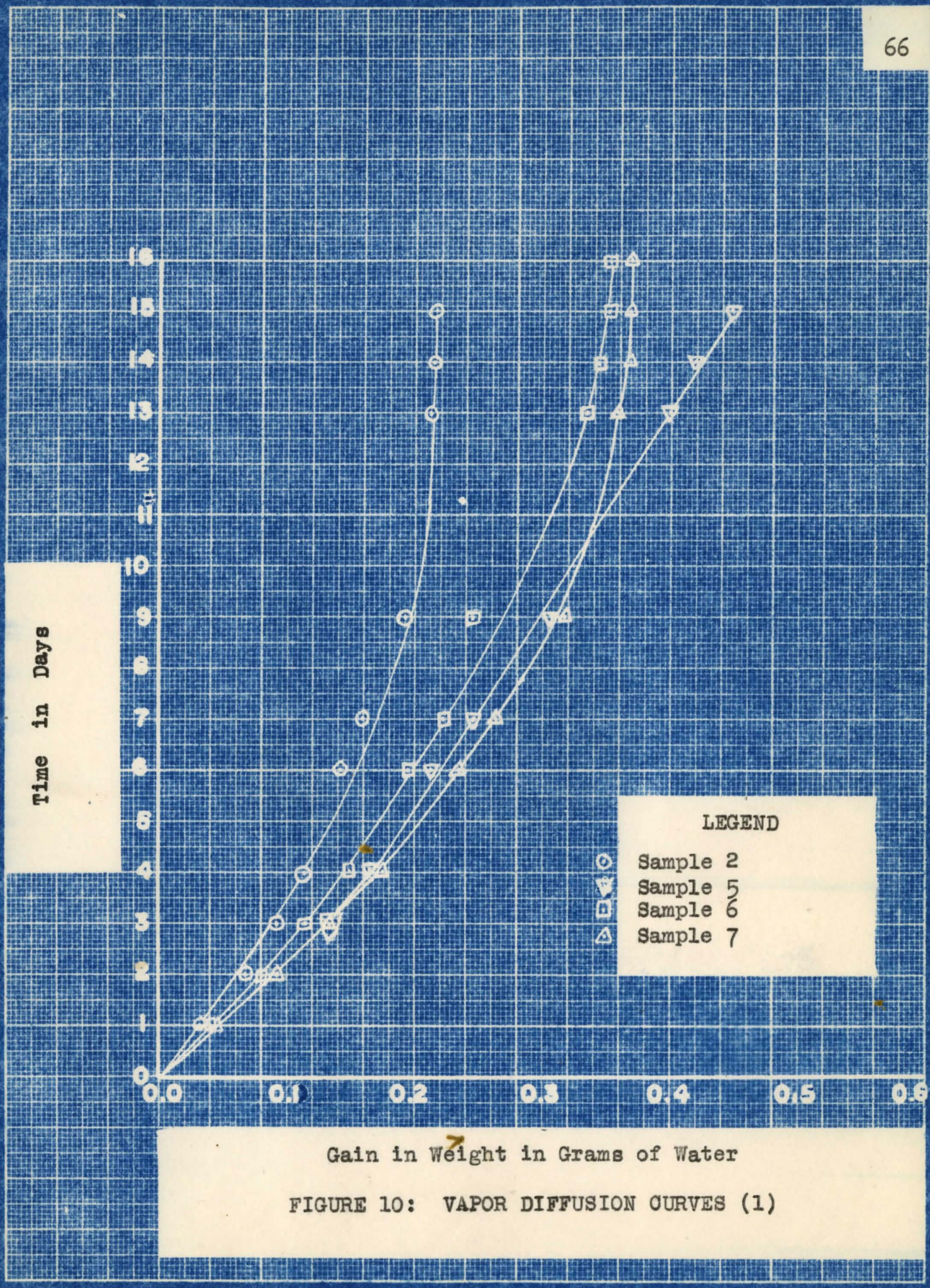




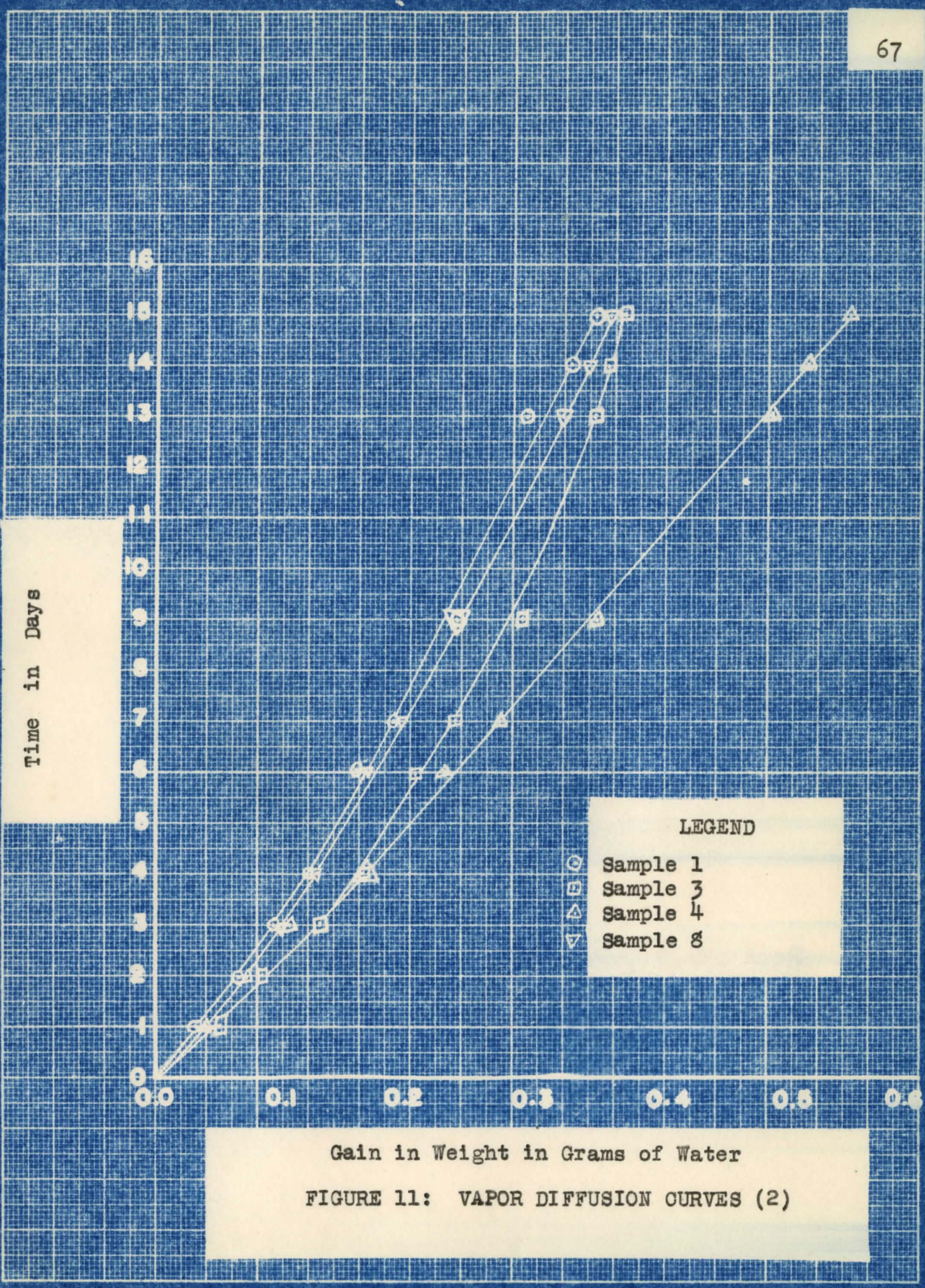




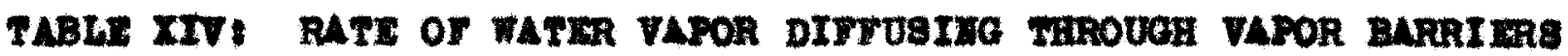

$$
\begin{aligned}
& \text { Banple Ho. } \\
& 1 . \\
& 2 . \\
& 3 . \\
& 4 . \\
& 5 . \\
& 6 . \\
& 7 . \\
& 6 .
\end{aligned}
$$

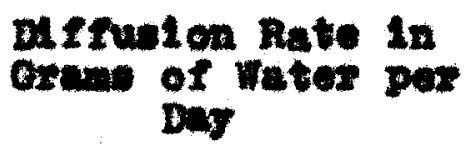

.0175

.0009

.0090

.0306

.0271

.0009

.0005

.0160

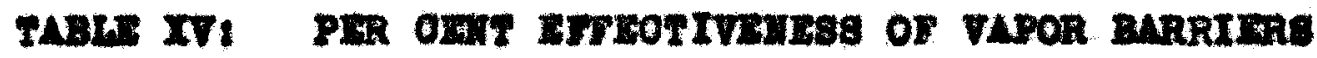

sample 50.

1.

2.

3.

4.

5.

6.

7.

8.
Ber Cont Erfeotivenew

$$
2.5
$$

95.0

50.0

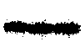

5.0

95.0

97.0

0.0 
testing these exaplee was to see whother aluntnum could be suocesefully bondod to plywood to serwe al a molsture barrier.

The following conoluelone wexe resohedt

1. The leafing propertios of aluminua ponder in an apheit rohtele provides an offective vaper berries.

2. Two ooats of a good vepor berrler are ouffiolent protootion.

3. Alundnum foll bonded to wood is the best rapor barrier.

4. The acourey of the wort is auffielent to reaomend

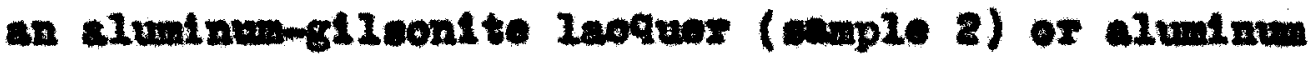
foll (aaples 6 and 7 ) a a rapor barriex. 
SUIUARYAIDOOXOLU IOU 
4 number of palnt formulations have been wade and tooted for weter vaper realetanee. Edse sealexe

Of the costinge teated, all chowed about oqual realetanos to water and water rapox. Of these the most desirable, as an adge conlex, was two coats of $40 \mathrm{pex}$ oent lesdod alno oxtde and $60 \mathrm{per}$ oont opur rarnite onamel. Rowevex, the uce of this onamel required a modiftoation in the plant produetion eobodule. At a seovad oholoe, a mixture of 33 per oest loaded sino oxide and 67 per oent Aree prinor palnt 10.156 wa coleoted. The only adrantage of wing this formalation was the allghtly

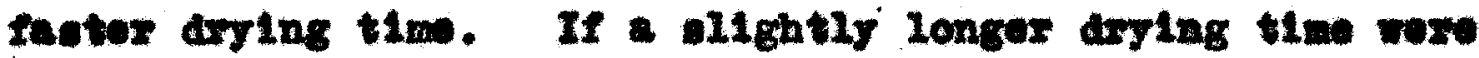
poestble, the flret coating would be far wore desirable. Teror Buriern:

Two barriexe were found to have alnost equal repor roeletanoe: (1) a glinonite eluminum lacquos: and (2) 0.001 Inoh thiokneas of aluminw foll. The firet barriex is ohoup and easlly applied from apray gun. Its offeotivenese with time Is not known but would be expected to dooresee oonsiderably as do all othor ouoh barriere.

The ecoend barrler is sonowhat more exponatre and mant be Inoorporated Into the plywod during manfaoture. Hewerox, ve the use of aluminim plyoed only in those seotlone of a bouge showing the greatest amount of wator rapex oondenention, thle prooden becones coonomlonlly feaclble. Honoe, if a house hat only alx windowe, only alx she ote of plypood in the ontire house would have the expenctre aluatnum as a vapex barriex. 
It wee reeomended that the aluminen foll be pleoed between the firet and weoond plye of the plyweod. It was augouted that the Iaeguex raper burrier be wed in the other wall ceotlone requiring lose protootion. 
II. OOREVOIDIILLER FOR

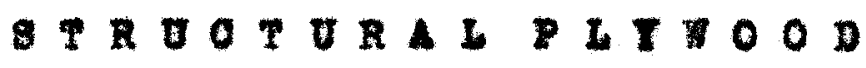

I 2 R 0 D 
The lden of a cors rold 1112 ex ortglneted beeause of Liporfeot glutus of the center ply in a threomply plyreed

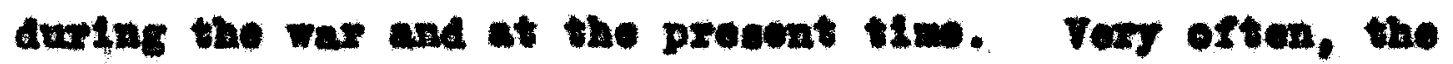
centex ply conelated of two pleces whose odges bed not been trimed to form a tht jolnt reoulting in wde oreviees oulled cox rolde. Gut to ofton those rolde extonded longltudinal2y trom one edge to the oppostte edge of the panol, Ienving an

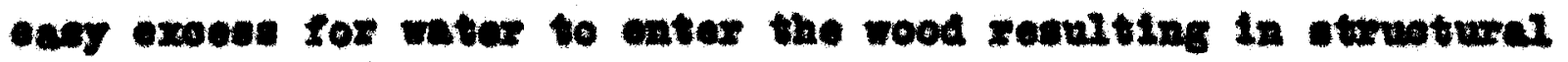

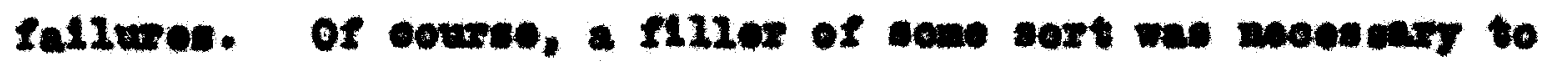
piug thene holes.

The t112er we to be spplied of the rood wored horisentally

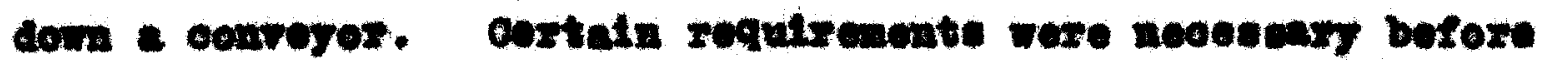
a flire could be owposaful. The thiler

1. wut be Inoous mough not to leak out of the rolde betore hardontas.

2. muet hardon repiety at $120^{\circ}$.

3. met have a loas pot 146

4. wavt be palnteble

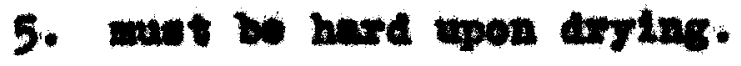

In this cooticn of the roport the zeoulte of an Imvesti-

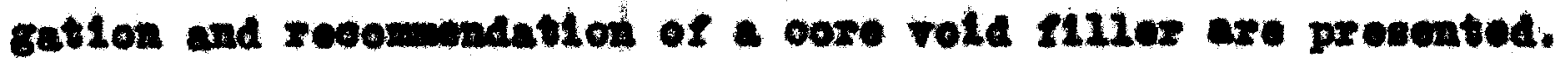

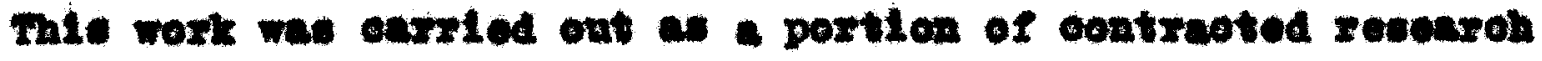
of the Dntrexity of Iouloville Inotitute of Induotrial Rocoaron. 
EI 20R104 
The upeolfto problem of couling holes in wood to corexed almost ontlrely in the patent 11 terature oniy. In 1928 (39) - patent was Isemed fox a wood subst1tute condsting of 11m, plevter of paris, ooment, acnd, and watex. In the cane rear brene and Andreme (40) formulated ocmpound oonelating of andust or ooxk dunt, 50 to 70 parter rante rope halx ox enimal hals, 10 to 20 partel forrou alfate, 1 to 2 partet oelolum oarbonate, 10 to 15 parts! and othor mleollewoous

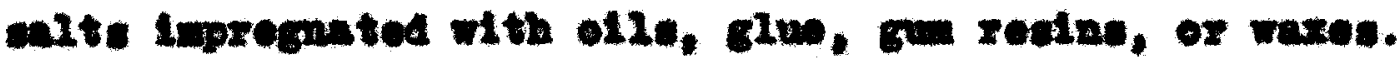

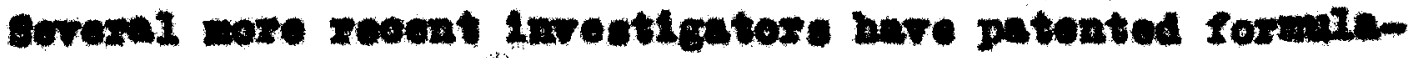

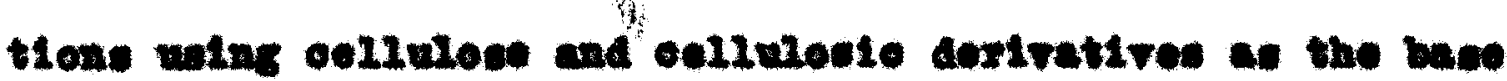

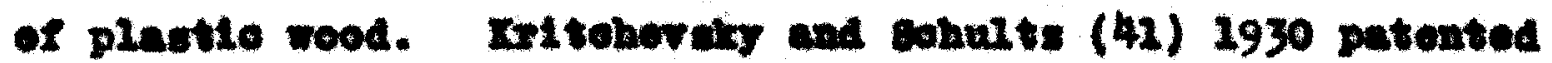
a formalatten that could be epplted without prosoure and worked by wand. Whis constïted of oellulota, cooton, bencol, cthonol, and rood nowe. A dinlar oompoumd was disoovered in 1937

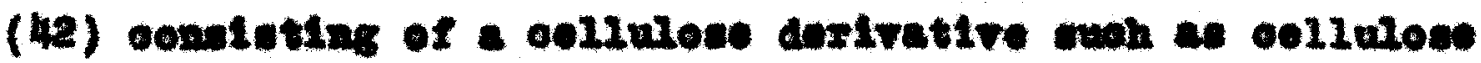
sootate in sootone and wood hour. Snothor elnilur patent,

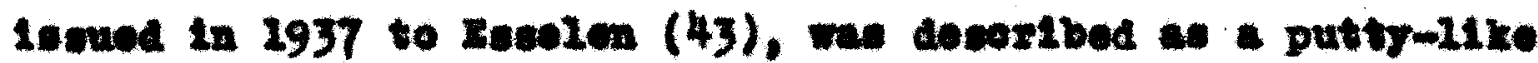
cospound that would haran on expocrure to aly to the haranese and rictuts of rood. 


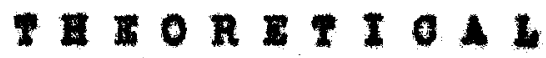


The hiotorteal neotion Indleaten that paet coxe vold

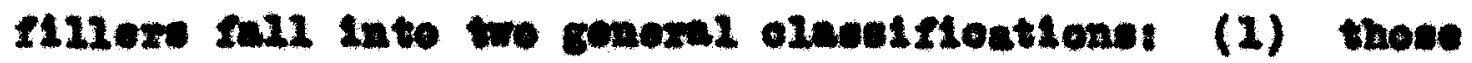

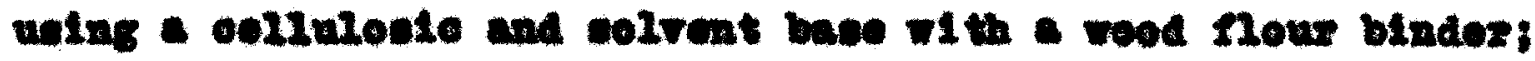

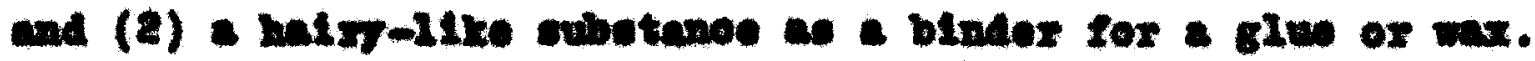
The inveotigation proconted in this roport wa linl tod to the

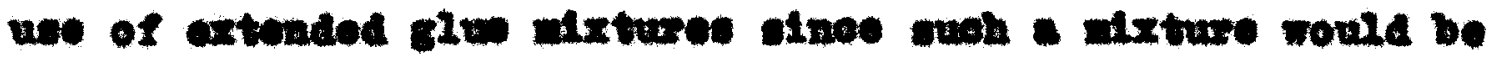

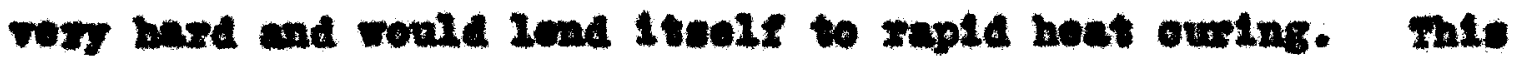

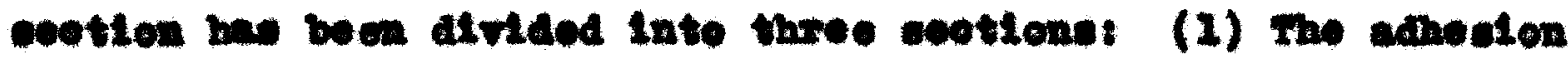

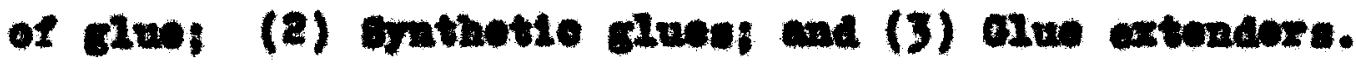
the condea of riv.

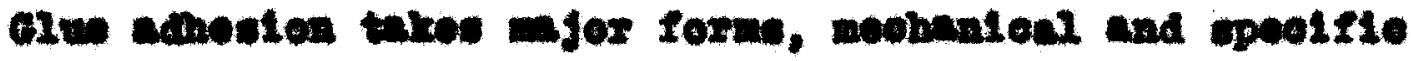
(44). mon glw is appiled to wood, it gatne woeses to the

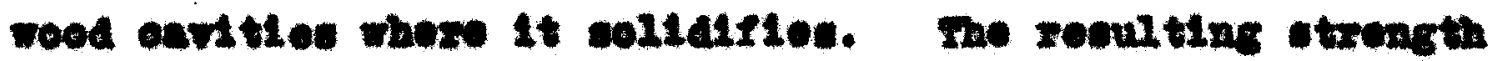

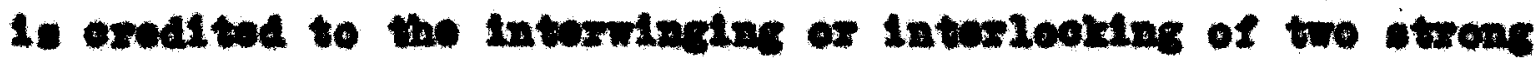

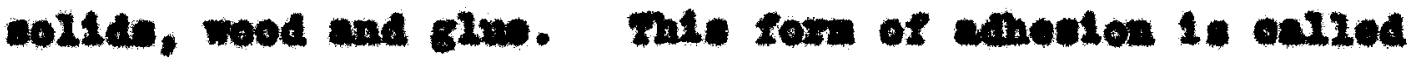
mepratien.

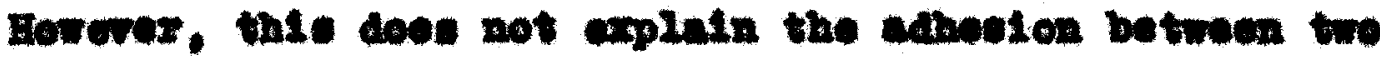

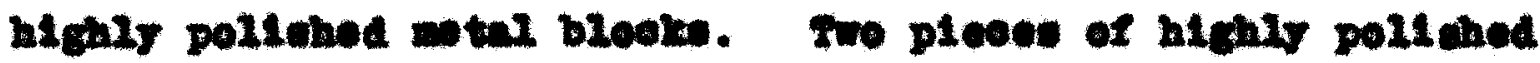

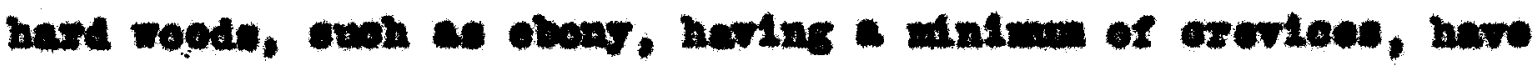

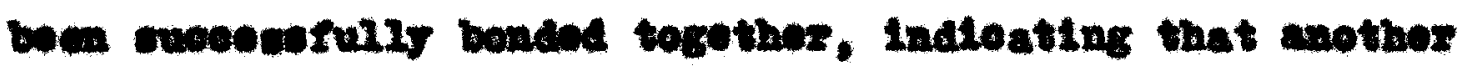

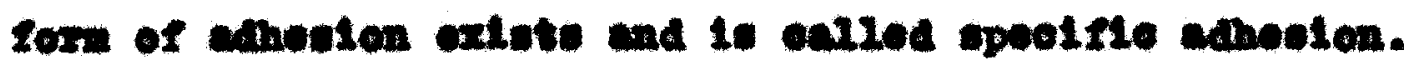

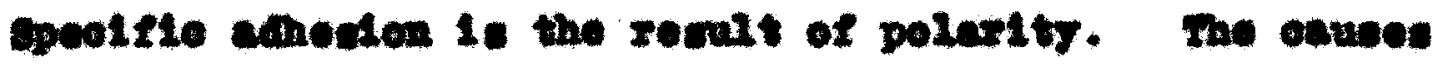
of polexty hare been alsouned alewhore in thle report. It

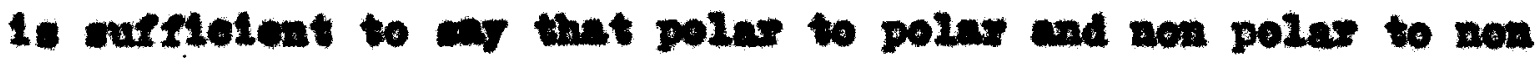

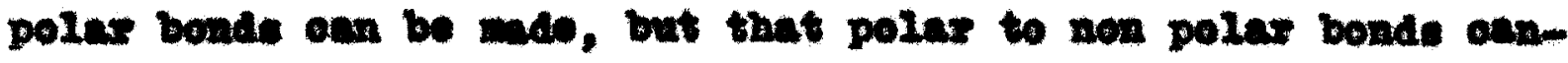
not be made. Woed is poles, and arithotle glupe axe quite polar. 
Exthetie niven

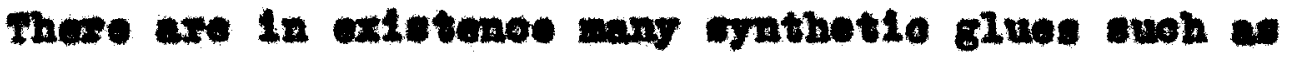
woa formaldohyde, phenol forweldomyde, resorelnol tornaldehydes, Dolemine lormaldohydos, fingl resin and corifio reoln

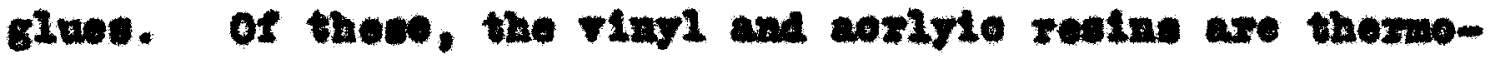
platilo while the othere are thermosetting.

The thowesetting formaldohrdes are partially polyeortzod oempormde of a reste and a formidohres. After applieation

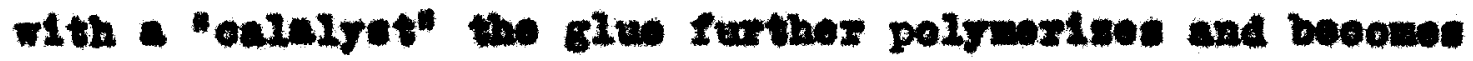
thorescetting. The eppliestion of heat and presenre spoeds up the ohomioal resotion.

\section{Extrader.}

Extendare (45) we cdaltional Ingrodlate inoorporated in

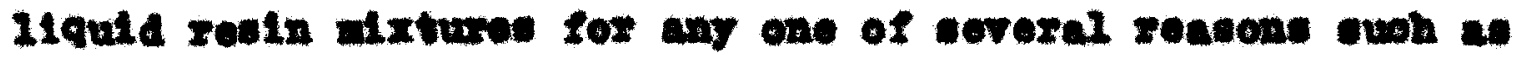

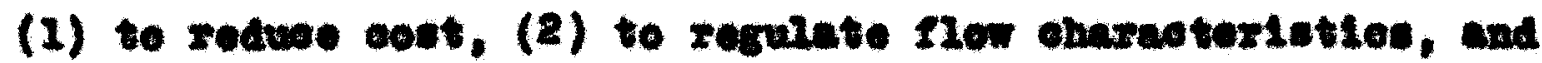
(3) to rodupe the ouning tomperature. Whost and $x$ e are often added to uree glwos to redwee the oost of the glue, Bried blood, whe added to phenolte glues, w11 rogulate the how oheracteristles and redve the ouring tomporature of the rewulting atxture. 


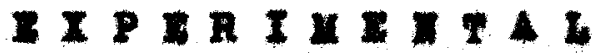


In ordox to oraluate the rillere veted, ourtaln stundarde woro arbitrarily formileted.

1. No onrivirage

2. Mardes than wood

3. Fir pisogesty

4. Gulor arins

5. Palntabre when wos

6. Woather roelatraces

7. Io biondins

6. Reseonebio pot 117 .

\section{Eneretental procodurs.}

Folos with $3 / 6$ inch bore and one inm doep were out in blook of wood. The 1112ex, betns teuted, were foreed Into the holes and allowed to ect. After 24 hoture thor wexe exnm-

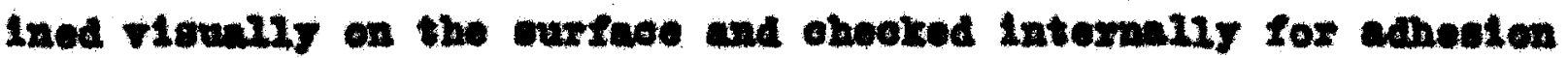
by outting the blecke of wood through the ante of the holes.

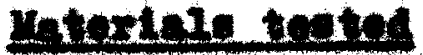

Twe trpen of glues wore oboesn for inveltigatiost (1)

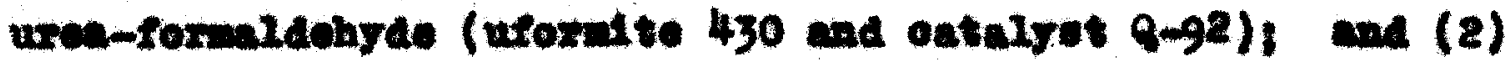

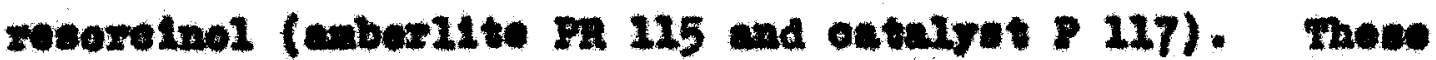

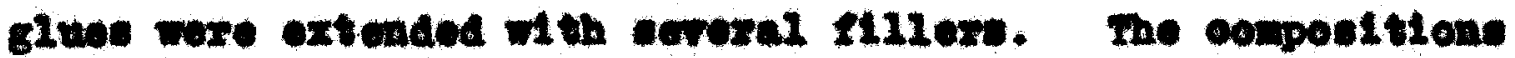
of the eore veld enclere are lieted in rable $\mathrm{xV}$. Rentit

The xeoulte of the teote are Ilated in rable xyI. Fable XTt has been subdrided inte three sroups. Group A we teated

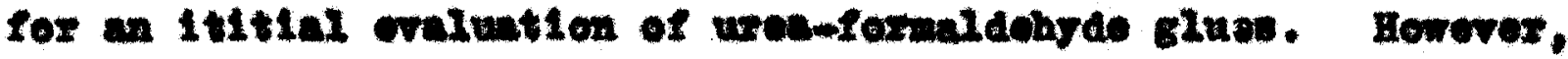

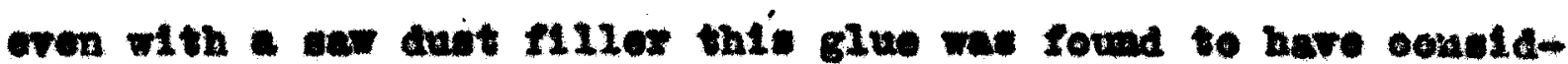

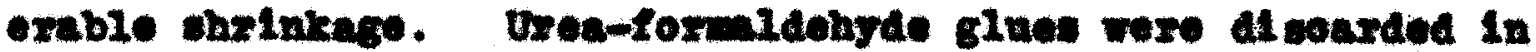

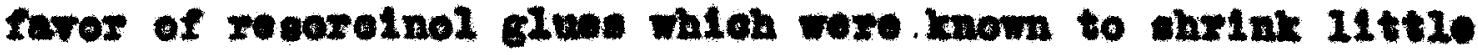
upon drying. 


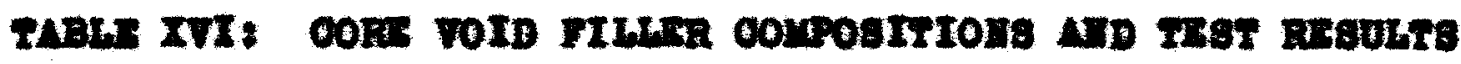

\begin{tabular}{|c|c|c|c|c|c|c|c|c|}
\hline mo. & Coupostrio & & 0o20x & Earenese: & $\begin{array}{l}\text { Intexinal } \\
\text { Daximeage }\end{array}$ & $\begin{array}{l}\text { Extomax } \\
\text { Enximitere }\end{array}$ & somegten & Oenment \\
\hline 2 & $100 \&$ ufomite & & wato & cood & cosoese & excoes: & poox & poox \\
\hline 2 & $70 \&$ meond to & -30 ; antuat & winto & coed & modorate & none & good & mar \\
\hline $\mathbf{1 b}$ & 60 , abenitse & -20 \& pondenod & purple & modte & nowe & now & $\operatorname{sen} x$ & $\mathbf{t a t}$ \\
\hline 20 & $68 \times 1$ & & porple & beod & moderate & none & $\operatorname{mix}$ & $\sec x$ \\
\hline 33 & $60 \%$ & & beome & bood & modomte & moderate & fats & $20 t$ \\
\hline 40 & $64=$ & -20 & purplo & $b x+420$ & modoxnte & moderete & atr & rats \\
\hline 5 & $60 \%=$ & -4 & beons & betitine & nodorete & modexate & $\operatorname{tat} x$ & set: \\
\hline 6 & $10 \%$ & -60. & bown & betse & moderete & moderate & $\tan x$ & 20 \\
\hline 7 & $20 \leqslant$ & . & basem & sood & nome & mocerate & fall & ents \\
\hline 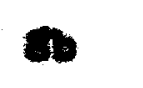 & $80 \%=$ & -20 & $y=p a l e$ & soed & tem & moderate & eod & oed \\
\hline 90 & $40 \%$ & $-60 \%$ & purple & sood & not & nome & sead & \\
\hline 10 & 70 \& anberiste & $-30 \%$ & purple & bettelo & none & none & 000 & a \\
\hline 20 & 60 \& antexilt & $-40 \%$ & 210 & good & exoens & exeese & oor & \\
\hline 30 & $55 \%$ arberitto & -458 & brom & coed & woderete & moderate & poor & \\
\hline$\infty$ & $50 ;$ antaristo & -409 & $\max$ & $\operatorname{cost}$ & nene & none & $100 \%$ & \\
\hline 50 & $45 \&$ anborilto & $-55 \& a 11$ & be & sort & none & none & poor & \\
\hline
\end{tabular}




\section{PDI Xr. Goatinued}

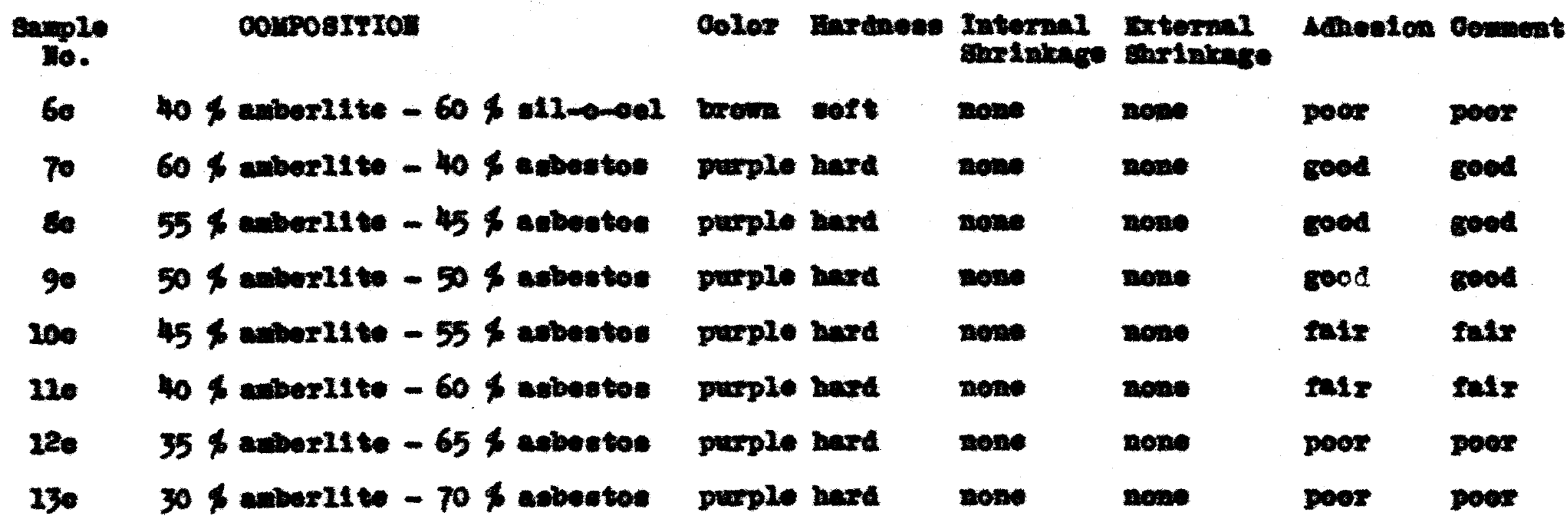




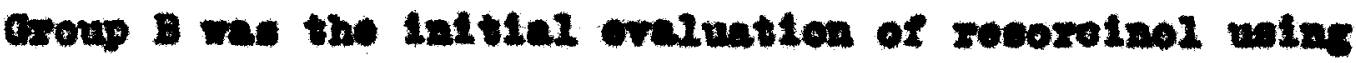
varlowe cxtondere, pondored winut voed flow, kelln olyg.

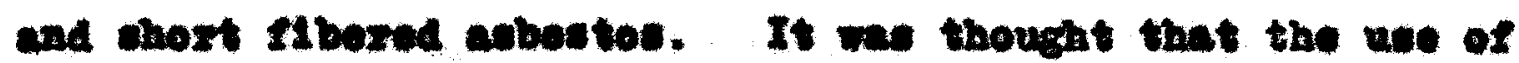

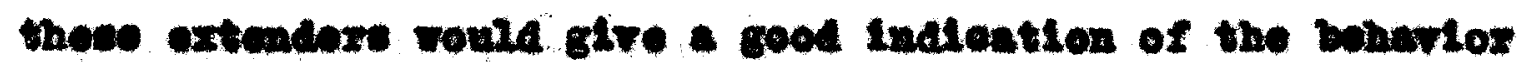

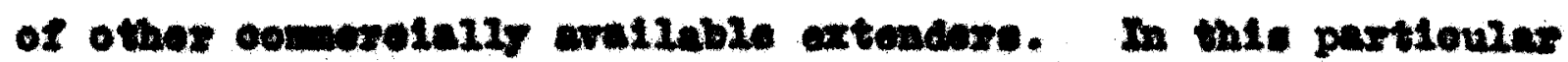

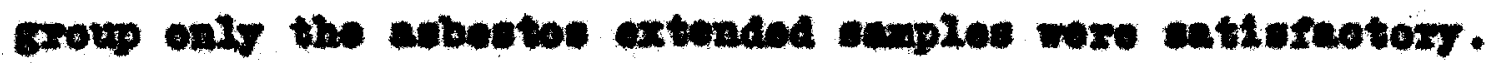

Anvotes is a Ruft mtorial. In group o crbetos and

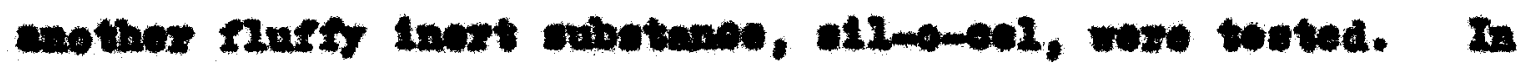

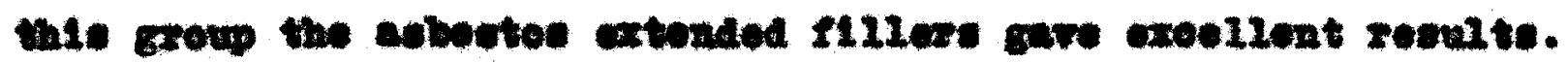
Derenter

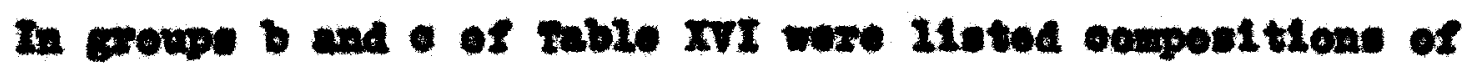

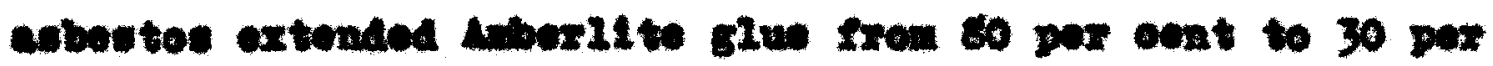

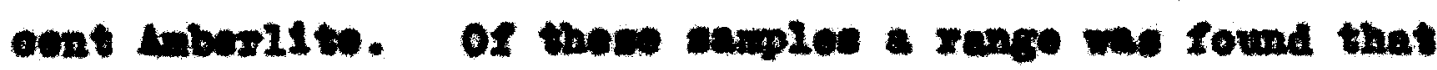

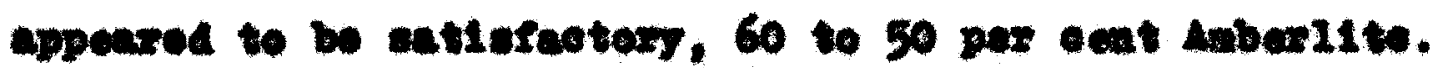

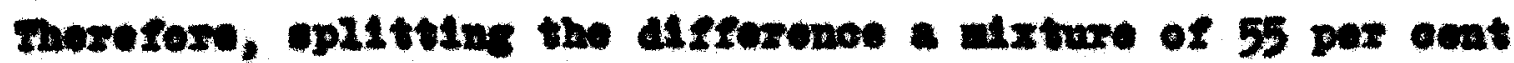

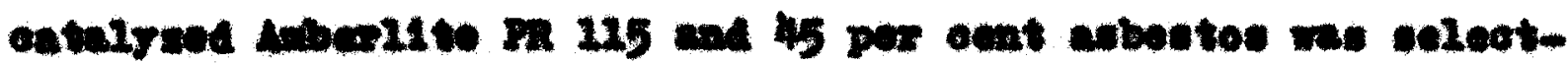

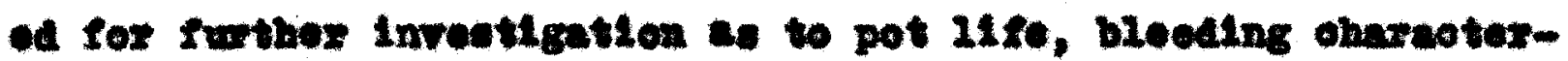
Intloe, and time of owre.

The proportles of the colcoted alxture wore as followst

2. Conelierebtr marder then wood

2. Dries to cont hardnees in 22 minutes et $120^{\circ} \mathrm{y}$

3. Patntable wile wot

4. Panple in oolos

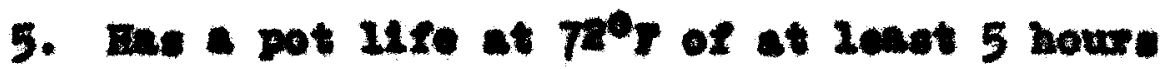

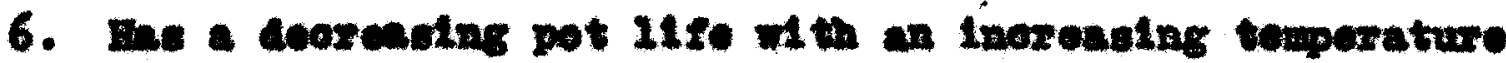

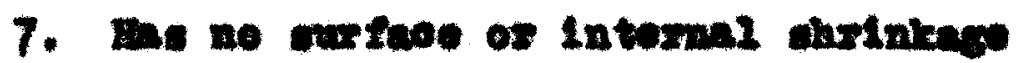


8. W111 not bleed whon beated at $135^{\circ} \mathrm{y}$ for two daye or When coaked in water for ho howe

9. Forme atrong boal with wood

10. Oamot be Iightened in color by plgnont addition

11. Wo detrimontul offoste from troestng at minus $9^{\circ} 0$ for 45 hours

12. Oan be applied with a putto latio

13. stuine oan be romored bafore hareming with a dap eloth

14. De the conatetenoy of putty 


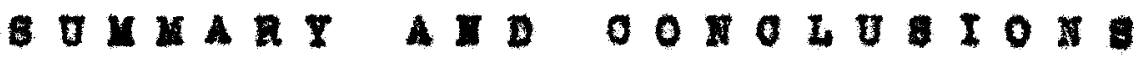




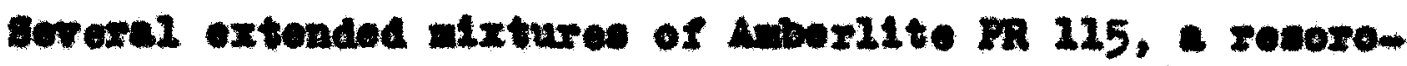
Inol glue, were extended as, oore vold flilers. Of these, a eample of 55 per cont oatwirsed Aberilte and 45 por cont ohort

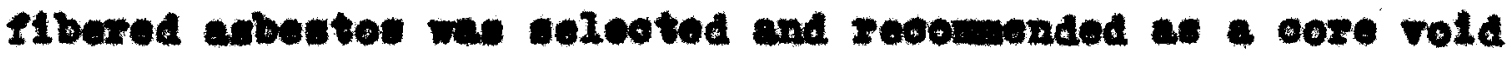
f1110x.

This axtare 1 ende 2 teelf quite well to mane produotion mothode in that it ean be epplled from a preasure $6 \mathrm{~m}$, or 1 t way be applied by hend.

Io explanstlen oould be chiren to sopount for the fallure of the rood flow mixtures. Wood how has been used swoosesfully for ecreral rears as an extender. However, it wy be poselble that the large veluw per unt ourfece ares uecd in thit wexk required the vee of an inont oxtender that would plecteise the mixture. Abbotos would have served this purpose beouse of 1te Alafy nature. Howorex, Al2-0-0el, an

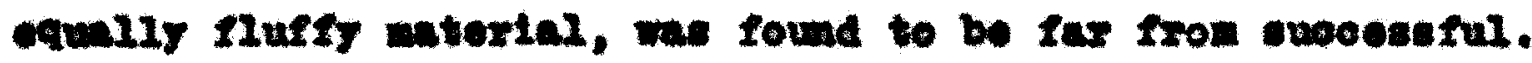


ZITER TER OITED 


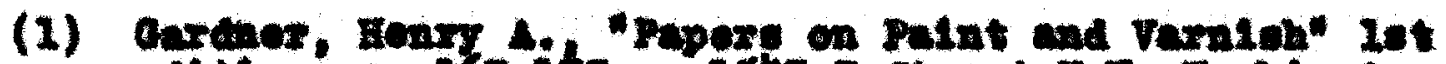

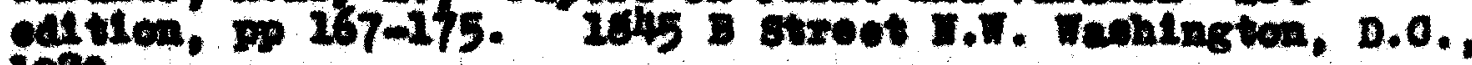
1920

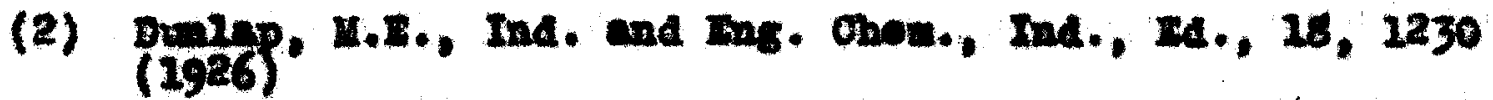

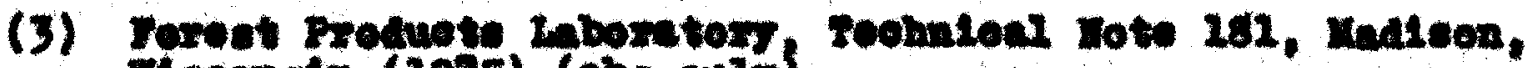
Whoconstn (1925) (abs.only)

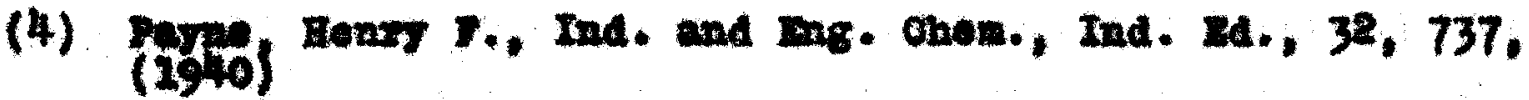

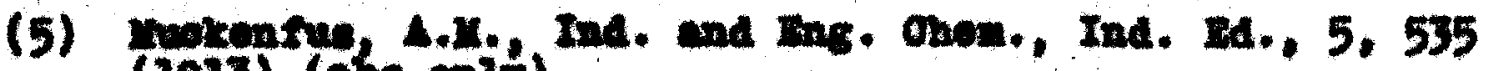
(1913) (abs.onit)

(6) Browne, D.h., Ind. and Bng. Ohen., Ind. 24., 25, 638 (1933)

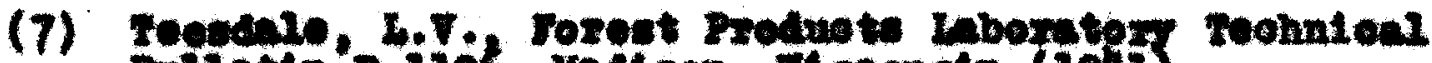

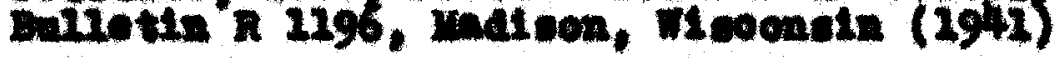

(6) Tocodure, L.7., Bottes Homor and Gardene, 120 (1947)

(9) Wra, R.I. and Jen Yoxet, A.R., Ind, and Ing. Onow., Ind. Ba., 25, ghe (1933)

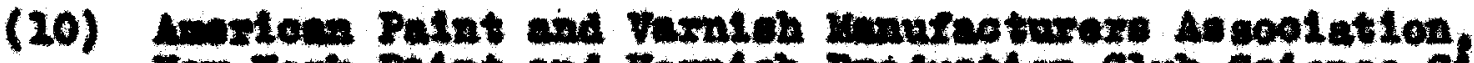

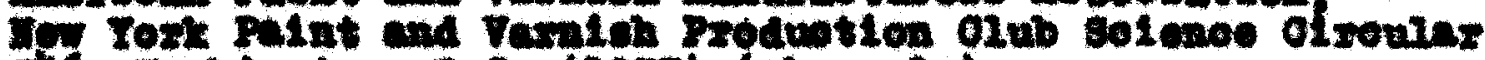
5\%6, Whonington, 0.0. (1937) (tw.only)

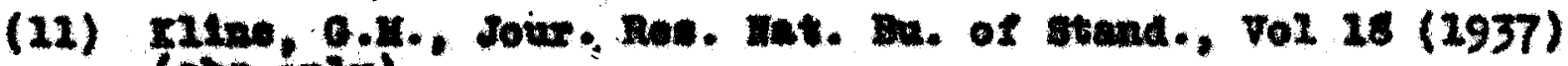
(aventon) :

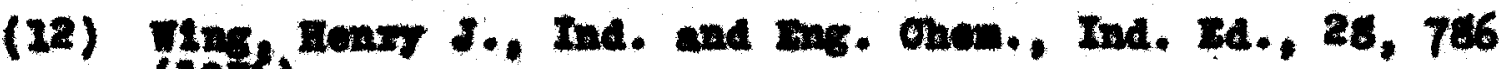
(1936)

(13) ILna, R.H., Jow. Soo, Ghew. Ind., 55, 229 (1936)

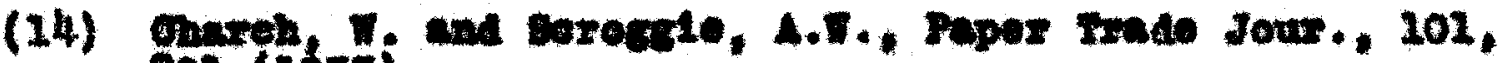
201 (1935)

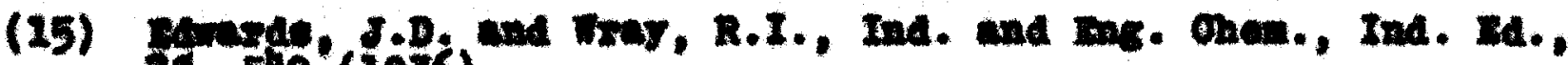
26. $579(19 \times 6)$

(26) Cown, 0.4. and H110x, I.J., Ind, and Jug. Ohon., And. Ba., 15. 737. (2937)

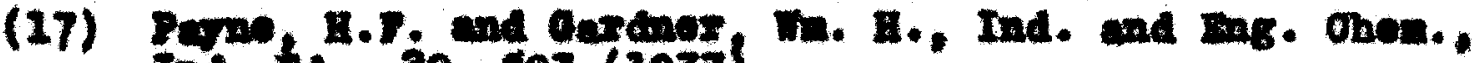
Ind. 2a., 29. $893(1937)$

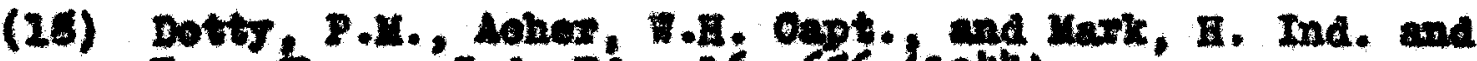
Ins. bnom. Ind. Id. 16, 686 (1944) 
(19) Pane, R.F., "Proteottre and Deocuttre Oonsinge" Ist

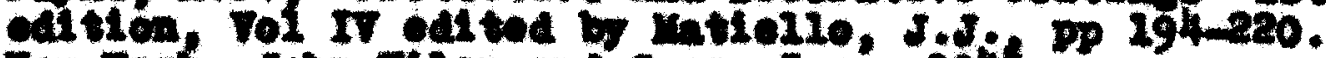

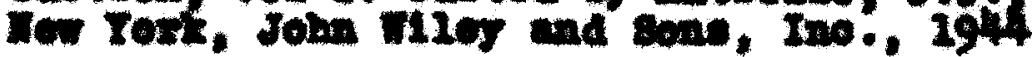

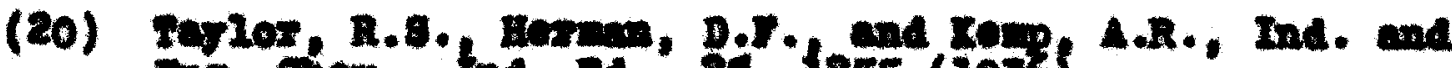

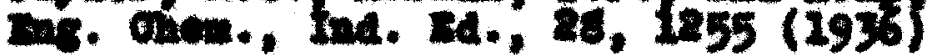

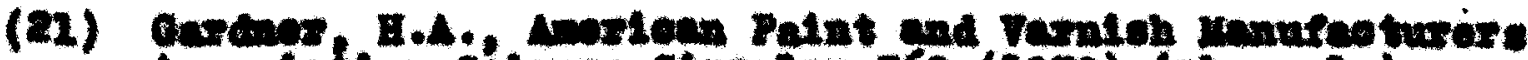

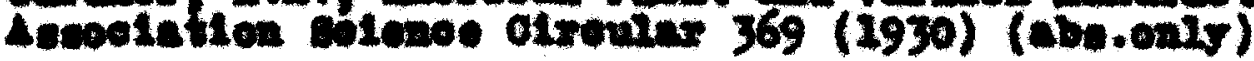

(22) Contnoz, R.A.. "outhines of Bloohongty" and cattion, Now Ioxt, Jom wiles and sons, Ino. 193: (abo.onty)

(23) Bux, g.x, end gtem, 4.J., Ind. and mas. Onom., Aner. 2a. $23.655(2941)$

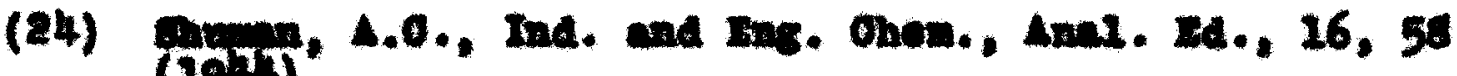
(2974)

(25) Tien, Brry Bonid, "Tood roohnolop" and. odition,

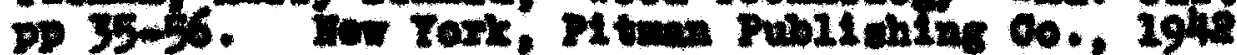

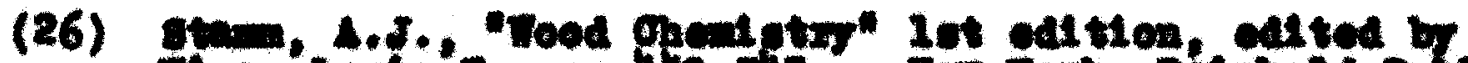

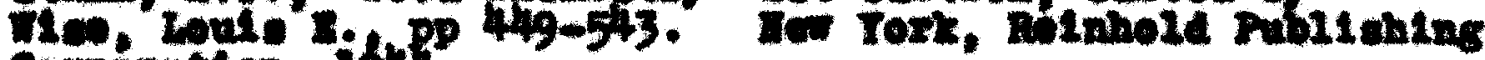
oerporation, ight

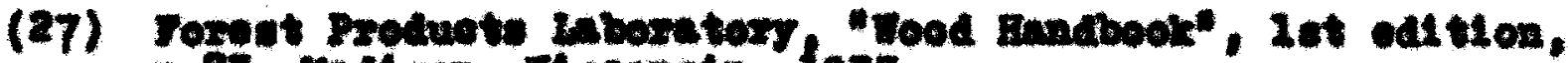

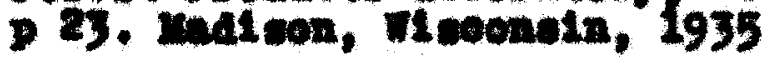

(28) IbLa., De athas

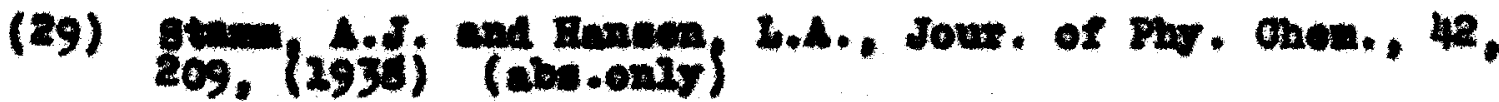

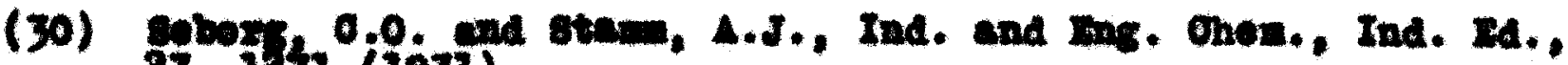
23. 242 (1931)

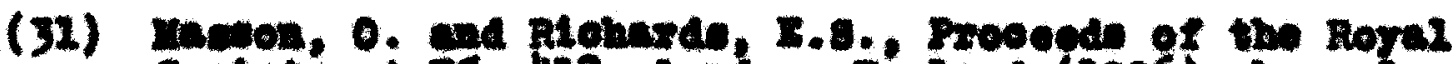

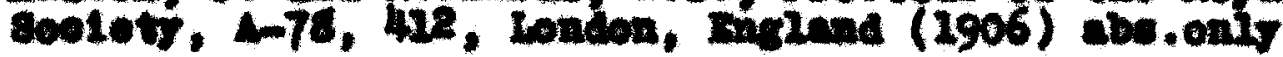

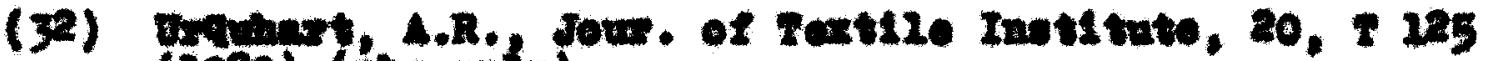
(1929) (abe.cats)

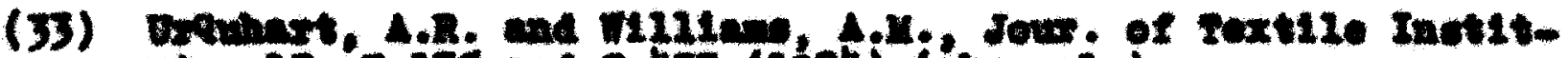

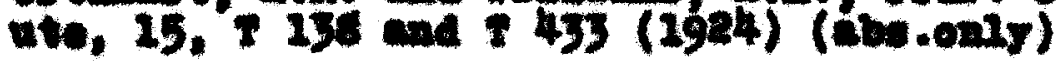

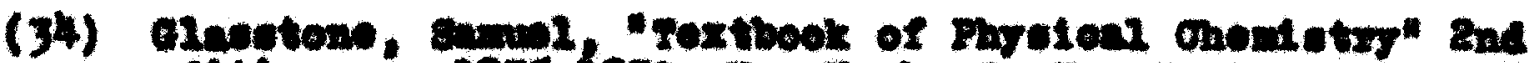

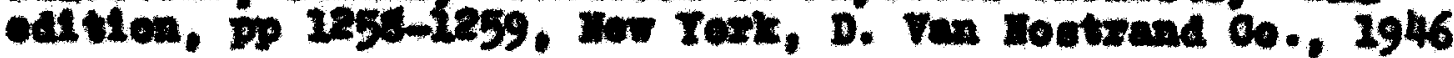

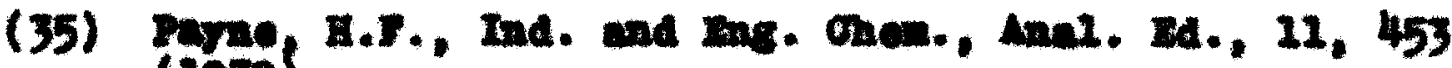
(3939) 


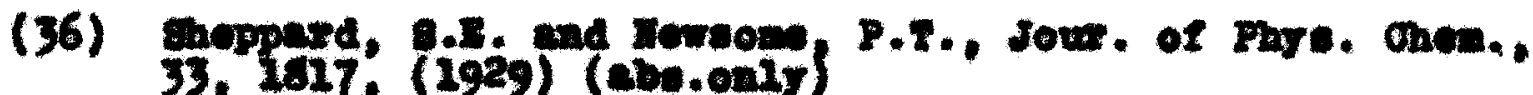

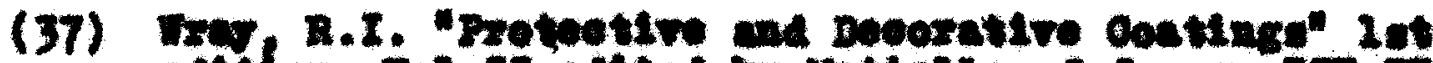

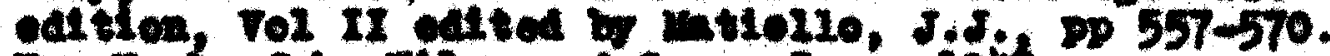
Iow Tork, Joln WLIer and Bone, Ino:, 194.

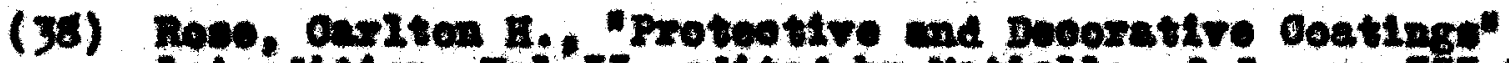

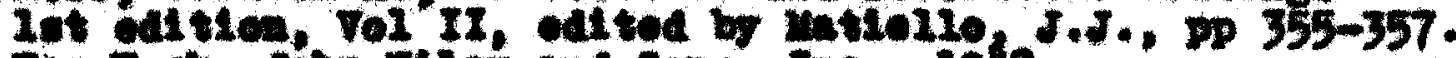

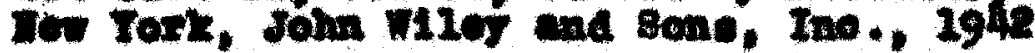

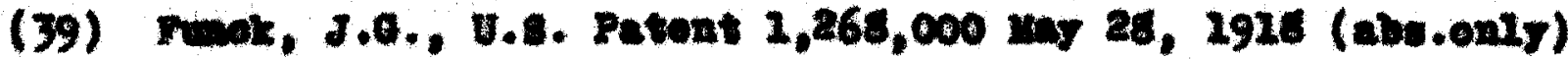

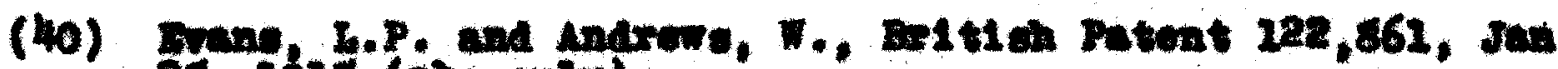
28. 2926 (abs.onty)

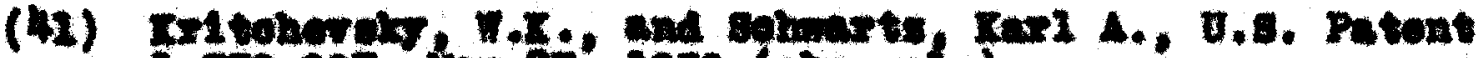
$1,759,907$. in $27 ; 1930$ (abe.enty)

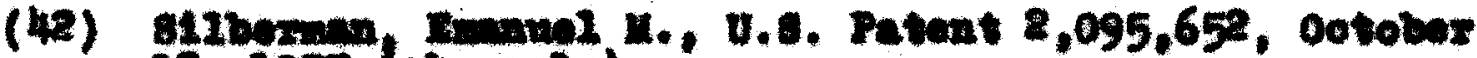
12. 1937 (abe.0uly)

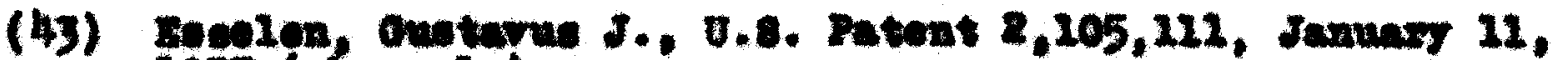
1937 (56e.onity)

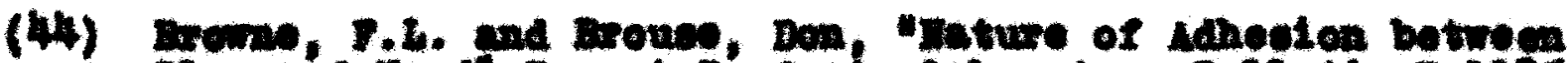

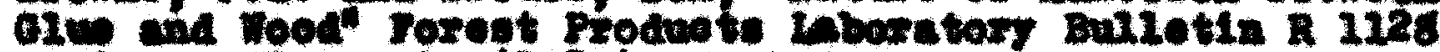
wedron. Firoonin (1929)

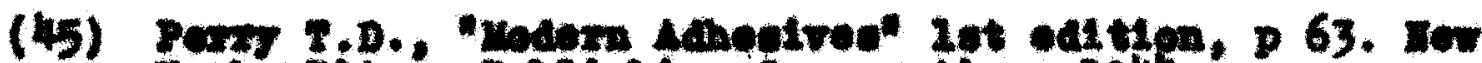

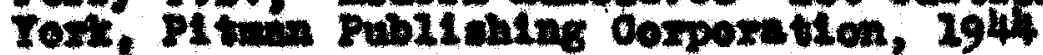




\section{Aoknowledenent}

Thts zocearoh was mode poselble

through a tollowntp grant from

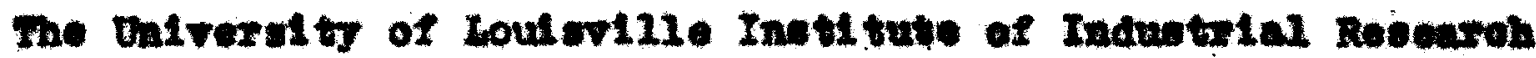

a a portion of contraoted rewearoh with

Crmilean Homes, Inoorporated 
A P I DXX 


\section{Saxple Oalowitions}

I nater Imoraton rocting

a. Weight of wetor gatuod by enmples

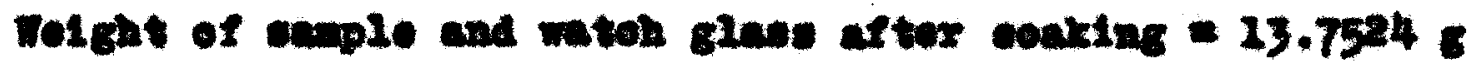

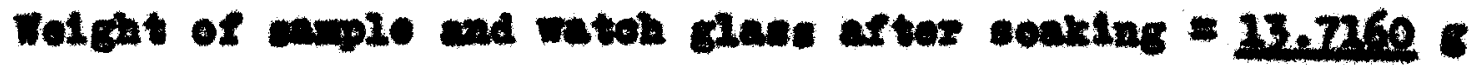

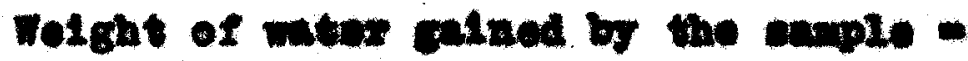
$.0094 \mathrm{C}$

b. Lar Iongth converted to one foot

2 adre zensth o

$2 \times$ age wath $=$

rase pontmote: $25.5^{4}$ on

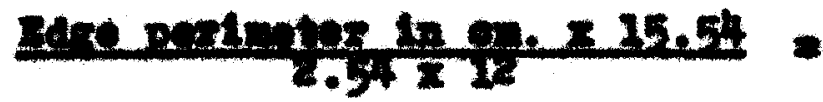

race porimater in foet .52014.

- Nolght of wator gatnod in gran pez foot of avorago Iongta

Wotght of water gained .00948 nase porimotes = .51021 Woight of water gatned in gran per $100 t=\frac{.0094}{.510}=.018$

a. Por Oens effectivenene

Wolght of water gulnod per toot of arozage odge longth of a blank enaple = 2.12 wolent of wates gatnod poz loot of arazage olse length of a ooted maple .018 Pox cent efreativenose $-\frac{(2.2)-.015)}{2.11}=100=99.1$ 


\section{Toper Earrios Iralention}

Q. Fater aftuned arter three dare teatlng

Dolgt of exple and wolfaing bottle eftes throe ance teetting $=$

Waight of anple and wetghing bottle befoxe teoting

Vator clefued arter three dors teoting

b. Deftuden seve

mow a plet of the in dare vexone water diffuned

In gram the seotpreal of the alope of the and pertlon of the ourre we taken in grame pex ons = .0005

- Por ount elroetivonede

Diftudien rate of a blank sample .02000 Difruaton rate of en untreated eaple = .0005 Por oent exreattronens $=\frac{(.0909-.0055) 100}{.04}=97.5$ 


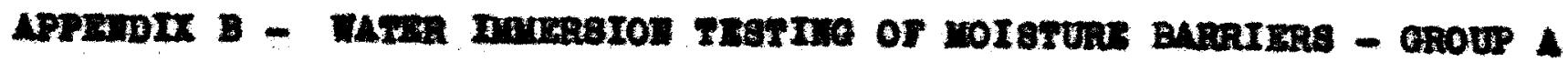

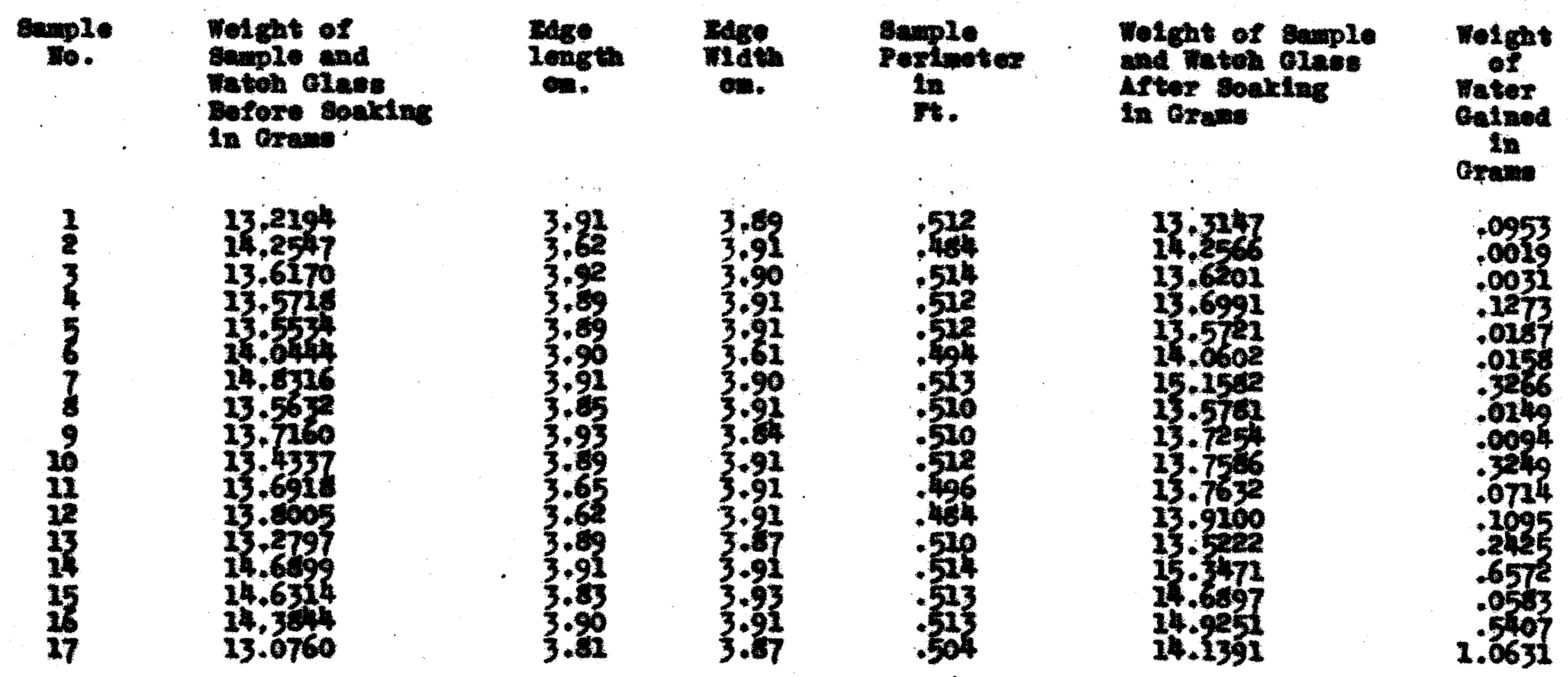




$$
\text { APPEDDX B - COMTHUE }
$$

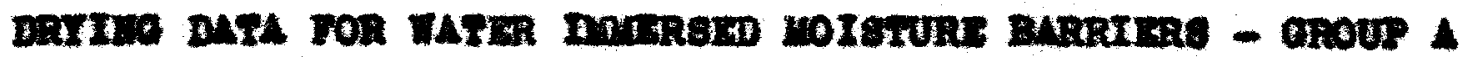

Wolght of saples and Iatoh elaen in Crans

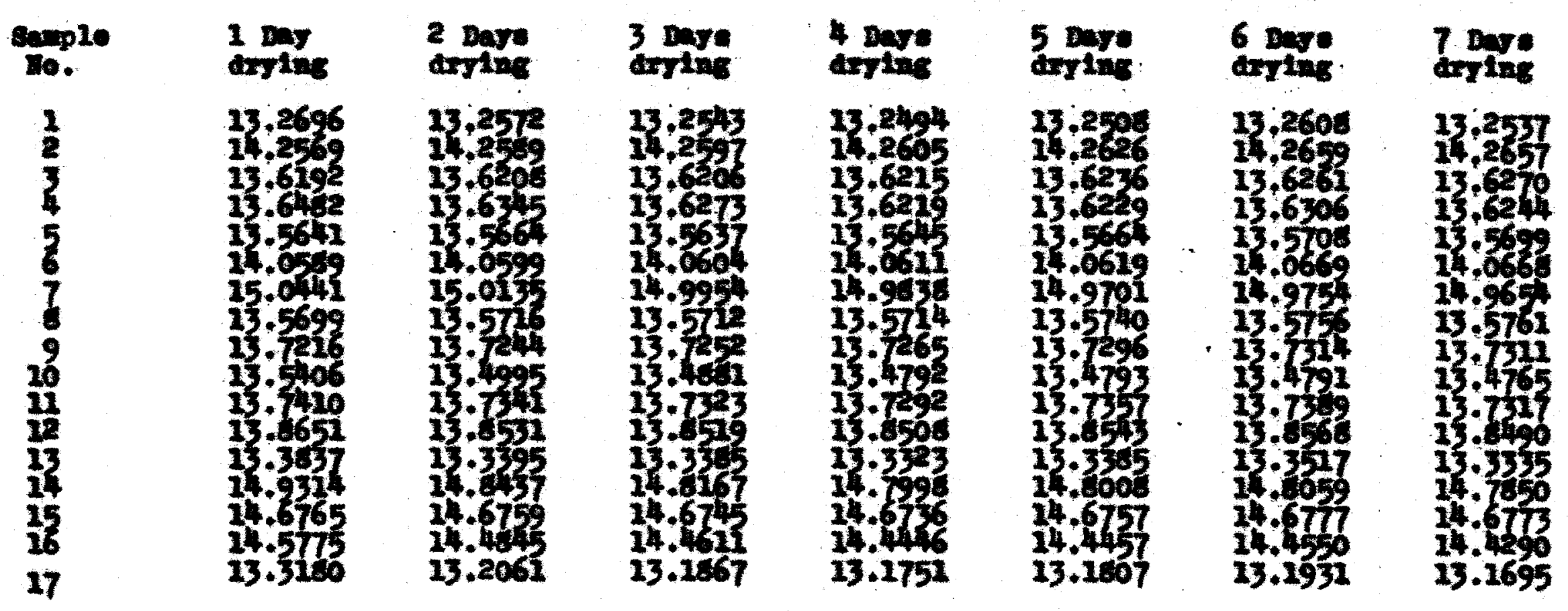


APREDI B - CoMr TEU

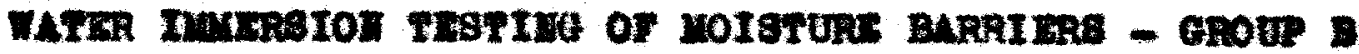

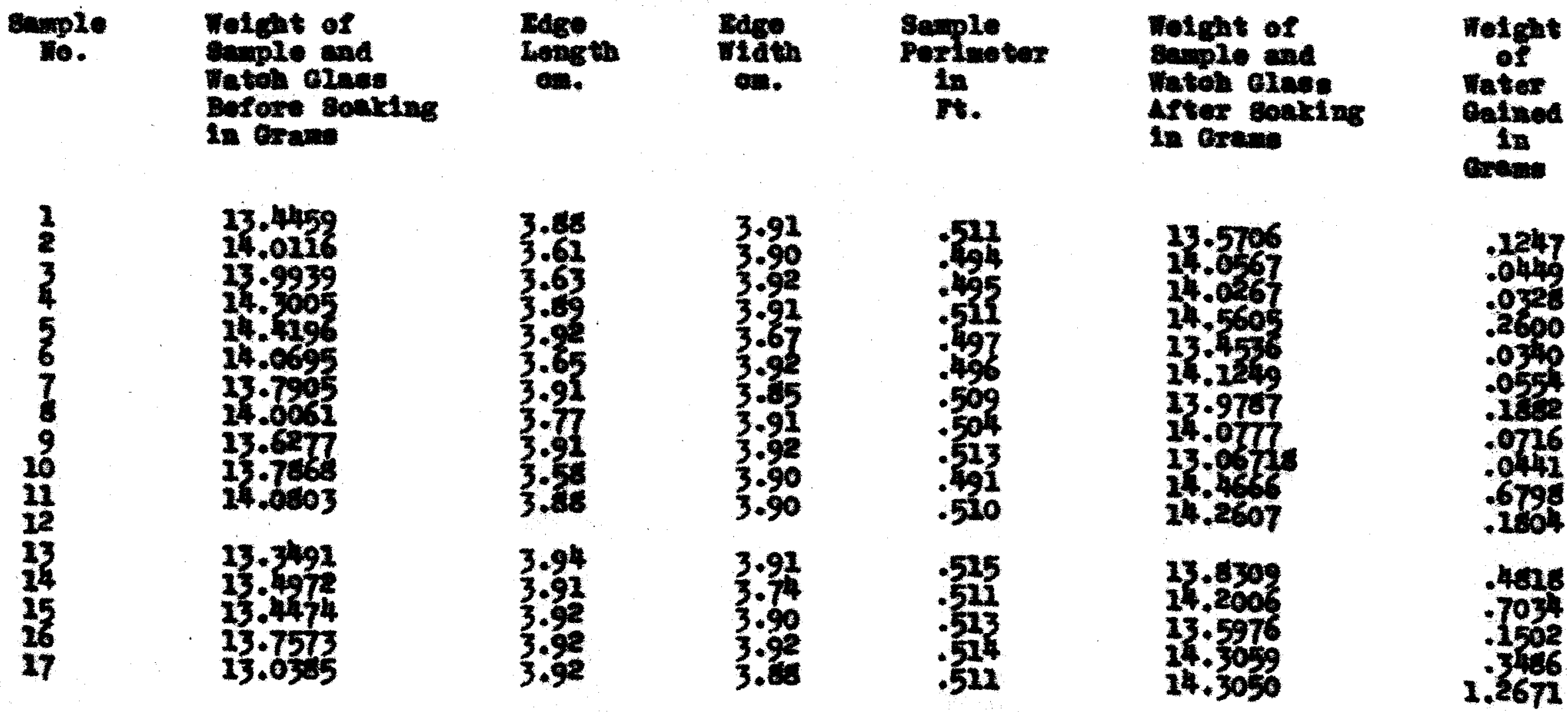


APPEIDTX - - OimRULD

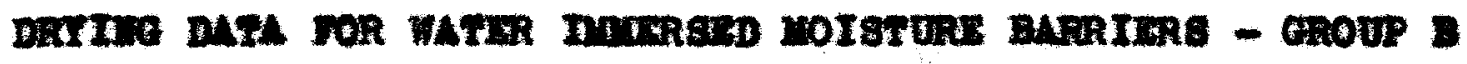

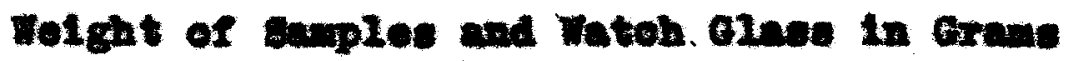

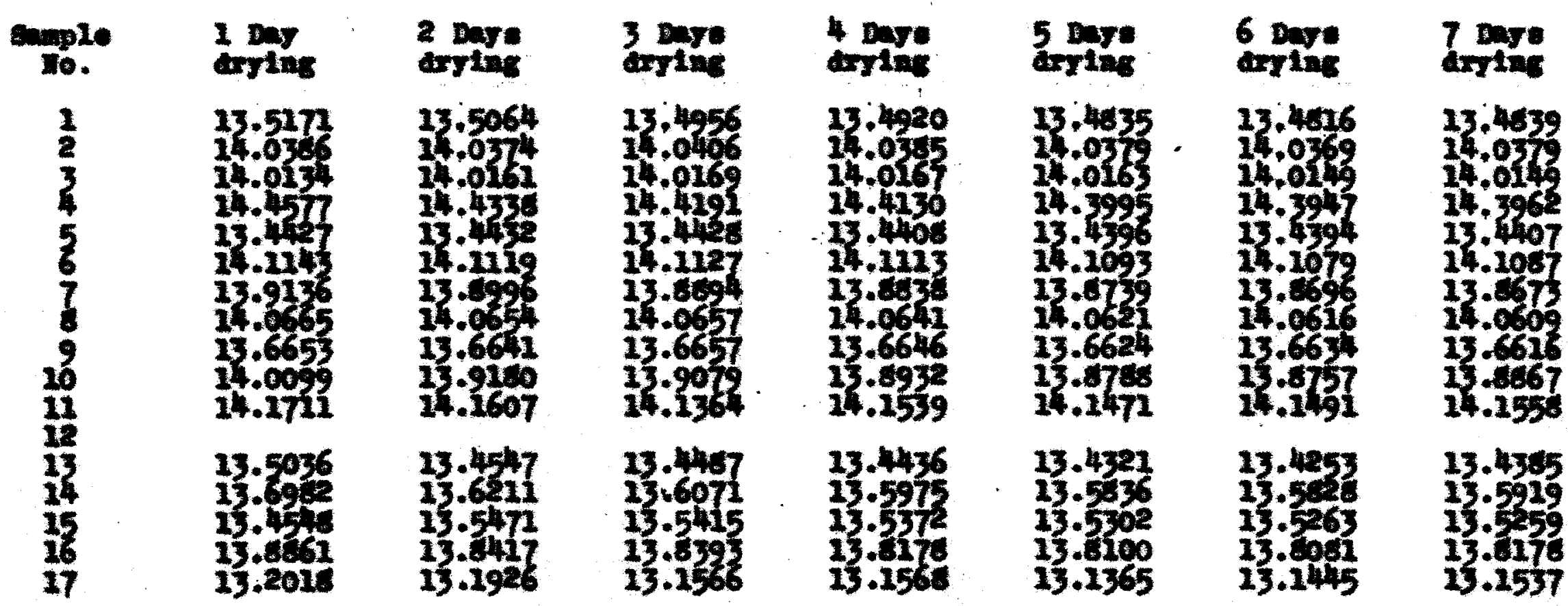


APPEDIX B - COXTTUED

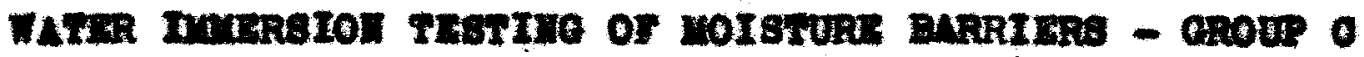

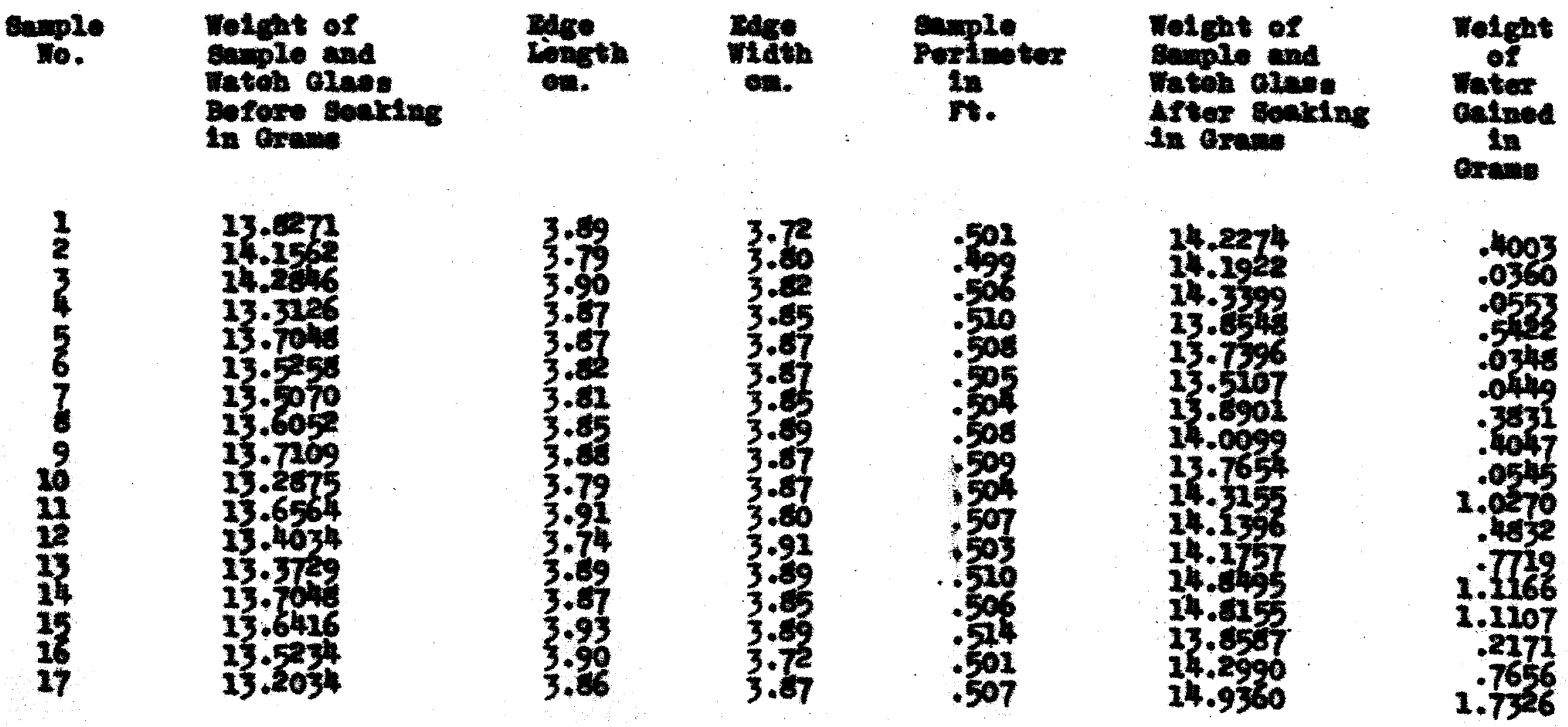


APPADEX B - OOTrImU:B

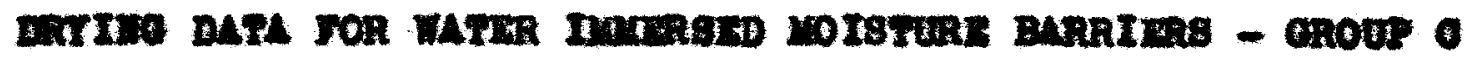

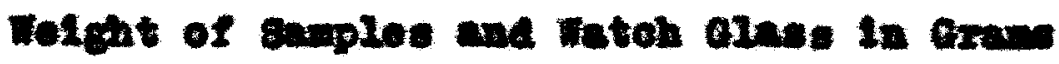

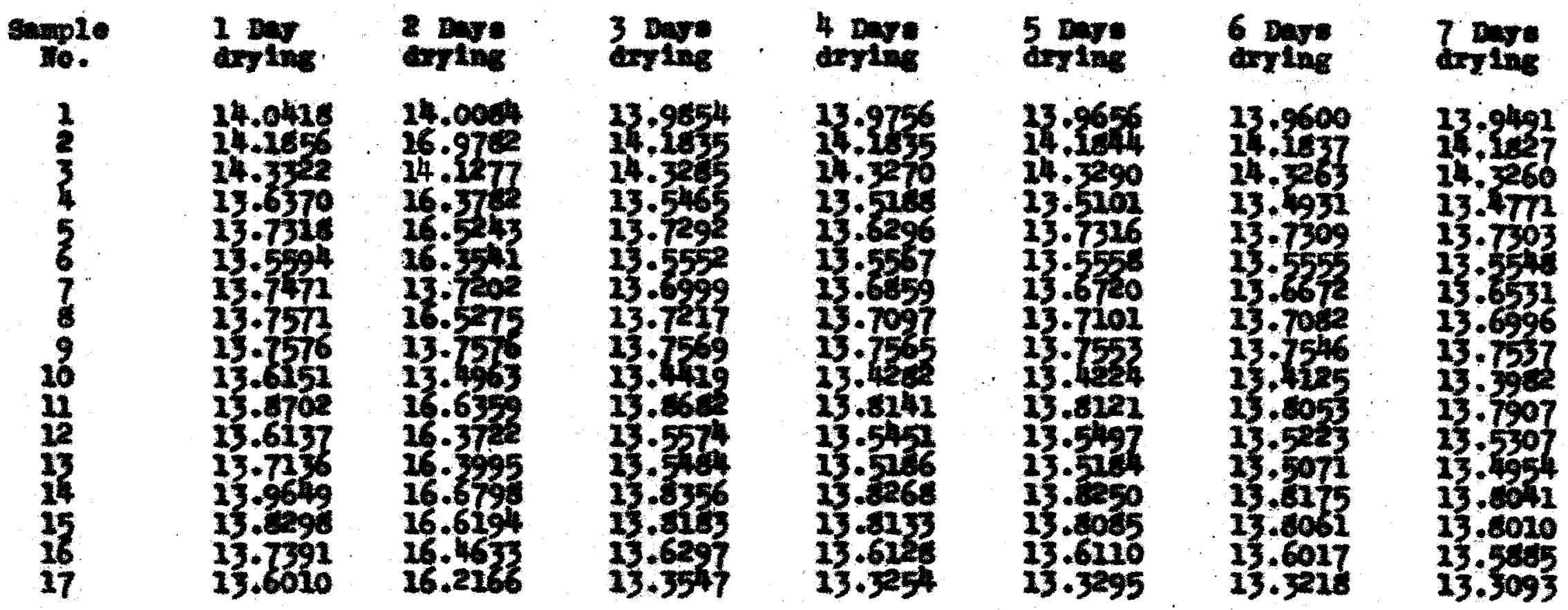


APPEIDI B - DOFT IUETE

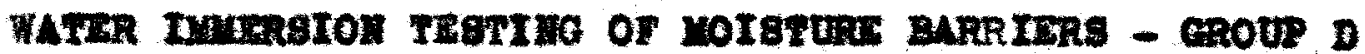

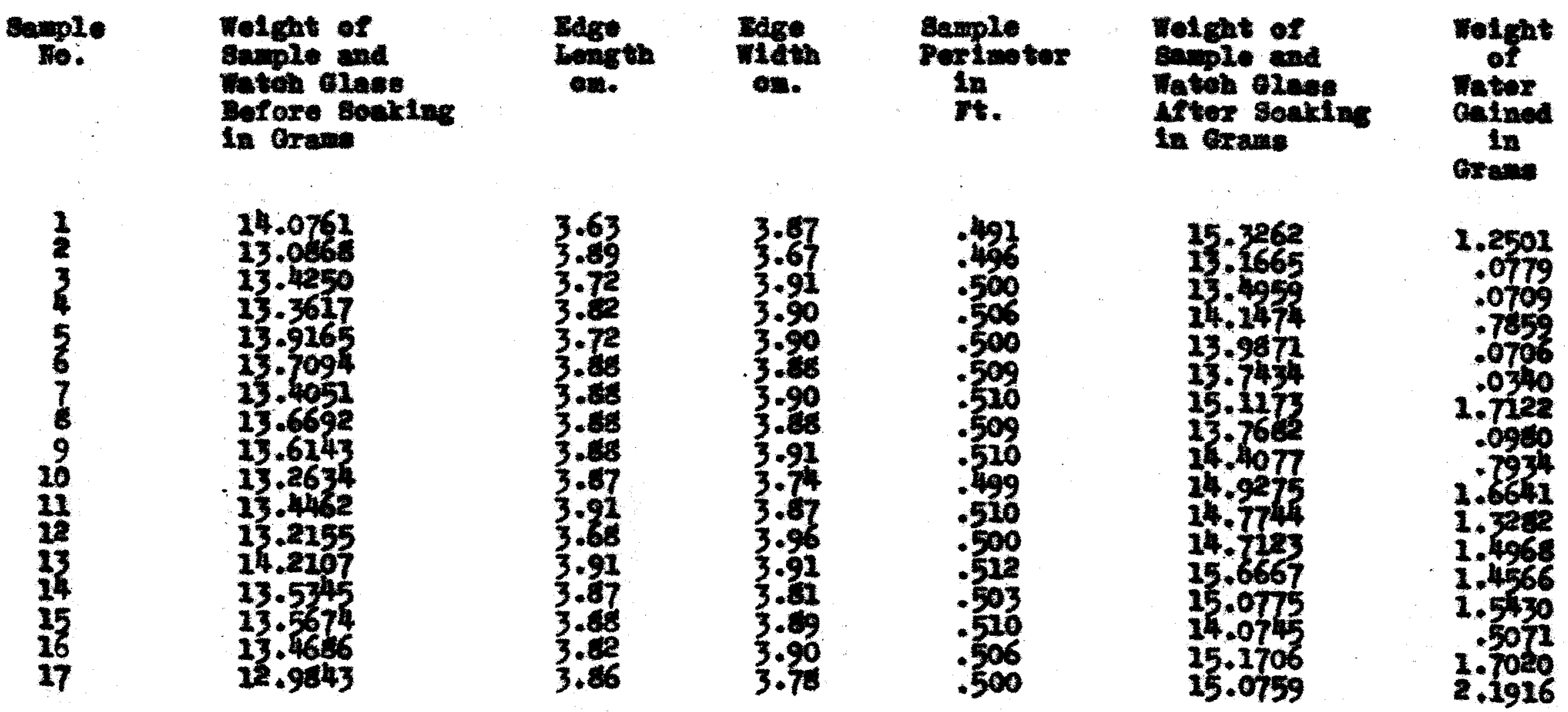


APPEDTX B - 00NT ITUED

DRTIMe DAFA FOR WATER IMATRamD MOISTURE BARRIERS - GROUP D

Nolght of samples and Watoh olase in Gxans

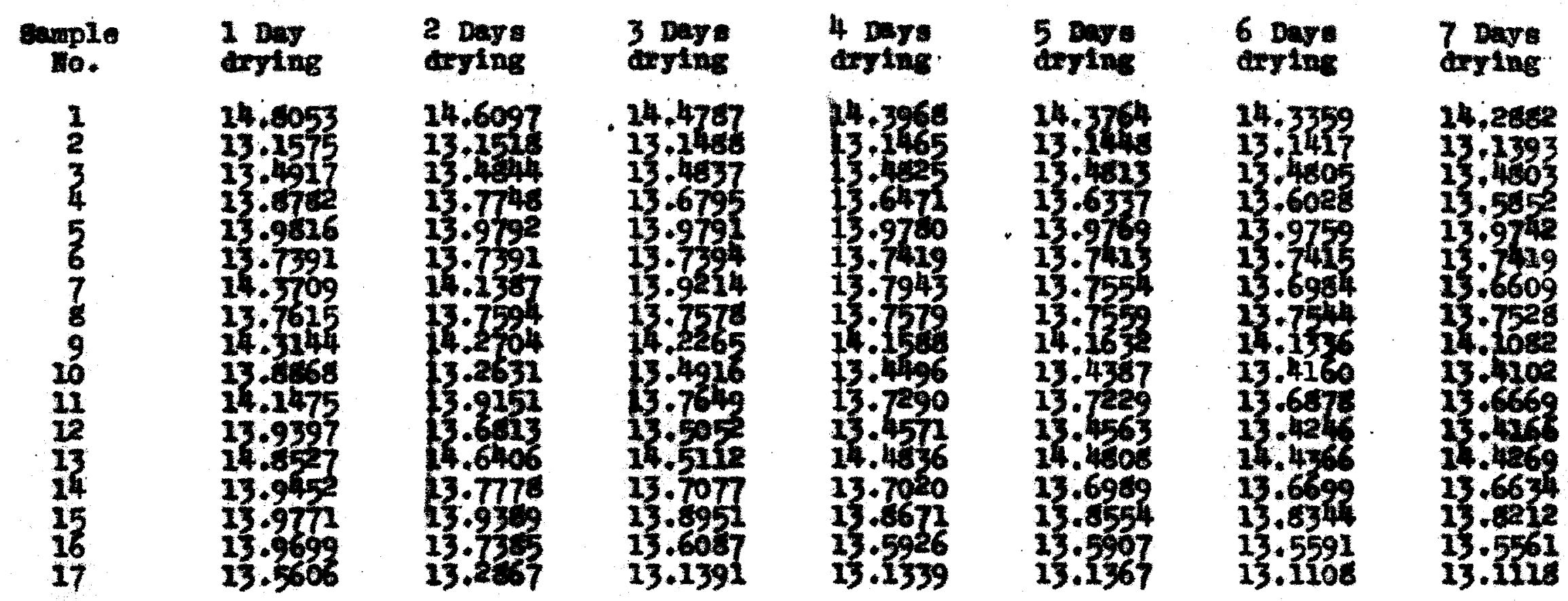




\section{APPEATI B - OONTIMUED}

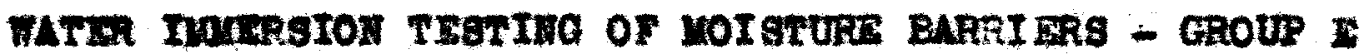

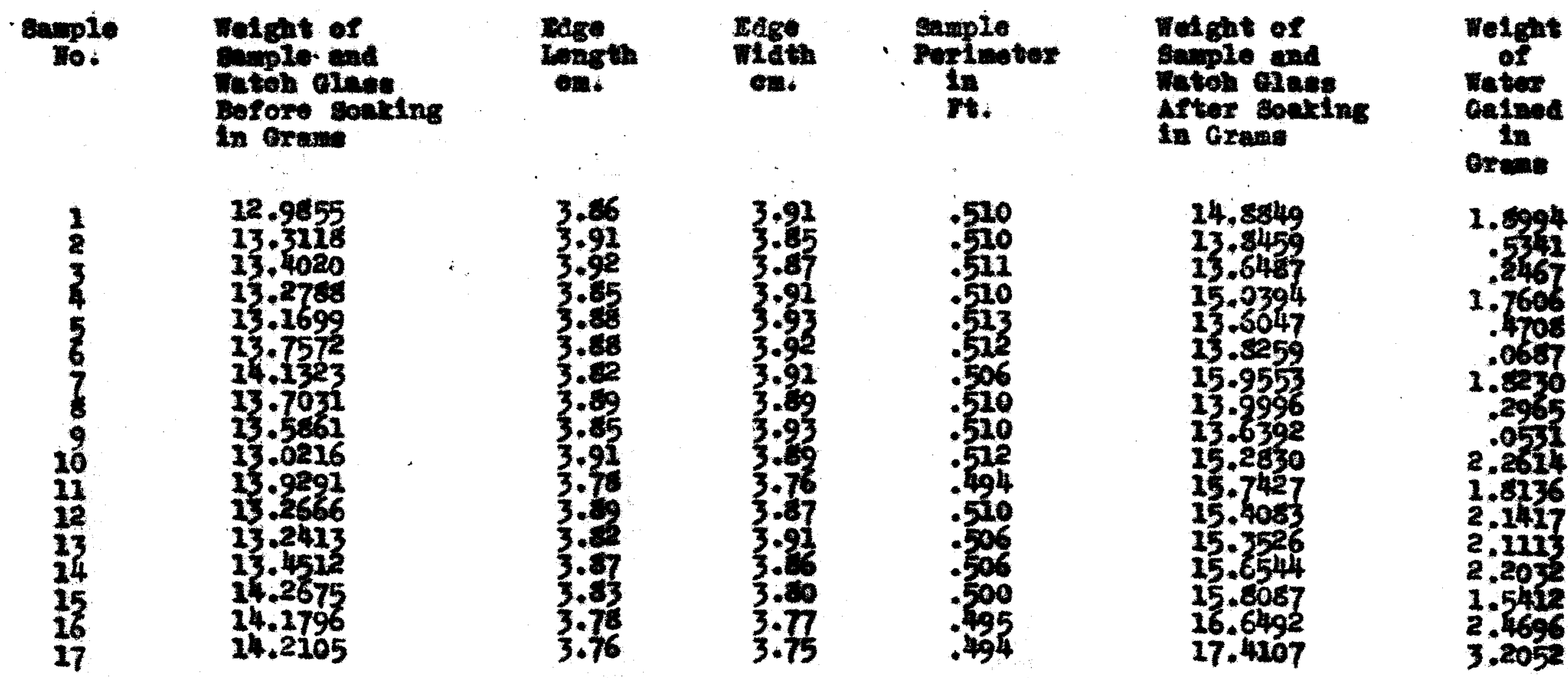


APPEDXX B - COATIUEED

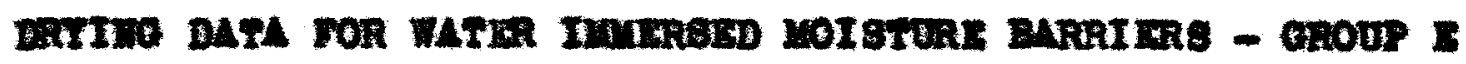

Woleht of sampies and wateh olase in Gran

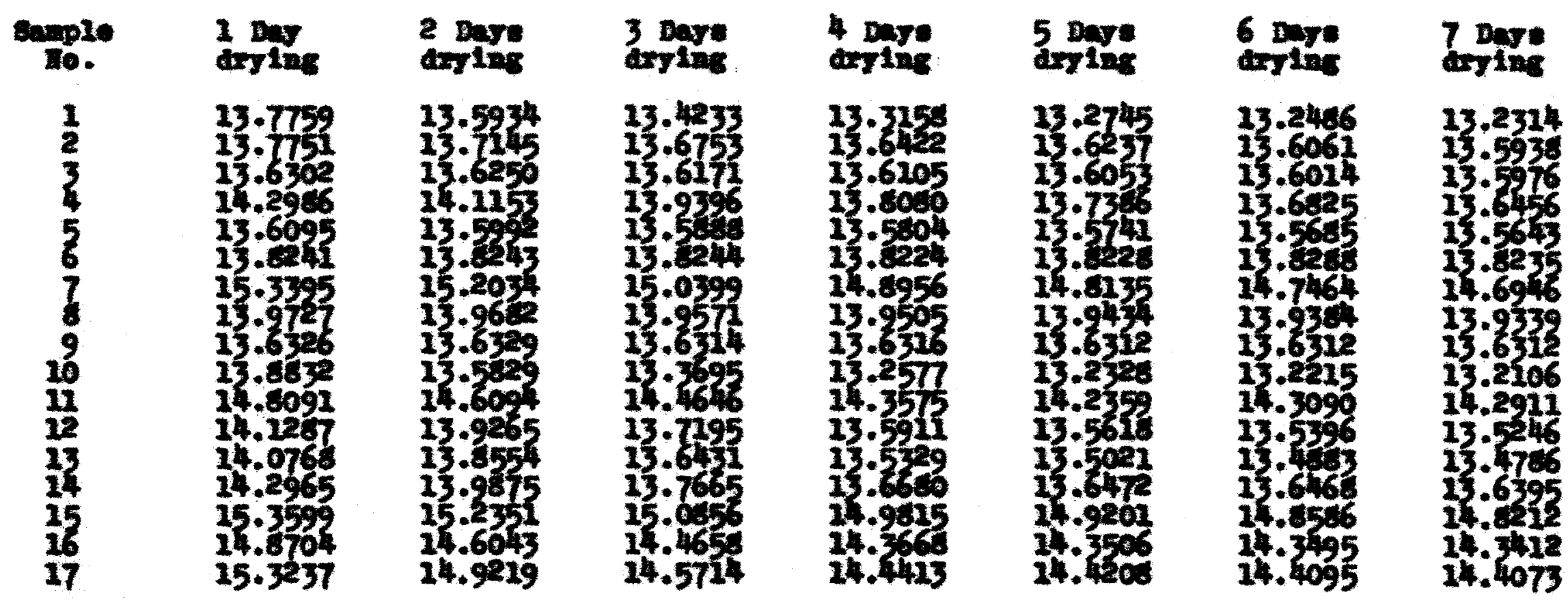


ARATIX B - OOFTIUUD

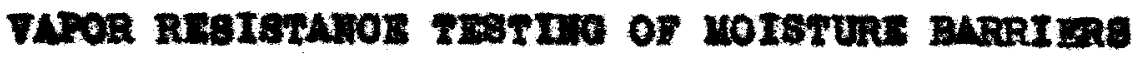

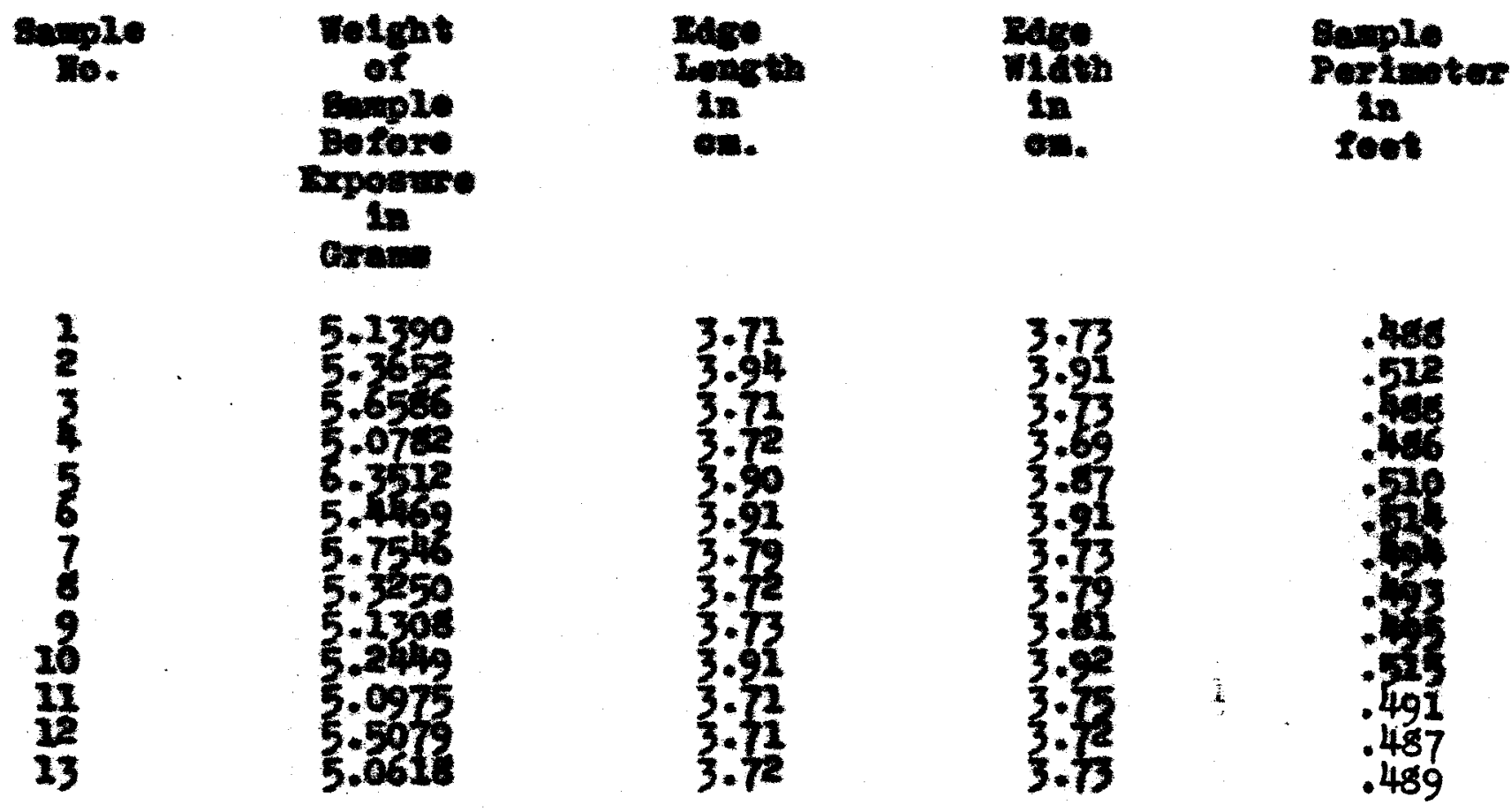


APPRADE B - comtrum

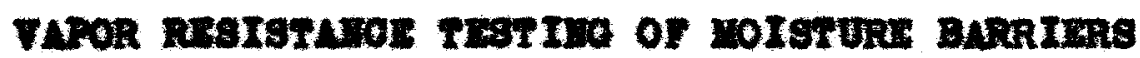

Wolght of Saple Eoh Day Daring Tenting in Gram

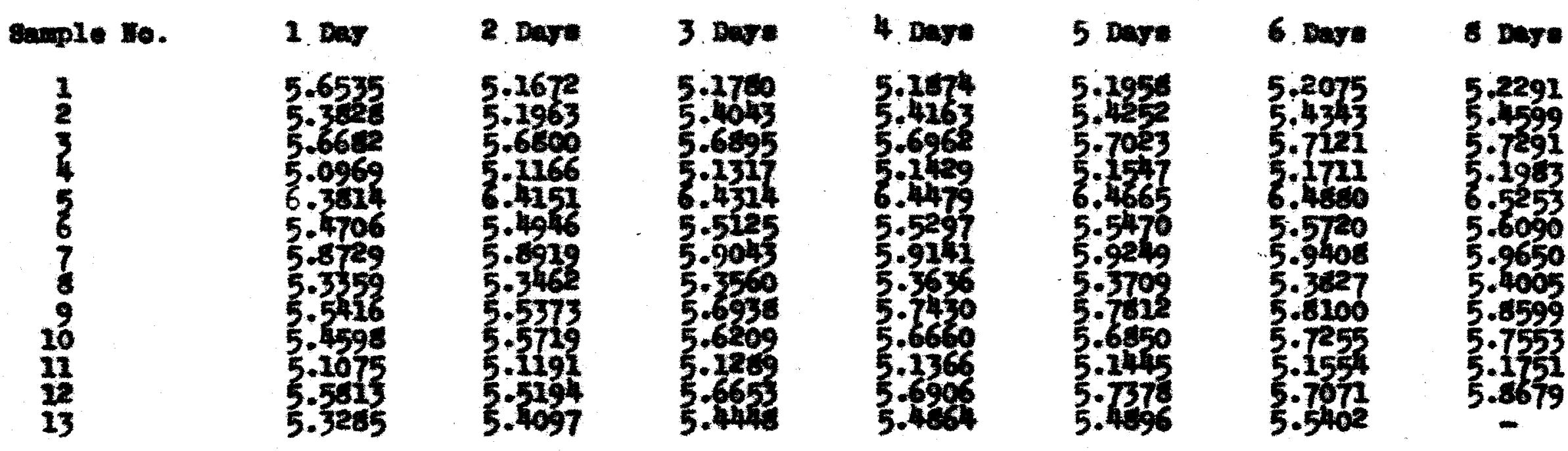


APPIADIX B - CONTIWUED

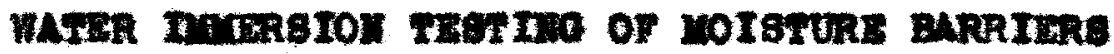

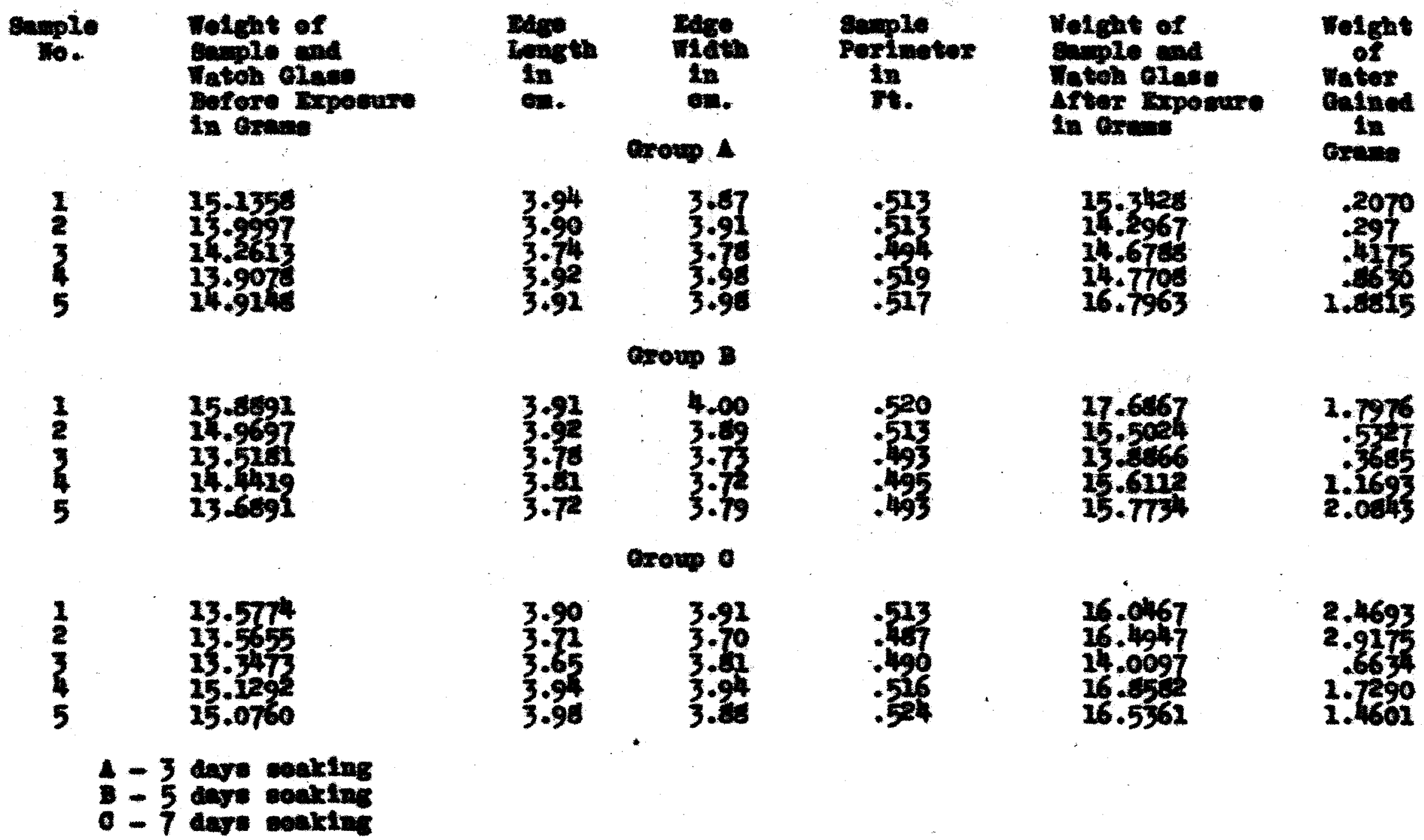

8 
APPANDIX B - CONT IHURD

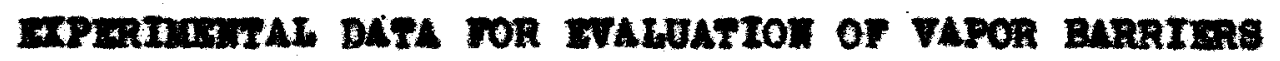

Wolght of Bamplos and Woighing Dottles in aram

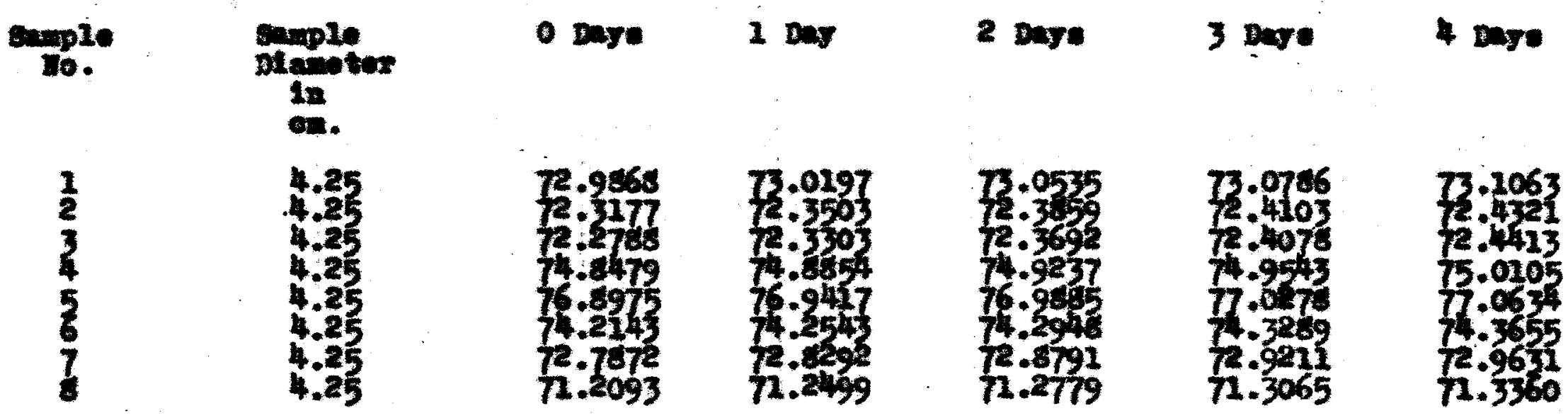


APPADEX - comrrum

Wotght of enples and Weighing Dottloe in Gxano

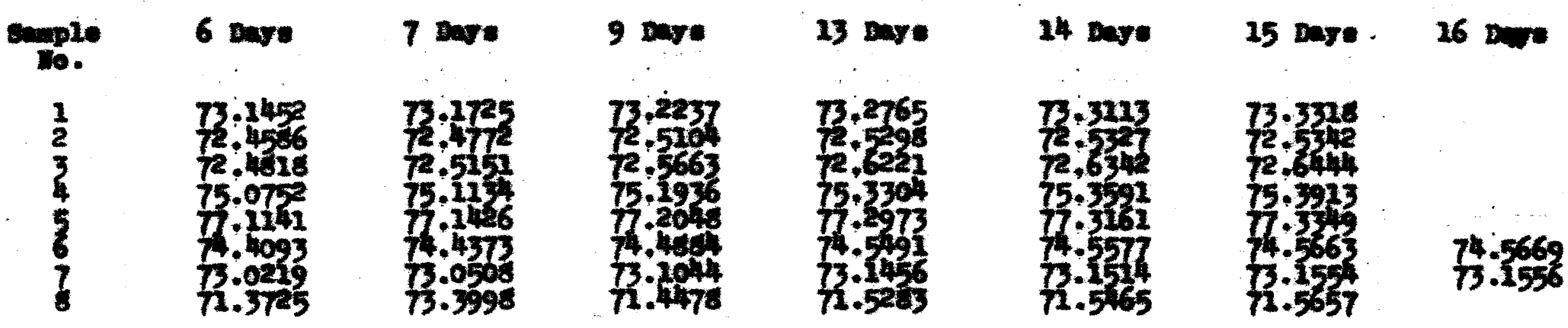




\section{VIT4}

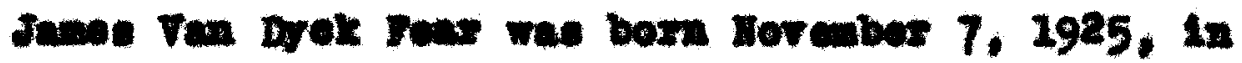

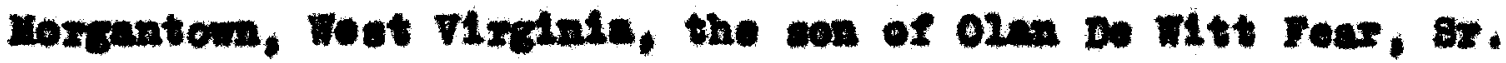

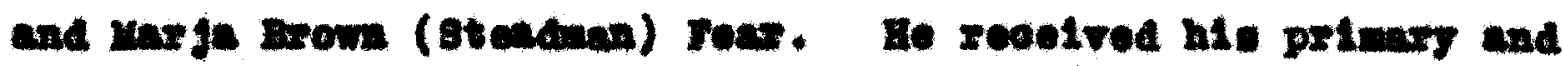

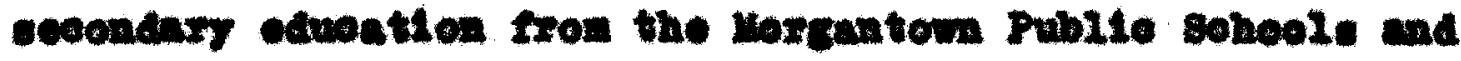

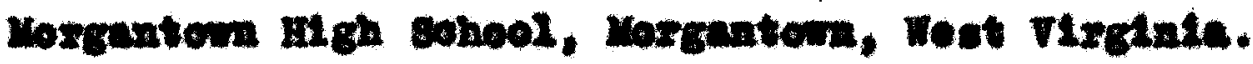

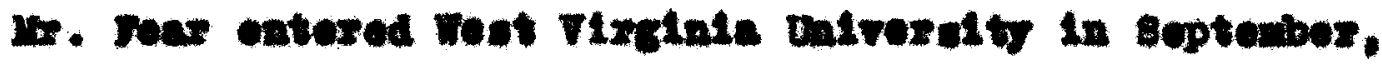
1942, and in Juty, 1943, the Butrenet by of louteri11, from

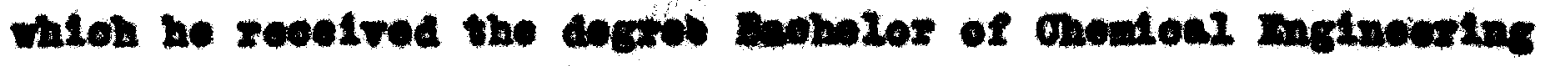
in sur. 1945.

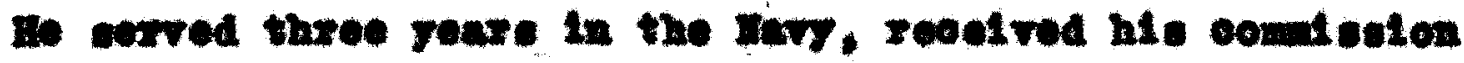

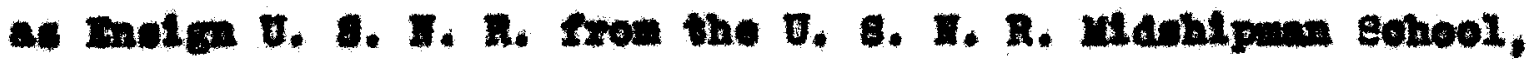

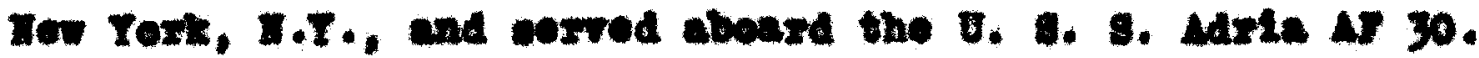

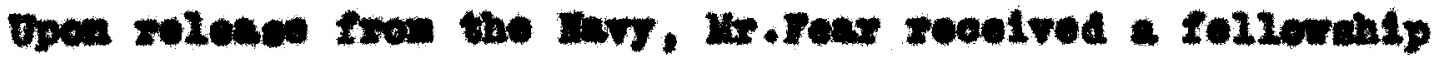
Wth the ontrexatis of loul wille Inotitute of Inematria Rosarroh. In obtalnod the degros of moter of Oncaleal Inclaeextas in septomber, 1947. 